NBSIR 75.691

\title{
A Characterization and Analysis of NBS Corridor Fire Experiments in Order to Evaluate the Behavior and Performance of Floor Covering Materials
}

James G. Quintiere

Center for Fire Research

Institute for Applied Technology

National Bureau of Standards

Washington, D. C. 20234

June 1975

Final Report

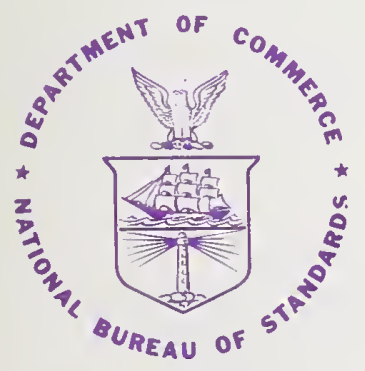

U.S, DEPARTMENT OF COMMERCE

NATIONAL BUREAU OF STANDARDS 


\section{Errata Sheet}

for:

NBSIR 75-691

entitled:

"A Characterization and Analysis of NBS Corridor Fire Experiments in Order to Evaluate the Behavior and Performance of Floor Covering Materials"

by: James G. Quintiere

dated: June 1975

Please make the following correction:

Page 18, Table 4, Column 9,

last line changed from 0.36 to 0.73 . 
NBSIR 75-691
A CHARACTERIZATION AND ANALYSIS OF NBS CORRIDOR FIRE EXPERIMENTS IN ORDER TO EVALUATE THE BEHAVIOR AND PERFORMANCE OF FLOOR COVERING MATERIALS

James G. Quintiere

Center for Fire Research Institute for Applied Technology National Bureau of Standards Washington, D. C. 20234

June 1975

Final Report

U.S. DEPARTMENT OF COMMERCE, Rogers C.B. Morton، Secretary NATIONAL BUREAU OF STANDARDS. Richard W. Roberts. Director 
LIST OF FIGURES . . . . . . . . . . . . . iv iv

1. INTRODUCTION AND REVIEW . . . . . . . . . . . . 1

2. INSTRUMENTATION AND SYSTEM DESCRIPTIONS . . . . . . 6

3. QUALITATIVE DESCRIPTION OF FIRE PROPAGATION OVER A FLOOR COVERING IN THE NBS CORRIDOR. . . . . . . .

4. QUANTITATIVE DESCRIPTION OF FACTORS INFLUENCING FIRE PROPAGATION . . . . . . . . . . . . . . 9

4.1. Crib Burning Rate.............. 10

4.2. Flame Spread. . . . . . . . . . . 10

4.3. Burn Area .. . . . . . . . . . . . 11

4.4. Energy Contribution of the Floor Covering Material. 12

4.5. Heating Characteristics of the Floor Coverings. . . 12

4.6. Radiant Heat Flux to the Floor Covering . . . . . 14

4.7. Ventilation Effects............ 15

5. SUMMARY AND CONCLUSIONS ............. . . 17

6. REFERENCES . . . . . . . . . . . . . 19

APPENDIX A. RESULTS OF CARPET FIRE EXPERIMENTS IN A CORRIDOR BY IITRI . . . . . . . . . . . . . . . . . . Appendix A-1. Letter from Bill Segall, Carpet and Rug

Institute ............... . Appendix A-2. Excerpt from IITRI Report to CRI . . . . Appendix A-3. An Analysis of an IITRI/CRI Floor Covering

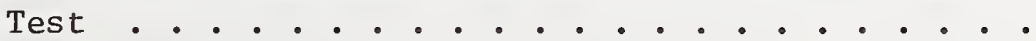

APPENDIX B. ESTIMATE OF THE ENERGY RELEASE RATE PER UNIT AREA FOR THE FLOOR COVERING MATERIALS . . . . . . .

APPENDIX C. COMPLETE RADIATION MODEL FOR DETERMINING FLUX TO FLOOR ELEMENT BASED UPON WALL AND CEILING SURFACE

TEMPERATURES . . . . . . . . . . . . . .

APPENDIX D. SI CONVERSION UNITS. . . . . . . . . . 


\section{LIST OF FIGURES}

Figure A-1. Results from IITRI-CRI corridor carpet burn experiments (CRI 70-010, carpet No. 28, propane gas room fire of $125,000 \mathrm{Btu} / \mathrm{min})$.

Figure 1. NBS corridor facility. $(1 \mathrm{ft}=0.3048 \mathrm{~m})$

Figure 2a. Crib weight loss (experiment 346).

$(1 \mathrm{lb}=0.4536 \mathrm{~kg})$

Figure 2b. Crib weight loss (experiment 347).

$(1 \mathrm{lb}=0.4536 \mathrm{~kg})$

Figure 2c. Crib weight loss (experiment 348).

( $1 \mathrm{lb}=0.4536 \mathrm{~kg}$ )

Figure 2d. Crib weight loss (experiment 349).

( $1 \mathrm{lb}=0.4536 \mathrm{~kg}$ )

Figure 3a. Corridor flame spread (experiment 347).

(1 $\mathrm{ft}=0.3045 \mathrm{~m})$

Figure 3b. Corridor flame spread (experiment 348).

$(1 \mathrm{ft}=0.3048 \mathrm{~m})$

Figure 3c. Corridor flame spread (experiment 349). (1 $\mathrm{ft}=0.3048 \mathrm{~m})$

Figure 4a. Floor thermocouple locations and path of flame spread. ( $1 \mathrm{ft}=0.3048 \mathrm{~m})$

Figure 4b. Floor flame spread velocity. (1 ft $=0.3048 \mathrm{~m})$

Figure 5a. Burn and char area with $\mathrm{HCl}_{\text {concentration }}$ (experiment 346$).\left(1 \mathrm{ft}^{2}=0.0929 \mathrm{~m}^{2}\right)$

Figure 5b. Burn area (experiment 347). (1 $\left.\mathrm{ft}^{2}=0.0929 \mathrm{~m}^{2}\right)$

Figure 5c. Burn area (experiment 348). $\left(1 \mathrm{ft}^{2}=0.0929 \mathrm{~m}^{2}\right)$

Figure 5d. Burn area (experiment 349). $\left(1 \mathrm{ft}^{2}=0.0929 \mathrm{~m}^{2}\right)$

Figure 6a. Energy release rate (experiment 347$)$. (1 Btu/min $=17.57 \mathrm{~W}$ )

Figure 6b. Energy release rate (experiment 348$).(1 \mathrm{Btu} / \mathrm{min}=17.57 \mathrm{~W})$

Figure 6c. Energy release rate (experiment 347$).(1 \mathrm{Btu} / \mathrm{min}=17.57 \mathrm{~W}$ )

Figure 7. Combustion products temperature at locations downstream of fire (experiment 346). 
Figure 8a. Crib weight loss rate compared with corridor gas temperature at $X=4 \mathrm{ft}, Y=10 \mathrm{ft}, \mathrm{Z}=7 \mathrm{ft} 11$ in (experiment 346 ). ( $1 \mathrm{lb} / \mathrm{s}=0.4536 \mathrm{~kg} / \mathrm{s}, 1 \mathrm{ft}=0.3048 \mathrm{~m}, 1$ in $=0.054 \mathrm{~m}$ )

Figure 8b. Crib weight loss rate, gas temperature ( $X=4 \mathrm{ft}, \underline{Y}=10 \mathrm{ft}$, $\mathrm{Z}=7 \mathrm{ft} 11 \mathrm{in}$ ), and burn area (experiment 347).

$\left(1 \mathrm{lb} / \mathrm{s}=0.4536 \mathrm{~kg} / \mathrm{s}, 1 \mathrm{ft}^{2}=0.0929 \mathrm{~m}^{2}, 1 \mathrm{ft}=0.3048 \mathrm{~m}\right.$, 1 in $=0.0254 \mathrm{~m}$ )

Figure 8c. Crib weight loss rate, gas temperature ( $\mathrm{C}=4 \mathrm{ft}, \mathrm{Y}=10 \mathrm{ft}$, $\mathrm{Z}=7 \mathrm{ft} 11 \mathrm{in}$ ), and burn area (experiment 348).

$\left(1 \mathrm{lb} / \mathrm{s}=0.4536 \mathrm{~kg} / \mathrm{s}, 1 \mathrm{ft}^{2}=0.0929 \mathrm{~m}^{2}, 1 \mathrm{ft}=0.3048 \mathrm{~m}\right.$, 1 in $=0.0254 \mathrm{~m}$ )

Figure 8d. Corridor gas temperatures 1 inch $(2.54 \mathrm{~cm})$ below the ceiling at $\mathrm{Y}=10 \mathrm{ft}(3.05 \mathrm{~m})$ and $\mathrm{Y}=20 \mathrm{ft}(6.1 \mathrm{~m})$ (experiment 349 ).

Figure 9a. Floor surface temperature $2 \mathrm{ft}(0.61 \mathrm{~m})$ from doorway (experiment 346).

Figure 9b. Floor surface temperature $0.5 \mathrm{ft}(0.15 \mathrm{~m})$ from doorway (experiment 347).

Figure 9c. Floor surface temperature $0.5 \mathrm{ft}(0.15 \mathrm{~m})$ from doorway (experiment 348).

Figure 9d. Floor surface temperature $0.5 \mathrm{ft}(0.15 \mathrm{~m})$ from doorway (experiment 349).

Figure 10a. Corridor floor surface temperature at $Y=6 \mathrm{ft}(1.8 \mathrm{~m})$ (experiment 346).

Figure 10b. Corridor floor surface temperature at $Y=6 \mathrm{ft}(1.8 \mathrm{~m})$ (experiment 347).

Figure 10c. Corridor floor surface temperature at $Y=6 \mathrm{ft}(1.8 \mathrm{~m})$ (experiment 348).

Figure 10d. Corridor floor surface temperautre at $Y=6 \mathrm{ft}(1.8 \mathrm{~m})$ (experiment 349).

Figure 1la. Floor surface temperature distribution (open and black symbols refer to two independent measurements at the same location) (experiment 346$).(1 \mathrm{ft}=0.3048 \mathrm{~m})$

Figure 11b. Floor surface temperature distribution (experiment 347 ). $(1 \mathrm{ft}=0.3048 \mathrm{~m})$ 


\section{LIST OF FIGURES (cont'd)}

Figure 11c. Floor surface temperature distribution (experiment 348 ). ( $1 \mathrm{ft}=0.3048 \mathrm{~m})$

Figure 11d. Floor surface temperature distribution (experiment 349). $(1 \mathrm{ft}=0.3048 \mathrm{~m})$

Figure 12. Fraction of radiant energy transmitted through a sapphire window from a blackbody source.

Figure 13a. Incident radiant heat flux to floor (experiment 346) (1 ft $=0.3048 \mathrm{~m}$ )

Figure 13b. Incident radiant heat flux to floor (experiment 348). $(1 \mathrm{ft}=0.3048 \mathrm{~m})$

Figure 13c. Incident radiant heat flux to floor (experiment 349). $(1 \mathrm{ft}=0.3048 \mathrm{~m})$

Figure 14a. Exit velocities at doorway (experiment 346). (1 $\mathrm{ft} / \mathrm{min}=0.00508 \mathrm{~m} / \mathrm{s}$ )

Figure 14b. Exit velocities at doorway (experiment 348). $(1 \mathrm{ft} / \mathrm{min}=0.00508 \mathrm{~m} / \mathrm{s}$ )

Figure 14c. Exit and inflow velocities at doorway (experiment 349). (1 $\mathrm{ft} / \mathrm{min}=0.00508 \mathrm{~m} / \mathrm{s}$ )

Figure 15a. Estimated fuel potential burning rate of room fire (experiment 346). (1 1b/min $=0.00756 \mathrm{~kg} / \mathrm{s})$

Figure 15b. Estimated fuel potential burning rate of room fire (experiment 348). (1 1b/min $=0.00756 \mathrm{~kg} / \mathrm{s})$

Figure 15c. Estimated fuel potential burning rate of room fire (experiment 349). (1 1b/min $=0.00756 \mathrm{~kg} / \mathrm{s})$ 
A CHARACTERIZATION AND ANALYSIS OF NBS CORRIDOR FIRE EXPERIMENTS IN ORDER TO EVALUATE THE BEHAVIOR AND PERFORMANCE.

OF FLOOR COVERING MATERIALS

James G. Quintiere

\begin{abstract}
Data is presented for four fire experiments which examine the fire propagation from a room fire to a floor covering material in a corridor. The four floor covering materials include a nylon and an olefin carpet, vinyl sheet, and red oak flooring. Limited flame spread occurred for the vinyl sheet material; however, the three other materials involved full fire propagation in the corridor. The data are analyzed to examine the factors influencing fire propagation. Included in this analysis is the rate of energy contribution from the room fire and floor covering material, the rate of flame spread, heat transfer to the floor covering, and flow interactions between the room and corridor. A review of previous related experiments is also presented.
\end{abstract}

Key words: Corridor fire spread; energy release rate; fire induced flow; flame propagation; flashover; floor coverings; radiant heat flux.

\title{
1. INTRODUCTION AND REVIEW
}

A need exists to develop a laboratory test method which can measure the flammability performance of floor covering materials. Within the limits of our present understanding, this method must be capable of measuring the relevant parameters of the potential hazard associated with building fires. One special aspect is the spread of fires through corridors in which the floor material is the primary combustible lining. Such an arrangement has been the focus of investigation in the NBS corridor fire experiments. From the results of these experiments and analysis thereof, we wish to determine quantitatively the role of floor covering materials with regard to fire propagation and energy release rate. In addition, we seek to characterize the interaction between the room fire and the spread of fire to the corridor. The potential hazard associated with smoke deve1opment is not examined in this study.

The results of NBS corridor fire experiments involving a number of floor covering materials have been presented by Fung, Suchome1, and Oglesby $[1]^{1}$. They report: (1) the primary hazard is rapid flame spread from the burn room down the length of the corridor; (2) most of the energy released in the room is transferred into the corridor by radiation and convection; (3) radiant preheating of the floor covering prior to rapid flame spread is the dominant mode of heat transfer; (4) after flashover the energy

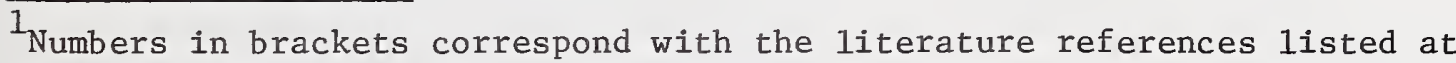
the end of this paper. 
release rate of the floor covering can exceed $100,000 \mathrm{Btu} / \mathrm{min} .^{2}$ In their report, floor covering materials are ranked in performance by calculating the time integral of energy input rate to the corridor up to the onset of full corridor involvement. Also presented in their report is a flame spread analysis based on radiant preheating of the floor covering.

Based on the data from these experiments a summary of conditions and results has been tabulated in tables $1 \mathrm{a}$ and $1 \mathrm{~b}$. Omitted information is either inaccessible or not available. The weight loss behavior, for one of the four ignited cribs, was represented by two parameters - time to achieve steady burning and burning rate. Since the burning rate is generally unsteady, these parameters must be selected with some degree of arbitrariness. In these experiments it seemed appropriate to select the time factor as the time at which $5 \%$ of the crib was consumed, $t_{5 \%}$. The average burning rate was then chosen as the change in crib mass between $t_{5 \%}$ and flashover occurred divided by the time between these events. Flashover time was taken at the instant of rapid flame spread in the corridor. It was based on a rapid increase in the temperature by the thermocouples located on the surface of the floor covering material. Flashover is defined in this paper as a sudden rise in the gas temperature followed by rapid flame spread.

The character of the NBS corridor fires has been either rapid flame spread along the length of the corridor space or an unsustained flame spread several feet beyond the burn room doorway. The former characterization has been the prevailing one for this series of experiments. Two situations occurred which do not fit clearly into either of these two modes of characterization. In test 336 (viny1 asbestos tile) two local flashovers occurred. The first occurred at 520 seconds and flame spread on the floor from 5 to 10 feet in 9 seconds; the second occurred at 1,020 seconds with final flame spread to 15 or 20 feet. The fire was extinguished at 1,080 seconds. Finally, in test 337, a flashover occurred at 420 seconds, however, subsequent flame spread did not go beyond 15 feet.

Because flashover was a prevalent mode of behavior in these experiments, flashover time is an obvious criterion for ranking material performance. Alternative criteria might be an adjusted flashover time (flashover time minus $t_{5 \%}$ ), or the energy criterion used in reference [1]. Time to flashover is probably the most accurately determined quantity of these criteria. It was compared to the results of several standard and proposed flame spread test methods. The results were presented and discussed by Quintiere and Huggett [2]. It is shown in that report that good correlation resulted between any flame spread test method and these corridor fire experiments.

Corridor experiments involving other carpet materials were performed by Illinois Institute of Technology Research Institute (IITRI) under a slightly different arrangement. Although the severity of their room fires was greater than the NBS fires, no flashover or sustained propagation

${ }^{2}$ Conversion factors from units used in this report to SI units are given in appendix $\mathrm{D}$. 


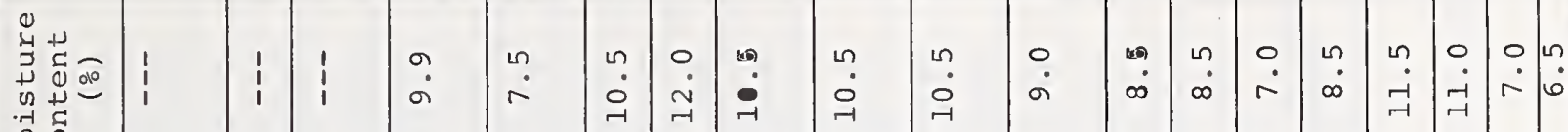
$\sum^{-1} \tilde{U}^{\circ}$

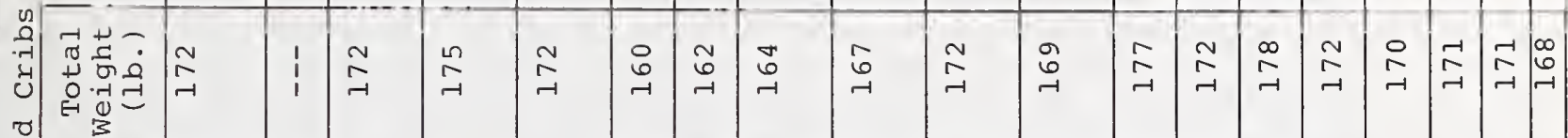
r

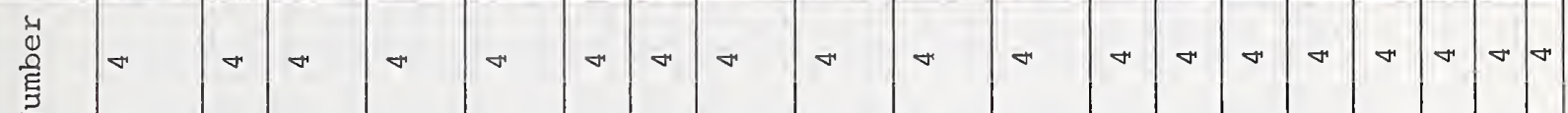
ֻุ.

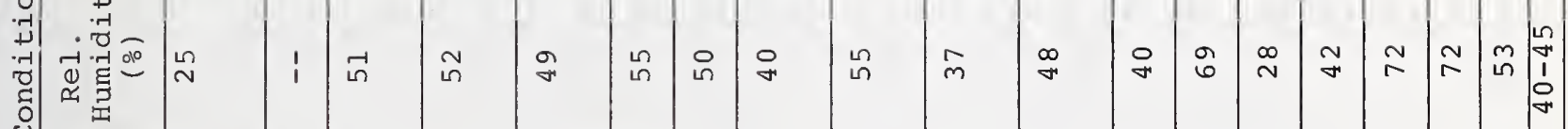

द

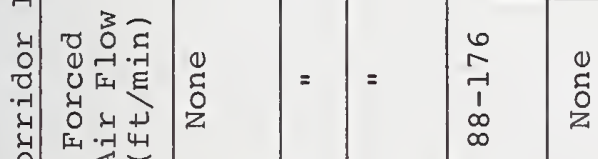

U⿺辶寸

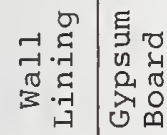

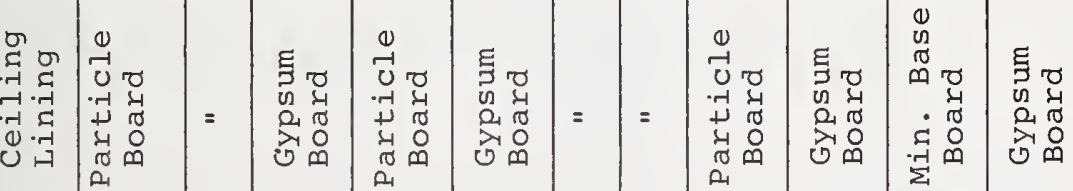

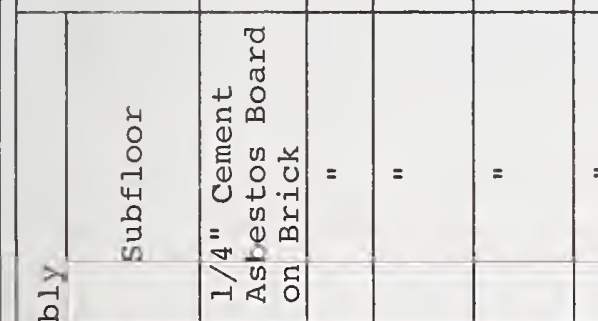

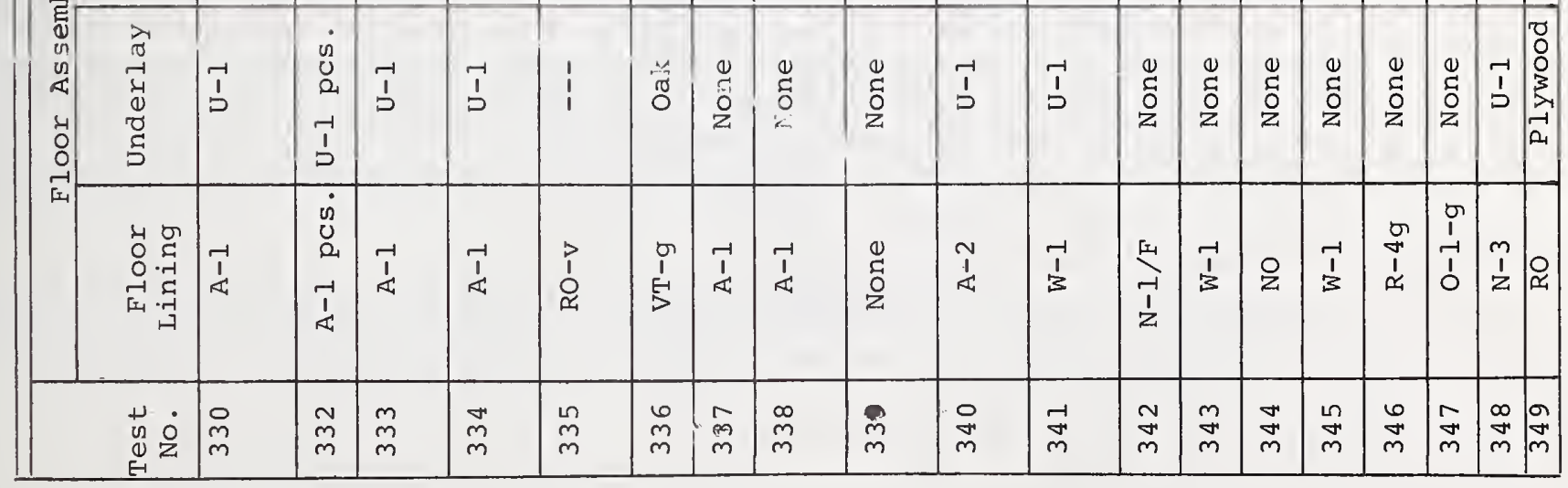




\begin{tabular}{|c|c|c|c|c|c|c|c|c|c|c|c|c|c|c|c|c|c|c|c|c|}
\hline \multirow{5}{*}{ 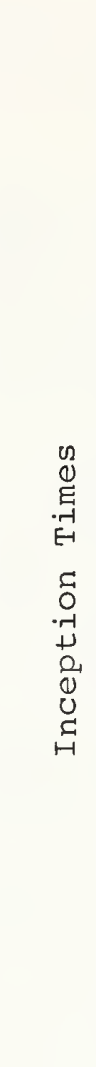 } & 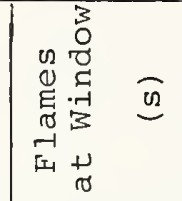 & $\stackrel{n}{n}$ & $\begin{array}{l}0 \\
0 \\
\text { in }\end{array}$ & $\stackrel{\circ}{\circ}$ & $\begin{array}{l}0 \\
6 \\
2\end{array}$ & $\begin{array}{l}0 \\
\text { m } \\
\text { in }\end{array}$ & 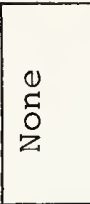 & \begin{tabular}{l}
0 \\
\multirow{0}{0}{} \\
0 \\
$z$
\end{tabular} & $\underset{\sim}{\stackrel{O}{v}}$ & 1 & $\stackrel{-1}{\sim}$ & $\begin{array}{l}0 \\
i n \\
\text { in }\end{array}$ & $\mid \begin{array}{c}-1 \\
\infty \\
m\end{array}$ & $\begin{array}{l}n \\
i n \\
m\end{array}$ & $\begin{array}{c}0 \\
+ \\
\infty\end{array}$ & $\stackrel{0}{\stackrel{2}{7}}$ & $\begin{array}{l}0 \\
0 \\
0 \\
z\end{array}$ & $\begin{array}{l}0 \\
0 \\
0 \\
-1\end{array}$ & O & $\begin{array}{l}0 \\
-1 \\
-1\end{array}$ \\
\hline & 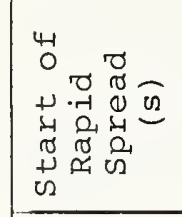 & i & $\begin{array}{l}1 \\
1 \\
1\end{array}$ & $\begin{array}{l}n \\
n \\
n\end{array}$ & $\begin{array}{l}1 \\
1 \\
1\end{array}$ & $\vec{\nabla}$ & 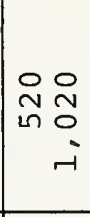 & 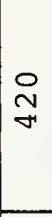 & $\begin{array}{l}1 \\
1 \\
1\end{array}$ & $\begin{array}{l}1 \\
1 \\
1\end{array}$ & $\underset{\sim}{\sim}$ & $\begin{array}{l}0 \\
6 \\
6\end{array}$ & O & $\begin{array}{c}N \\
-1 \\
m\end{array}$ & 呆 & $\underset{\sim}{\stackrel{O}{\sim}}$ & 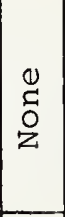 & $\begin{array}{c}0 \\
0 \\
\infty \\
1 \\
1 \\
0 \\
+ \\
\infty\end{array}$ & $\stackrel{O}{\stackrel{9}{*}}$ & $\begin{array}{l}\circ \\
\mathrm{m}\end{array}$ \\
\hline & 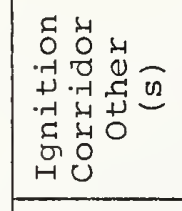 & 음 & $\stackrel{0}{\stackrel{9}{r}}$ & 1 & $\begin{array}{l}1 \\
1 \\
1\end{array}$ & $\begin{array}{l}1 \\
1 \\
1\end{array}$ & 1 & $\begin{array}{l}1 \\
1 \\
1\end{array}$ & $\begin{array}{l}1 \\
1 \\
1\end{array}$ & $\begin{array}{l}1 \\
1 \\
1\end{array}$ & $\begin{array}{l}1 \\
1\end{array}$ & $\begin{array}{l}1 \\
1 \\
1\end{array}$ & $\begin{array}{l}1 \\
1 \\
1\end{array}$ & $\begin{array}{l}1 \\
1 \\
1\end{array}$ & $\begin{array}{l}1 \\
1\end{array}$ & $\begin{array}{l}1 \\
1 \\
1\end{array}$ & $\begin{array}{l}1 \\
1 \\
1\end{array}$ & I & $\begin{array}{l}1 \\
1 \\
1\end{array}$ & $\begin{array}{l}1 \\
1 \\
1\end{array}$ \\
\hline & 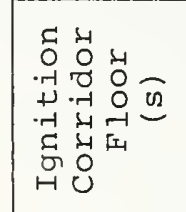 & $\begin{array}{l}n \\
\text { nn } \\
-1\end{array}$ & $\begin{array}{l}n \\
6 \\
6\end{array}$ & $\begin{array}{l}n \\
\stackrel{n}{0} \\
\gamma\end{array}$ & $\begin{array}{l}1 \\
1 \\
1\end{array}$ & 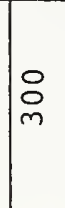 & $\begin{array}{l}n \\
r \\
7 \\
1 \\
0 \\
0 \\
m\end{array}$ & 웅 & 品 & $\begin{array}{l}1 \\
1 \\
1\end{array}$ & $\begin{array}{l}0 \\
m \\
m \\
1 \\
0 \\
0 \\
m\end{array}$ & $\begin{array}{l}n \\
-1 \\
m\end{array}$ & O̊ & O & $\begin{array}{l}0 \\
\infty \\
\infty\end{array}$ & $\begin{array}{l}1 \\
1 \\
1\end{array}$ & $\begin{array}{l}\circ \\
0 \\
\forall\end{array}$ & $\begin{array}{l}0 \\
\infty \\
\infty \\
m\end{array}$ & $\begin{array}{l}\omega \\
-1 \\
m\end{array}$ & 엄 \\
\hline & 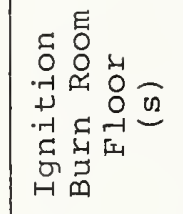 & $\begin{array}{l}1 \\
1 \\
1\end{array}$ & $\begin{array}{l}1 \\
1 \\
1\end{array}$ & 욤 & $\begin{array}{l}1 \\
1 \\
1\end{array}$ & $\begin{array}{l}1 \\
1 \\
1\end{array}$ & $\begin{array}{ll}1 & 1 \\
1 & 1\end{array}$ & $\begin{array}{l}1 \\
1 \\
1\end{array}$ & 1 & $\begin{array}{l}1 \\
1 \\
1\end{array}$ & i & $\begin{array}{l}\tilde{O} \\
\mathrm{O}\end{array}$ & $\mid \begin{array}{l}1 \\
1 \\
1\end{array}$ & $\begin{array}{l}0 \\
\text { N }\end{array}$ & $\begin{array}{l}0 \\
\infty \\
-1\end{array}$ & $\begin{array}{l}1 \\
1 \\
i\end{array}$ & O & $\stackrel{\circ}{m}$ & $\begin{array}{l}0 \\
\infty \\
\infty \\
-1\end{array}$ & $\stackrel{\circ}{\stackrel{\circ}{N}}$ \\
\hline \multirow{3}{*}{ 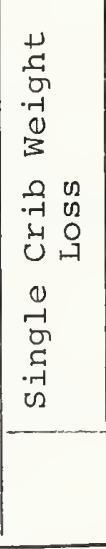 } & 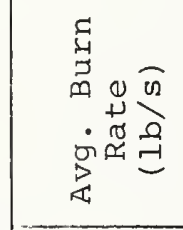 & $\begin{array}{l}1 \\
1 \\
1\end{array}$ & $\begin{array}{l}1 \\
1\end{array}$ & 1 & $\begin{array}{l}1 \\
1 \\
1\end{array}$ & $\mid \begin{array}{l}-1 \\
\vec{J} \\
0 \\
0\end{array}$ & \begin{tabular}{ll}
$\infty$ & 0 \\
\multirow{1}{*}{} & $m$ \\
0 & 0 \\
0 & 0
\end{tabular} & $\mid \begin{array}{l}N \\
m \\
0 \\
0 \\
0\end{array}$ & $\begin{array}{l}1 \\
1 \\
1\end{array}$ & \begin{tabular}{l}
0 \\
$m$ \\
\multirow{1}{*}{} \\
0 \\
0
\end{tabular} & $\begin{array}{l}n \\
m \\
0 \\
0\end{array}$ & $\begin{array}{l}0 \\
0 \\
0 \\
0\end{array}$ & $\begin{array}{l}\infty \\
m \\
0 \\
0 \\
0\end{array}$ & \begin{tabular}{l} 
Ln \\
\multirow{O}{0}{} \\
0 \\
0
\end{tabular} & $\begin{array}{l}\tilde{D} \\
2 \\
0 \\
0\end{array}$ & i & $\begin{array}{l}\vec{\sigma} \\
\vec{\sigma} \\
0\end{array}$ & $\begin{array}{l}\overrightarrow{-} \\
\vec{\sigma} \\
0 \\
0\end{array}$ & $\begin{array}{l}0 \\
\vec{\sigma} \\
0 \\
0 \\
0\end{array}$ & $\begin{array}{l}\infty \\
+ \\
0 \\
0\end{array}$ \\
\hline & 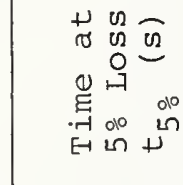 & I & $\begin{array}{l}1 \\
1 \\
1\end{array}$ & $\begin{array}{l}1 \\
1 \\
1\end{array}$ & $\begin{array}{l}1 \\
1 \\
1\end{array}$ & $\mid \begin{array}{l}0 \\
-1 \\
\sim\end{array}$ & ন্ & $\stackrel{\vec{m}}{\sim}$ & $\begin{array}{l}1 \\
1 \\
1\end{array}$ & $\stackrel{\sim}{N}$ & 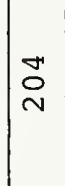 & 跙 & $\stackrel{\vec{m}}{\sim}$ & $\begin{array}{l}6 \\
\infty \\
-1\end{array}$ & 옥 & i & 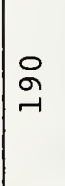 & 옥 & $\begin{array}{c}0 \\
0 \\
-1\end{array}$ & ᄋ \\
\hline & $\begin{array}{l}\Delta \\
0 \\
0 \\
0-1\end{array}$ & $\stackrel{\circ}{m}$ & $\stackrel{N}{\tilde{m}}$ & $\stackrel{m}{m}$ & 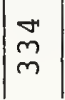 & $\begin{array}{l}m \\
m \\
m\end{array}$ & $\begin{array}{l}0 \\
m \\
m\end{array}$ & $\stackrel{\tilde{m}}{m}$ & $\begin{array}{l}\infty \\
m \\
m\end{array}$ & $\stackrel{\vec{m}}{m}$ & 울 & $\stackrel{-1}{\stackrel{-1}{m}}$ & $\underset{m}{\sim}$ & $\underset{m}{m}$ & $\underset{m}{\vec{m}}$ & $\stackrel{\sim}{\stackrel{m}{m}}$ & $\begin{array}{l}\sigma \\
\tilde{m}\end{array}$ & $\underset{m}{r}$ & $\begin{array}{l}\infty \\
\stackrel{\infty}{m}\end{array}$ & ga \\
\hline
\end{tabular}

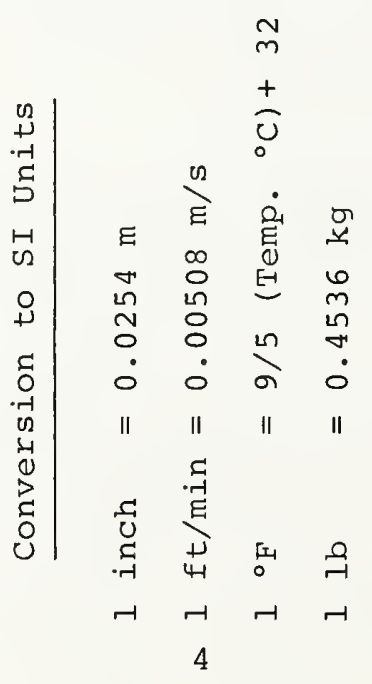


occurred in any of the IITRI experiments for carpets which passed the pill test. ${ }^{3}$ A summary of the IITRI work is contained in appendix A. Several reasons can be considered to explain the differences in corridor fire behavior between the NBS and IITRI experiments. First, the nature of materials tested could have differed considerably. Based on the description of the carpets tested by IITRI (a11 passed the pill test), no obvious differences can be attributed to carpets. However, IITRI does report that an earlier carpet corridor test with a carpet which failed the pill test did lead to a flashover behavior similar to that seen in the NBS experiments. Second, IITRI used propane gas as a primary fuel source with an energy equivalent rate of $125,000 \mathrm{Btu} / \mathrm{min}$ while NBS used wood cribs at a nominal energy release rate of $80,000 \mathrm{Btu} / \mathrm{min}$. A $3 \mathrm{ft} x 8 \mathrm{ft}$ section of floor covering material in the NBS burn room also contributed to the energy release into the corridor. However, it was estimated that the total rate of energy supply to the corridor was higher for the IITRI experiments. Third, the thermal characteristics of corridor construction material differed to some extent. NBS primarily used 5/8 inch gypsum board on steel studs backed by glass-fiber insulation for corridor walls and ceiling with a subfloor of $1 / 4$ inch asbestos cement board $\left(1301 \mathrm{~b} / \mathrm{ft}^{3}\right)$ over brick and sand. IITRI used a fire-brick type construction for its walls which was said to have been selected to match the thermal properties of a plaster wall. The floor was concrete and the ceiling was asbestos board. Results from IITRI corridor experiments shown in appendix A indicate steadily increasing gas exhaust temperatures at the corridor midlocation whereas the NBS corridor gas temperatures approach steady state in 6 to 10 minutes when not influenced by the floor covering fire. Also, the floor covering fire did not appear to have contributed to the exhaust gas temperature levels of the IITRI work. Either the carpet fires did not contribute a significant energy release rate, or the wall and ceiling construction of the IITRI corridor absorbed a significant quantity of heat and had a long time response. The steadily increasing gas temperatures tend to support this conclusion. Unfortunately, no wall or ceiling surface temperature data from the IITRI work is available to us. Fourth, room and corridor configuration differed between the NBS and IITRI tests. The IITRI corridor is $55 \mathrm{ft}$ long, $6 \mathrm{ft}$ wide, and $8 \mathrm{ft}$ high. The corridor "window" was the full corridor cross section, and the doorway to the burn room was $6 \mathrm{ft}$ wide and approximately 6-7 ft high. The burn room was $10 \mathrm{ft}$ $\mathrm{x} 15 \mathrm{ft} \times 8 \mathrm{ft}$ high. It appears that potentially more induced airflow was available to the corridor and room in the IITRI fires than the NBS fire experiments. For the case of no combustible corridor linings IITRI reports [3] an air inflow rate of $180 \mathrm{lb} / \mathrm{min}$ for a propane room fire of 125,000 $\mathrm{Btu} / \mathrm{min}$. Only $98 \mathrm{lb} / \mathrm{min}$ of air is required for complete stoichiometric combustion of this propane flow. Although airflow measurements are not available for their carpet experiments, it appears that they have a sufficient air supply to prevent fuel rich conditions from developing. It will later be shown that changes in flow conditions during the NBS fires lead to insufficient air in the burn room for complete combustion.

\footnotetext{
3DOC FF 1-70, Carpet and Rugs (Pill Test) Standard for the Surface Flammability of Carpets and Rugs.
} 
The effect of ventilation, i.e. induced airflow on fire propagation in corridors (and rooms), can be significant. Corridor experiments [4] in the second floor of an old school building with a corridor of $11 \mathrm{ft}$ width, 13 ft height, and $72 \mathrm{ft}$ length demonstrated the effect of airflow on fire spread. Two half-open windows (approximate opening $3 \mathrm{ft} \times 5 \mathrm{ft}$ ) provided ventilation; and two $250 \mathrm{lb}$ wood cribs provided a burning rate of 14 to 20 $1 \mathrm{~b} / \mathrm{min}$ after 11 minutes. In all three experiments investigating flame spread on wall materials (the floor was hard wood with the finish worn off), flashover occurred in 6 to 7 minutes and was characterized as rapid combustion of the hot pyrolysis products encountering sufficient air; yet, surface flame spread along the wall lining material was not extensive before flashover. Crib flaming was momentarily reduced following flashover, but then flaming was reestablished (for the wall lining as well as the cribs). Thus, the cribs appeared to have generated a steady fuel supply with insufficient airflow, and when the excess fuel in the exhaust products mixed with a sufficient amount of incoming air, gas phase propagation occurred.

Other relevant corridor fire experiments are those conducted by McGuire [5]. A full-scale test in a corridor $6 \mathrm{ft}$ wide, $8 \mathrm{ft}$ high, and 63 ft long with concrete block walls, an asbestos board ceiling and a cellulose triacetate carpet on a concrete subfloor resulted in a flame propagation of 40 feet. The carpet had a rating of 435 by ASTM E 162. The exhaust end of the corridor was closed at the lower half and smaller vents existed along the corridor walls, top and bottom of the back wall, and in the burn room. The burn room doorway was $6 \mathrm{ft}$ high and $3 \mathrm{ft} 4$ in wide. The fuel source was primarily nine $4 \mathrm{ft} \times 8 \mathrm{ft}$ fiber insulation boards stacked vertically in the room. This study concluded that floor coverings having an ASTM E 162 index of 220 and less made little contribution to indefinite fire propagation in these particular experiments. Corresponding threshold values were 130 for ceiling linings and 35 for wall linings.

The present report seeks to present the results of four NBS corridor fire experiments not previously presented. Its objective is to examine the role played by the floor covering material in these corridor fire experiments. The use of high speed data acquisition systems in these four experiments permitted a detailed examination of a considerable quantity of data. These experiments will now be described.

\section{INSTRUMENTATION AND SYSTEM DESCRIPTIONS}

The dimensions of corridor-room system are listed as follows:

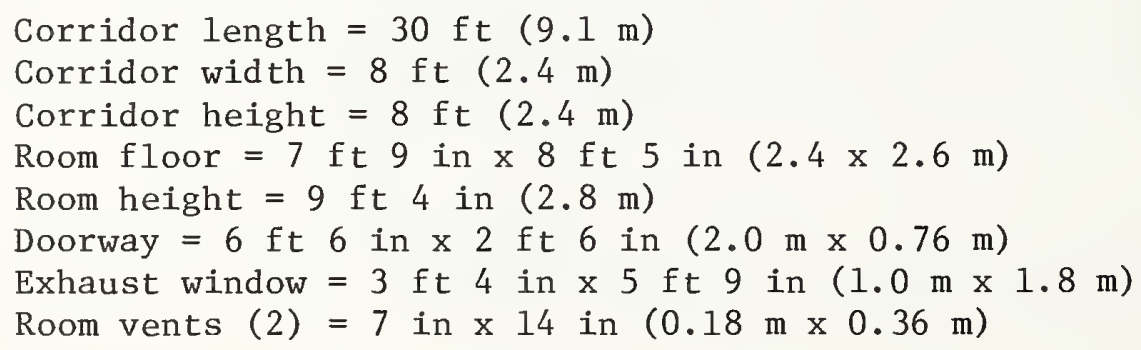


Data from as many as 60 thermocouples measuring gas and surface temperatures, five radiometers measuring corridor wall and floor incident radiant flux, assorted gas monitoring equipment, and pitot tubes at the window and doorway (measuring outflow at the top and inflow at the bottom) were recorded on a paper tape high speed data acquisition system at a scan rate of 9 channels per second. Up to twenty thermocouples monitoring floor flame spread and some gas monitoring equipment were recorded on a magnetic tape data system at a scan rate of 40 channels per second. The flame spread thermocouples were distributed to enable a record of the extent of area burning. The location of these thermocouples is shown in figure $4 \mathrm{a}$.

During tests 346-349 an effort was made to improve the quality of motion pictures taken of the fire development. In test 348, the view window facing the doorway was lowered to about 2 feet from the floor and heated with a hot air jet. This eliminated obscuration due to condensation of smoke particulates and permitted filming up to flashover. This was repeated in test 349 with an additional view window at the exhaust window at the end of the corridor. A time lapse camera set on automatic operation recorded events continuously at one frame per second up to 20 seconds before flashover. A third camera shot through the exhaust window as in previous tests. In these tests, observations on flame spread behavior were recorded.

In experiments (346-349), to be examined here, the following floor covering materials were used: vinyl sheet flooring, nylon and olefin carpets, and wood flooring. A description of these materials is given in table 2 .

\section{QUALITATIVE DESCRIPTION OF FIRE PROPAGATION OVER A FLOOR COVERING IN THE NBS CORRIDOR}

A qualitative description of fire propagation over a floor covering material in the NBS corridor will be presented. The more prevailing mode of propagation involving flashover followed by rapid flame spread will be considered. This description will be based upon visual observations recorded during the test and from the analysis of the test films. A schematic of the facility is shown in figure 1. Thus, a subjective interpretation of the fire behavior can be developed. A quantitative interpretation will follow in the next section. A description of test 349 -- red oak flooring -- will be presented.
$0-27 \mathrm{~s}$
Four wood cribs are ignited by pans containing heptane.

$60 \mathrm{~s}$ Smoke begins to exhaust from the burn room into corridor.
$170 \mathrm{~s}$ Smoke is darkening in the upper $1 / 3$ to $1 / 2$
Flames flicker to $3 \mathrm{ft}$ out of the doorway.
220 s Vapor evolving from floor in burn room and crib fires appear to be fully developed.
$240 \mathrm{~s} \quad$ Smoke is darker and fills the upper half of corridor; diffusing and settling to lower corridor half-space.
$245 \mathrm{~s}$ Ignition on the wood floor in burn room followed by rapid flame spread over this section of flooring. 
Table 2. Description of Flooring Materials

\begin{tabular}{|c|c|c|c|c|}
\hline Test No. & Floor Covering & Description & $\begin{array}{l}\text { Heat of } \\
\text { Combustion } \\
\text { (cal/g) }\end{array}$ & $\begin{array}{c}\text { Mass per } \\
\text { Unit Area } \\
\left(\mathrm{g} / \mathrm{cm}^{2}\right) \\
\end{array}$ \\
\hline 346 & $\begin{array}{l}\text { Vinyl Sheet } \\
(\mathrm{R}-4 \mathrm{~g})\end{array}$ & $\begin{array}{l}0.05 \text { inch vinyl } \\
\text { chips bonded to a } \\
0.04 \text { inch organic } \\
\text { felt backing. } \\
\text { Sheet was bonded } \\
\text { to an asbestos } \\
\text { cement board sub- } \\
\text { floor. }\end{array}$ & 2,970 & 0.315 \\
\hline 347 & $\begin{array}{l}\text { Olefin Carpet } \\
\quad(0-1 \mathrm{~g})\end{array}$ & $\begin{array}{l}\text { Level loop olefin } \\
\text { fiber with a poly- } \\
\text { propylene-jute } \\
\text { backing. Carpet was } \\
\text { bonded to an asbes- } \\
\text { tos cement board } \\
\text { subfloor. }\end{array}$ & 4,960 & 0.185 \\
\hline 348 & $\begin{array}{l}\text { Nylon Carpet } \\
(\mathrm{N}-3 / \mathrm{u})\end{array}$ & $\begin{array}{l}\text { Level loop nylon } \\
\text { with a jute-jute } \\
\text { backing. Carpet } \\
\text { laid on hair-jute } \\
\text { pad over asbestos } \\
\text { cement board sub- } \\
\text { floor. }\end{array}$ & 4,590 & 0.244 \\
\hline 349 & $\begin{array}{l}\text { Red Oak } \\
\text { Flooring } \\
\quad(\mathrm{RO})\end{array}$ & $\begin{array}{l}3 / 4 \text { inch tongue } \\
\text { and groove red oak } \\
\text { floor. Flooring } \\
\text { mounted on plywood } \\
\text { subfloor. }\end{array}$ & 4,460 & 1.27 \\
\hline
\end{tabular}

Higher heating value determined by the oxygen bomb method.

$$
\text { Conversion to SI units: } \begin{aligned}
1 \text { in } & =0.0254 \mathrm{~m} \\
& 1 \mathrm{cal} / \mathrm{g}=4,184 \mathrm{~J} / \mathrm{kg} \\
& 1 \mathrm{~g} / \mathrm{cm}^{2}=10 \mathrm{~kg} / \mathrm{m}^{2}
\end{aligned}
$$


$270 \mathrm{~s}$ Entire contents of the burn room are flaming; fire on floor is holding at the doorway.

275 s Grey smoke is obscurring all but lights in corridor.

$400 \mathrm{~s} \quad$ Floor fire has spread slowly into corridor about $1-1 / 2 \mathrm{ft}$ out of the doorway. Flames on the floor are leaning back toward the burn room due to the induced air current.

$450 \mathrm{~s}$ Visibility is increasing in lower half-space. Some burning and charring of paper is occuring on the gypsum board of the rear wall adjacent to doorway.

$487 \mathrm{~s} \quad$ Flame is beginning to spread along floor molding at base of rear wall toward the side wall.

$\sim 490 \mathrm{~s} \quad$ Flame has spread about $3 \mathrm{ft}$ out of the doorway and about $1 \mathrm{ft}$ to the right of the doorway. A strong effect of induced airflow is apparent on the leading edge of flame front.

$490 \mathrm{~s} \quad$ Apparent "fire whirl" or elongated flame occurs above the floor fire. Some flaming is visible along the base molding to left of the main flame area.

$527 \mathrm{~s} \quad$ Smoke is becoming black and dense over the upper corridor half-space.

$548 \mathrm{~s} \quad$ Flame has spread on floor $4 \mathrm{ft}$ out of the doorway and "fire whirls" are beginning to appear often with a duration of 1 to 3 seconds.

$582 \mathrm{~s} \quad$ Flame has spread to $6 \mathrm{ft}$ out of the doorway and a flame plume is developing over the central area reaching $3 \mathrm{ft}$ in height.

$600 \mathrm{~s}$ An increase in flame height is followed by darkening of the corridor space.

$635 \mathrm{~s}$ Flashover begins as the flames fill the rear of the corridor space.

$658 \mathrm{~s}$ Dense black smoke is exhausting from window.

$713 \mathrm{~s} \quad$ Flame propagation is nearing the exhaust window.

$717 \mathrm{~s} \quad$ Flames emerge from the window.

The fire was extinguished at $750 \mathrm{~s}$ and charring damage due to surface flame spread over the floor was extensive. Rapid fire propagation through the corridor appeared as a sheet of flames filling the corridor space behind it and flowing dense black smoke ahead of it. The average rate of propagation was about $20 \mathrm{ft} / \mathrm{min}$. When rapid flame spread began it was preceded by a localized flashover of the corridor space near the doorway. By appearance, this localized flashover took the form of the fire character changing from a creeping surface flame spread to a volume of flames filling the corridor space. The transition occurred in several seconds.

\section{QUANTITATIVE DESCRIPTION OF FACTORS INFLUENCING FIRE PROPAGATION}

The thermal measurements taken in tests No. 346-349 will be reviewed and analyzed. These measurements permit the estimation of flame spread rate, energy release rate, and incident radiation to the floor. In addition, they help to evaluate instrumentation performance. It should be 
pointed out that a complete set of data for test 347 could not be developed because of problems with the paper tape output.

\subsection{Crib Burning Rate}

One of four identical wood cribs was placed on a load cell platform and its weight loss was recorded. This crib was located in the center of the burn room floor with the other cribs located in each of the three corners of the room. The load cell response along with rate of weight loss is shown in figures $2 \mathrm{a}, \mathrm{b}, \mathrm{c}$, and d for experiments 346, 347, 348, and 349, respectively. In general, the load cell response is smooth, however, initial crib weight is not correctly indicated and sudden increases in weight are sometimes indicated. The first effect is probably due to improper setting of the initial tare weight, while the second effect may be due to a temperature increase of the load cell. More efficient cooling of the load cell would eliminate this problem. The relative weight loss changes are expected to be accurate and a smooth curve through the data points was used to determine the rate of weight loss. After 2 to 3 lbs of weight loss, the rate of weight loss tends to be fairly constant up to flashover or beyond. The maximum energy release rate of the four cribs is calculated based on the steady weight loss rate of one crib and a nominal heat of combustion of wood equal to $7,200 \mathrm{Btu} / \mathrm{lb}(4,000 \mathrm{cal} / \mathrm{g})$. This yields maximum energy release rates of 70,000 to $82,000 \mathrm{Btu} / \mathrm{min}$. Variations in the steady burning rate of the wood cribs indicate the extent of variation in reproducibility for wood crib fires. If the unmonitored wood cribs are unaffected by location, they may be expected to burn as the crib monitored by the load cell. Thus, it is reasonable to expect that all experiments had the same level of energy release rate from the crib fires (approximately 75,000 Btu/min). Before steady burning was attained it is not obvious from crib weight loss data whether the fire buildup rate was the same from four cribs for each experiment. The fire buildup period for the monitored crib varied from 100 to 400 seconds for these experiments. The reason for this time variation is not known.

\subsection{Flame Spread}

Flame spread over the floor covering material generally followed a path out of the burn room doorway then along the corridor. Initially, the flame progress from the doorway to the corridor centerline was slow; however, if flashover occurred a rapid flame spread would follow. The rate of flame spread was determined by the thermocouples placed in contact with the floor covering surface. As the flame reached the thermocouple, the surface, especially if it was a carpet, regressed away from the thermocouple. The thermocouple then measured a gas phase temperature between the surface and flame temperatures. In general, a rapid rise in temperature (e.g. $20{ }^{\circ} \mathrm{C} / \mathrm{s}$ ) or a temperature greater than $400^{\circ} \mathrm{C}$ was sufficient to indicate flaming at the thermocouple position. 
Surface flame spread results are shown in figures $3 a, b$, and $c$ for experiments 347, 348, and 349, respectively. On the curves, the horizontal line indicates the spread out of the doorway and at $Y=1.5 \mathrm{ft}$. Although a solid line indicates an average flame spread down the corridor, the initial spread rate is extremely rapid for the first $10 \mathrm{ft}$. Moreover, in test 347 an advancing sheet of flames filling the corridor crosssection appears to have led the surface flame spread as indicated by the thermocouples.

The rate of flame spread was computed based on a path of travel as shown in figure 4a. The results are shown in figure 4b. In all cases involving flashover the spread rate increased by a factor of 10 or more following flashover.

\subsection{Burn Area}

The area of the floor covering involved in burning gives an indication of the energy contribution of the floor covering. This was monitored during an experiment by 18 to 20 surface thermocouples along the floor. Each thermocouple was associated with an area with four thermocouples over the $24 \mathrm{ft}^{2}$ section of floor covering in the burn room and the remaining thermocouples distributed over increasing area sectors as distance increased from the doorway. Although ignition was easily discerned from thermocouple response, extinction was not as obvious. In most cases burning was continuous following ignition until water was applied to extinguish the fire. However, a steadily decreasing temperature response (following ignition) was adopted as a criterion for extinction of flaming.

The burning area curves are shown in figures 5a, b, c, and $d$. In figure $5 \mathrm{a}$, the results for vinyl sheet flooring indicate a relatively small area burned. Also, in this figure the utility of monitoring the area affected by the fire is demonstrated in interpreting other data. A temperature of $200{ }^{\circ} \mathrm{C}$ was used to indicate thermal decomposition of the vinyl sheet flooring. (Polyvinyl chloride decomposes between 200-300 ${ }^{\circ} \mathrm{C}$ ) [6]. HC1 measurements [7] associated with the decomposition of PVC are seen to follow a trend similar to the extent of "charring". In fact, from 600 to 1,200 seconds the HCl production rate is $10 \pm 1 \mathrm{ppm} / \mathrm{ft}^{2}$ of flooring which is above $200{ }^{\circ} \mathrm{C}$. Observations of the floor covering after test 346 indicated a burned area of $5 \mathrm{ft}^{2}$ in the corridor (in addition to the $24 \mathrm{ft}^{2}$ in the burn room) and a continuous char area of $20 \mathrm{ft}^{2}$ along with patches of char zones over another $20 \mathrm{ft}^{2}$. These observations are consistent with the areas determined by thermocouple analysis.

The results for tests 347 through 349 all involved flashover. In each case flashover occurred when approximately $15 \mathrm{ft}^{2}$ of corridor floor covering was burning. The nylon carpet in 348 did not burn the full corridor length although flames emerged from the exhaust window. Carpet samples taken from $Y=18 \mathrm{ft}$ and $\mathrm{Y}=21 \mathrm{ft}$ indicated melting, but no loss of weight. The thermocouple record of the nylon carpet surface at $\mathrm{Y}=21 \mathrm{ft}$ indicated that its temperature reached $220{ }^{\circ} \mathrm{C}$ corresponding to its melt temperature [7] at 588 seconds. Since this fire was extinguished at 600 seconds it appears that not much mass loss would occur in 12 seconds. 
Again, the thermocouple interpretation of the burning and phase change behavior of the floor covering materials appears to be reasonably in agreement with other observations and data.

\subsection{Energy Contribution of tine Floor Covering Material}

In evaluating the flammability hazard of floor covering materials, the significance of the energy release by that material must be considered. An attempt to estimate the energy release rate of the floor covering materials in experiments 346-349 was made. By estimating the energy release rate per unit surface area $\dot{E}_{F}^{\prime \prime}$, and knowing the area burning, $A_{b}$, the energy release rate could be determined. The energy release rate per unit area was estimated by using heats of combustion determined by an oxygen bomb calorimeter, mass measurements of the floor coverings, and duration of burning. This yields a maximum heat release rate which is consistent with the crib estimates. The details are presented in appendix $B$.

Figures $6 a, b$, and $c$ indicate energy release rates for floor covering and crib combustion. Experiment 346 is not displayed since the floor covering contributed a small amount of energy, i.e. a maximum release rate of 7,000 Btu/min. Although the energy release rate by the floor covering before flashover is about $15 \%$ of the crib release in experiment 347 , it is about $30 \%$ in experiments 348 and 349. Hence, the energy release by the floor covering can be a contributing factor in promoting flashover.

In order to verify the energy release rate estimates made from burn area analysis, a qualitative indicator can be used. In reviewing data it has been observed that the thermocouple measuring corridor ceiling gas temperature responds very quickly to burning rate changes. Figure 7 displays ceiling gas temperature response for experiment 346 in which the predominant energy contribution was from the burning cribs. The temperature levels in the burn room and doorway indicate flaming after 400 seconds. Outside this combustion zone the temperature drops significantly (Y = 10 $\mathrm{ft}, 20 \mathrm{ft}$, and $30 \mathrm{ft}$ ), and is a more direct indicator of energy rate released by combustion. Hence, the increase in gas temperature at $\mathrm{Y}=10$ ft can be used as a qualitative indicator of energy input rate up to flashover. These results are displayed in figures $8 \mathrm{a}, \mathrm{b}, \mathrm{c}$, and $\mathrm{d}$ for experiments 346, 347, 348, and 349, respectively. Figure 8a indicates a maximum $\Delta \mathrm{T}$ at $\mathrm{Y}=10 \mathrm{ft}$ of about $380{ }^{\circ} \mathrm{C}$ which can be associated with the maximum crib energy release rate. Before flashover and during periods when the floor covering was burning $\Delta \mathrm{T}$ at $\mathrm{Y}=10 \mathrm{ft}$ is about $420{ }^{\circ} \mathrm{C}$ for experiment $347,550{ }^{\circ} \mathrm{C}$ for experiment 348, and $450{ }^{\circ} \mathrm{C}$ for experiment 349 . Except for experiment 348, these values are generally in qualitative agreement with floor covering energy release rate estimates.

\subsection{Heating Characteristics of the Floor Coverings}

The rate of heating of the floor covering materials before ignition and flashover is dependent on the radiant flux originated from the flames emerging from the doorway and the heated walls and ceiling. For the 
region near the doorway the heating rate is high and ignition occurs quickly. This is seen in figures $9 a, b, c$, and $d$ where floor surface temperature is plotted for each experiment. The time at the initial temperature rise is reflective of the variations in ignition characteristics of the wood cribs. Locations down from the doorway ( $\mathrm{Y}=6 \mathrm{ft}$ or $8 \mathrm{ft}$ ) display a heating characteristic indicative of most of the floor covering in the corridor. These curves are shown in figures $10 \mathrm{a}, \mathrm{b}, \mathrm{c}$, and $\mathrm{d}$. To serve as a guide in assessing the phase transitions which may occur for the floor coverings some transition temperatures are listed in table 3 for the materials in these experiments. It appears that the distinct temperature plateaus in figures $10 \mathrm{~b}$ and $10 \mathrm{c}$ can be interpreted as melting transitions for polypropylene and nylon, respectively. In addition it will be seen that these periods of no temperature rise can be associated with the periods of almost constant heat flux. Hence, these plateaus could be interpreted as periods of temporary equilibrium as well.

Table 3. Transition Temperatures

\begin{tabular}{|c|c|c|c|}
\hline Material & Polymer & $\begin{array}{l}\text { Melt Temperature } \\
\left({ }^{\circ} \mathrm{C}\right)\end{array}$ & $\begin{array}{c}\text { Decomposition Temp. } \\
\left({ }^{\circ} \mathrm{C}\right)\end{array}$ \\
\hline Viny 1 Sheet & PVC & --- & $200-300^{a}$ \\
\hline Olefin Carpet & Polypropylene & $165^{b}$ & $328-410^{\mathrm{a}}$ \\
\hline Nylon Carpet & Nylon & $216-260^{b}$ & $316^{b}$ \\
\hline $\begin{array}{l}\text { Red Oak } \\
\text { Flooring }\end{array}$ & Wood & --- & $200-320^{C}$ \\
\hline
\end{tabular}

a Source: Reference [6]

Source: Reference [8]

Cource: Reference [9]

The temperature distribution along the floor covering surface of the corridor is depicted in figures 11a, b, c, and d. Figure 1la indicates the highest temperatures attained by the vinyl sheet flooring. In experiment 347 only a small change in heating is seen to occur preceding flashover, i.e. between 500 to 800 seconds. At most, about the first ten feet of the polypropylene carpet could have been melting. A similar heating behavior is seen for the nylon carpet in experiment 348. The red oak floor in experiment 349 appears to have been on the verge of pyrolyzing over the first six feet of corridor just before flashover. Although a significant portion of the floor covering materials in each of these experiments has received a severe exposure to heat, it does not appear that this alone is the cause of flashover. The carpet temperatures were almost steady for at least 5 minutes before flashover in experiment 347 and yet the flame is spreading slowly during this period. Then, suddenly flashover occurred near the doorway corridor region without any advance warning based on the floor temperature levels. Based on the thermocouple response there appears to be no sudden release of pyrolysis products from 
the nonflaming floor covering preceding flashover. Thus, this flashover phenomenon does not appear to be caused by rapid rise of a large section of floor covering to its "ignition temperature" or a release of pyrolysis products from large sections of floor covering which is ignited as a cloud of combustible gas. In fact, even after flashover in experiment 347, the nonburning region of floor covering has not reached its decomposition temperature. However, it is expected that this preheating before flashover does enhance flame spread over the flooring material and a small increase in heat transfer to the floor could trigger a rapid flame spread.

\subsection{Radiant Heat Flux to the Floor Covering}

Although four radiometers facing upwards were positioned along the corridor floor to measure incident radiant flux continuously, they had some deficiencies which precluded an accurate quantitative interpretation of these data. Basically, the use of a sapphire window in the radiometers excluded long wavelength radiation (above about $5 \mu \mathrm{m}$ ) from being transmitted to the sensor element of the instrument. A theoretical estimate along with some experimental corroboration shown in figure 12 indicates the magnitude of the radiation transmitted by sapphire for a blackbody source. During the experiments the radiometers (and the floor coverings) not only see the heated surfaces which respond as grey bodies, but also hot combustion products which include particulate and gaseous emittors of radiant energy. The gaseous combustion products emit most radiant energy below $5 \mu \mathrm{m}$ which would be completely recorded by the radiometer. Smoke particles in the products emit continuously as a function of wavelength with a blackbody distribution. The smoke particles had a higher temperature than the ceiling or walls in these experiments, so it follows from figure 12 that the fraction of emitted energy recorded by the radiometers would be greater for smoke (and flames) than for the ceiling and walls. Hence, the radiometers would be more responsive to radiation from the hot products than from radiation from the heated ceiling and walls.

A calculation scheme was developed to estimate the incident radiative flux along the corridor floor based upon the heated walls and ceiling. The surfaces were assumed to be blackbodies. The ceiling, upper half of the side walls, and rear wall were included. The source temperature distribution was based on the ceiling temperature measurements and was assumed to be a function of position $Y$ (and time) only. The details of this calculation are described in appendix $C$. The results provide at least a qualitative measure of the distribution of incident heat flux to the floor covering materials before flashover. Also, they provide some insight in assessing the source of radiation when these results are compared with the radiometer measurements. In general, the radiometer measured flux was lower than the calculated flux. However, "when black smoke passed along the corridor (e.g. due to ignition of the flooring in the burn room), then the radiometer reading exceeded the calculated flux value. It was estimated that the flux contribution from high temperature soot particles could be significant (i.e. approximately 3 watts $/ \mathrm{cm}^{2}$ ). 
Some of the calculated heat flux results along with measured values are presented in figures $13 a, b$, and $c$. No results are available for experiment 347. Preceding flashover, the highest radiant heat flux to the floor occurred in experiment 348 followed by 349 and then 346 . This is consistent with the energy release rate implied by corridor gas temperature results for the flooring materials. Thus, an increase in smoke and energy release of the materials may have caused a corresponding increase in radiant heat flux to the floor. If radiant flux to the floor originated from the heatẻd walls and ceilings, the measured results should be below the calculated results from ceiling temperature data due to the error caused by the sapphire window. This is the case in figures 13a and 13c. However, in experiment 348 (fig. 13b) the measured incident radiant flux, before flashover, actually increased, then decreased. The increase exceeded the calculated value and was probably due to radiation from smoke. A more detailed analysis of radiation from combustion products in these experiments is considered by Bromberg and Quintiere [10].

\subsection{Ventilation Effects}

It has been suggested that ventilation effects are the source of the differences between the IITRI carpet experiments and the NBS experiments. The data from the pitot tubes at the burn room doorway and corridor exhaust window were examined to explore this effect. Initially, the data from the pitot tubes aligned to measure the air inflow through the corridor window and into the burn room were examined. The quality of these data were poor or the response on the pressure transducers was too small to yield an accurate velocity measurement. The data from the pitot tubes which monitored the exhaust products were then examined. While the corridor exit window exhaust flow tended, generally, to increase or remain stationary during the experiment, the exhaust products from the burn room tended to decrease in velocity before flashover. This implies a decrease in the airflow to the burn room to support crib combustion. The burn room exhaust flow data was then analyzed to determine the magnitude of the induced flow rate of air.

The velocities measured by the doorway exhaust pitot tubes are shown for experiments 346, 348, and 349 in figures $14 \mathrm{a}, \mathrm{b}$, and c, respectively. No data are available for experiment 347. In experiment 346 no flashover occurred and the velocity data tended to follow the crib burning rate response. However, in experiments 348 and 349 there was a steady drop in the exhaust velocities up to 2 minutes before flashover. In fact the pitot tubes gave a negative pressure drop reading after flashover. This suggests that reverse flow or large cross flow eddies occurred in the doorway. This reduction of exhaust velocities at the doorway has been recorded in previous experiments. In particular, in an earlier experiment (336), which did not have a sustained flame spread, a localized flashover occurred preceded by a reduction in exhaust velocity. Subsequently, the crib burning rate dropped by $1 / 2$, but no rapid flame spread developed. 
By using these velocity data an average exhaust mass flow rate was estimated based on air properties as the exhaust fluid. Knowing the weight loss rate of the cribs the inflow of air through the doorway was found by

$$
\dot{\mathrm{M}}_{\text {air }}=\overline{(\rho \mathrm{OA})} \text { out }-4 \dot{\mathrm{M}}_{\substack{\text { single } \\ \text { crib }}}
$$

This not only includes the airflow in through the doorway, but also the air inflow through the two vents in the burn room. In experiment 346 this inlet vent flow was monitored and a mass inflow rate of approximately 20 1b/min was estimated during fully developed room fire conditions. Excluded in the above equation is the mass production rate of flooring material burning in the burn room. If a fuel to air mass ratio $\left(\gamma_{f a}\right)$ of 0.25 is used for the complete stoichiometric combustion of wood (fuel-air ratio can vary from 0.22 to 0.27 for wood) [11], then the potential burning rate can be determined. However, inefficient combustion is likely and not all of the air may be used for combustion in the burn room. Thus, $75 \%$ of the air (by mass) was assumed to be consumed, which corresponds to a volume $0_{2}$ concentration of about $5 \%$ - typical of measured $0_{2}$ concentration in the exhaust products before flashover. The results of these calculations are shown in figures $15 \mathrm{a}, \mathrm{b}$, and $\mathrm{c}$. The "potential fuel consumption" indicates the rate at which wood can be burned in the burn room based on available airflow. Based on a point velocity measurement at the vent, it was estimated that about half of the required airflow to support crib combustion enters through the vents. It is significant that more than sufficient airflow occurs in experiment 346 where no flashover occurred; yet, in experiments 348 and 349 airflow became insufficient before or at flashover. This implies that fuel gases can be released from the burn room before they are burned. Whether this is the cause of the flashover phenomenon that occurs in these experiments is not completely known; however, these calculations present strong evidence that ventilation effects are significant before flashover.

The cause of the flow decrease to the burn room can only be speculated on. Flow into the corridor system is basically determined by the temperature difference between the corridor-room system and the outside air. Flow between the room and corridor will also be determined by temperature differences between the two compartments. It appears that the extent of flame spread on the corridor floor also can have a significant effect on the airflow. It may be that once a critical floor area is burning in the corridor ahead of the doorway, then the incoming air flow is heated sufficiently to cause it to rise and flow back out of the corridor rather than into the burn room. Although this depletion of air would affect the burning rate of the wood cribs, this effect would lag the reduction in air flow. This follows because once the cribs build up to a fully developed burning stage the heat transfer between the sticks maintain the gasification of the wood. Reducing the airflow would shut off the release of energy during oxidation within the crib vertical shafts; however, glowing surfaces 
of the sticks would maintain high heat transfer to continue the gasification process for some time. Thus, the cribs would continue to supply fuel gases for at least a short time following loss of sufficient airflow. This sudden release of combustible gas to the rear of the corridor with heated air now mixing with it would result in combustion throughout the space. This is a plausible explanation of the flashover phenomenon that does occur. This would result in increased heat transfer to the corridor which can lead to the rapid flame spread phenomenon that most often follows flashover.

\section{SUMMARY AND CONCLUSIONS}

Four corridor fire experiments in the NBS facility have been reviewed. Each experiment investigated flame spread on a different floor covering material. Although each of these materials may be associated with a class of floor covering materials it would be improper to extend the results of these experiments to other materials of similar type. Indeed, the results of the NBS corridor experiments differ markedly from those of IITRI in terms of propensity to flashover. Yet, carpet materials were tested in both corridor facilities. Moreover, the differences between experimental results in these facilities suggest that the system variables are factors controlling flashover as well as the properties of the particular floor covering material tested. Thus, the initial constraints imposed by the experimental design can represent a subtle ingredient which can contribute significantly to the development of flashover.

On the other hand, the four experiments reviewed in this report should be representative of the preceding similar experiments conducted in this series (table 1). A summary of results for these four tests is given in table 4. Relative differences caused by the combustion behavior of the four materials can be seen. It was pointed out that the initial flame spread on to the corridor floor was promoted by the radiant heat received by the floor. Radiant heat flux results near the room doorway are shown in the table and compared to "critical" incident heat flux values necessary to sustain flame spread. (These "critical values" were determined in the apparatus described by Hartzel [12].) In experiments 348, 349, (and probably 347), the developed heat flux was much greater than the corresponding critical values; however, the critical flux is slightly higher than the developed heat flux in 346. This should explain why flame spread was not sustained in experiment 346. However, it does not necessarily explain why flashover developed in the other experiments. The peculiar flow behavior in the doorway which preceded flashover is another factor which must be considered in seeking a cause for flashover. Another contributing factor in each test, which depended on material, was the energy

release rate due to the floor fire. Since $24 \mathrm{ft}^{2}$ of floor covering was in the room, it was a significant source of energy release compared to that released in the corridor prior to flashover. It is clear from these four experiments that smoke and energy produced from the combustion of the floor material promoted higher radiation levels in the corridor, and hence, served to accelerate the development of the fire. 


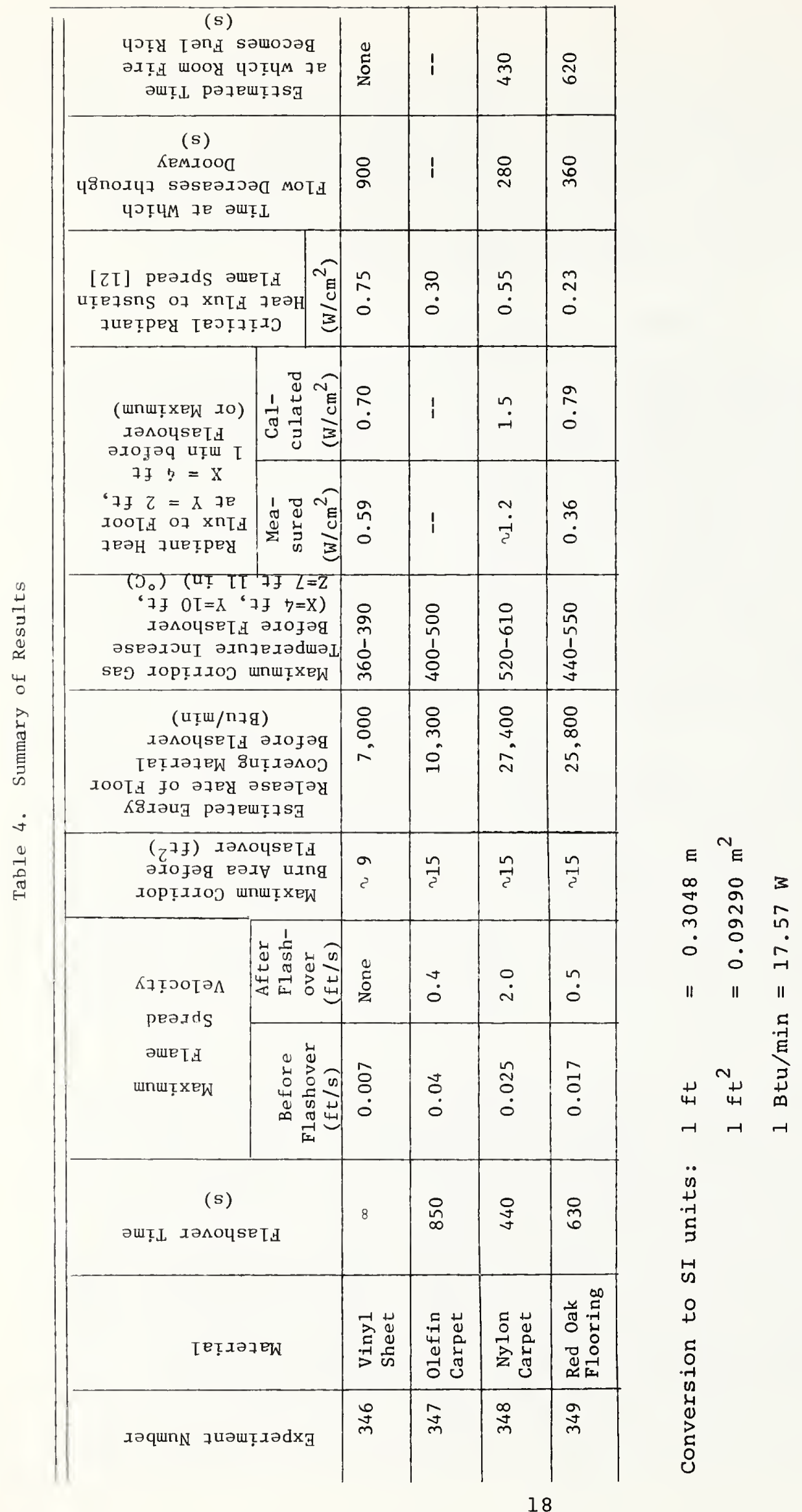


These experiments demonstrate the fact that flashover depends on the interaction of the burning material and its surroundings. A fire test method measures a fire "property" or characteristic of the material while burning in a particular environment. Correlation of flashover with fire test method results can be questionable unless both the test method and fire experiment are well understood. Even with this understanding, correlation of flashover with a relevent fire test method may prove to be insufficient since additional parameters related to the material and its environment may be important. As an analogy, one cannot correlate beam failure with the modulas of elasticity of the material. The load, moment of inertia, and yield stress must also be known.

\section{REFERENCES}

[1] Fung, F. C. W., Suchome1, M. R. and Oglesby, P. L., NBS Corridor Fire Tests: Energy and Radiation Models, Nat. Bur. Stand. (U.S.), Tech. Note 794 (Oct. 1973), GPO; SD Catalog No. C13.46:794; \$1.40.

[2] Quintiere, J. and Huggett, C., An Evaluation of Flame Spread Test Methods for Floor Covering Materials, Fire Safety Research, Proceedings of a Symposium held at the National Bureau of Standards on August 22, 1973, NBS Special Publication 411 (Nov. 1974).

[3] Christian, W. J. and Waterman, T. E., Characteristics of Full-Scale Fires in Various Occupancies, Fire Tech., Vo1. 7 (Aug. 1971).

[4] Scheffer, E. L. and Eickner, H. W., Corridor Wall Linings -- Effect on Fire Performance, Fire Tech., Vol. 1 (Nov. 1965).

[5] McGuire, J. H., The Spread of Fires in Corridors, Fire Tech., Vo1. 4 (May 1968).

[6] Hilado, C. J., ed., Flammability Handbook for Plastics, Technomic, p. 34 (1969).

[7] Birky, M. M., Combustion Product Analysis from Ful1-Scale Floor Covering Fires, Am. Chem. Soc., Polymer Preprints, Vol. 14 (Aug. 1973).

[8] Heimbold, N., ed., Textile World -- 1968 Man-Made Fiber Chart, McGraw-Hil1 (1968).

[9] Kanury, A. M. and Blackshear, P. L., Jr., Some Considerations Pertaining to the Problem of Wood-Burning, Comb. Sci. Tech., Vol. 1, pp. 339-335 (1970).

[10] Bromberg, K. and Quintiere, J., Radiative Heat Transfer from Products of Combustion in Building Corridor Fires, Nat. Bur. Stand. (U.S.), NBSIR 74-596 (Feb. 1975). 
[11] Block, J. A., A Theoretical and Experimental Study of Non-propagating Crib Fires, Ph.D. Dissertation, Harvard Univ., p. C-5 (1970).

[12] Hartzel, L. G., Development of a Radiant Panel Test for Flooring Materials, Nat. Bur. Stand. (U.S.), NBSIR 74-495 (May 1974). 
APPENDIX A. RESULTS OF CARPET FIRE EXPERIMENTS IN A CORRIDOR BY IITRI

In the course of attempting to determine the role of floor covering materials in fires along corridors, an effort was made to obtain information from other experimental studies of this question. Illinois Institute of Technology Research Institute (IITRI) performed carpet fire experiments in corridors for the Carpet and Rug Institute (CRI). The results of these experiments were not available in the literature. Consequently, Segall of CRI and Waterman of IITRI have supplied information from these experiments. Some of these results will be included in this appendix for reference. 


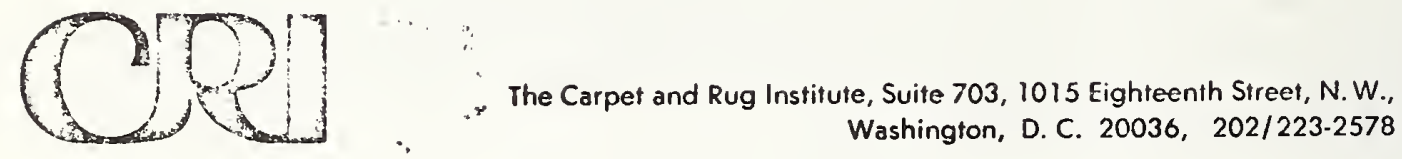

January 8, 1973

Dr. James Quintiere

Fire Technology Division

National Bureau of Standards

Washington, D. C. 20234

Dear Jim:

Enciosed is a copy of the section of the IITRI report dealing with their full-scale tests. Also enclosed is Table I giving carpet descriptions, and another table which includes pill test results, and some tunnel test results. Unfortunately, it appears that we did not have tunnel test figures on all of the carpet.

I assume that this is not much more information about the tests than you already have, but it is all that appears in our copy of the final report from IITRI.

Sincerely,

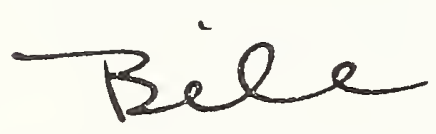

William M. Segall

Vice President

Government Affairs

WMS: $m b$

Enclosures 
Table I

CARPET SAMFLE DESCRIPTIONS (BENCH TEST)

\begin{tabular}{|c|c|c|c|c|}
\hline No. & Fiber & Type & $\begin{array}{l}\text { Approx. Pile } \\
\text { Thickness (in.) }\end{array}$ & $\begin{array}{l}\text { Approx. Total ut. } \\
0 z / s q \text { yd (pilo wt.) }\end{array}$ \\
\hline 1 & Acrylic & Tufted, Level Loop & .250 & $79(42)$ \\
\hline 2 & Acrylic & Tufted, Plush & .625 & $68(44)$ \\
\hline 3 & Acrylic & Tufted, Random Shear & .500 & $71(46)$ \\
\hline 6 & $\begin{array}{l}\text { Acrylic/ } \\
\text { Modacrylic }\end{array}$ & Tufted, Plush & .625 & $66(34)$ \\
\hline 10 & Nylon (S) & Tufted, Shag & .875 & $62(31)$ \\
\hline 11 & Nylon (S) & Tuiled, Plush & .220 & $68(20)$ \\
\hline 16 & Nylon (C.F.) & Tufted, Multi Level & .375 & $66(-3.5)$ \\
\hline 18 & Polyester (C.F.) & Tufted, Rardom Shiear & .500 & $81(30)$ \\
\hline 99 & bool & Tufted, Level Loop & .187 & $66(21)$ \\
\hline 20 & Wool & Tufted, Plush & .500 & $80(56)$ \\
\hline 21 & Wool & Tufted, Shag & 1.00 & $90(51)$ \\
\hline 22 & Wool & Woven, Level Loop & .250 & $81(47)$ \\
\hline 23 & $\begin{array}{l}\text { Acrylic/ } \\
\text { Modacrylic }\end{array}$ & Woven, Level Loop & .250 & 71 (42) \\
\hline 27 & Nylon (C.F.) & Tufted, level Loop & .250 & $68(20)$ \\
\hline 28 & Nylon (C.F.) & Tufted, Level Loop & & 104 \\
\hline 29 & Nylon (C.F.) & Tufted, Randon Shear & .562 & $58(20)$ \\
\hline 30 & Wool & Woven, Cut and Loop & .290 & $72(41)$ \\
\hline A & - Wool & Woven, Cut a:1d Loop & $3 / 8$ & $88(44)$ \\
\hline B & $\begin{array}{l}\text { Acrylic/ } \\
\text { Yodacrylic }\end{array}$ & Tufted, r lust: & $13 / 32$ & $75(36)$ \\
\hline c & Polyester & Tufred, Shag & $7 / 8$ & $72(32)$ \\
\hline
\end{tabular}


COMPARATIVE TEST RESLLTS

\begin{tabular}{|c|c|c|c|c|}
\hline $\begin{array}{c}\text { Sample } \\
\text { No. }\end{array}$ & F.S. & $\begin{array}{l}-84 \\
-S . D .\end{array}$ & Chamber & P11 \\
\hline 1 & 62 & 185 & - & Pass \\
\hline 2 & & - & - & Pass \\
\hline 3 & & - & - & Pass \\
\hline 6 & & - & - & Pass \\
\hline 10 & & - & - & Pass \\
\hline 11 & & - & - & Pass \\
\hline 16 & & - & - & Fail \\
\hline 18 & & - & - & Pass \\
\hline 19 & 183 & 34 & - & Pass \\
\hline 20 & & - & - & Pass \\
\hline 21 & & - & - & Pass \\
\hline 22 & 44 & 64 & - & Pass \\
\hline 23 & 45 & 90 & - & Pass \\
\hline 27 & 65 & 200 & - & Pass \\
\hline \multicolumn{5}{|l|}{28} \\
\hline 29 & 90 & 195 & - & Pass \\
\hline 30 & 49 & 39 & - & Pass \\
\hline A & 65 & 180 & - & Pass \\
\hline B & & - & - & Pass \\
\hline c & & - & - & Fa11 \\
\hline
\end{tabular}




\section{FULL-SCALE TESTS}

\section{A. EXPERIMENTAL FACILITY}

An existing instrumented room and cooridor complex was used to examine the fulloscale behavicr of selected carit pad combinations. This complex consists of a 10 by 15 by $8 \circ \mathrm{ft}$ high room connected to a 6 by $55 \mathrm{ft}$ by 8 -ft-high corridor (see Fig. 6). A $24 \mathrm{ft}$ section of the corridor flcor was carpered as shown in Fig. 6. The carpet and fad, if used, were stariled to asbestos silicate floor panels with standard installation tools. Walls of the facility are cf firebrick. Ceilings are transite covered.

The primary fire source was the room. All air to the rcom was by fire induced draft alung the corrider floor. Ccmbustion products exited via the upper corridor to an exhaust system at the corridor terminus. This terminus was within the main laj. oratory which provided a large reservolr of draft free air,

*optical density $=-\log$ (fraction of light crarsmiteded thruugh smoke),

\section{IIT RESEARCH INSTITUTE}




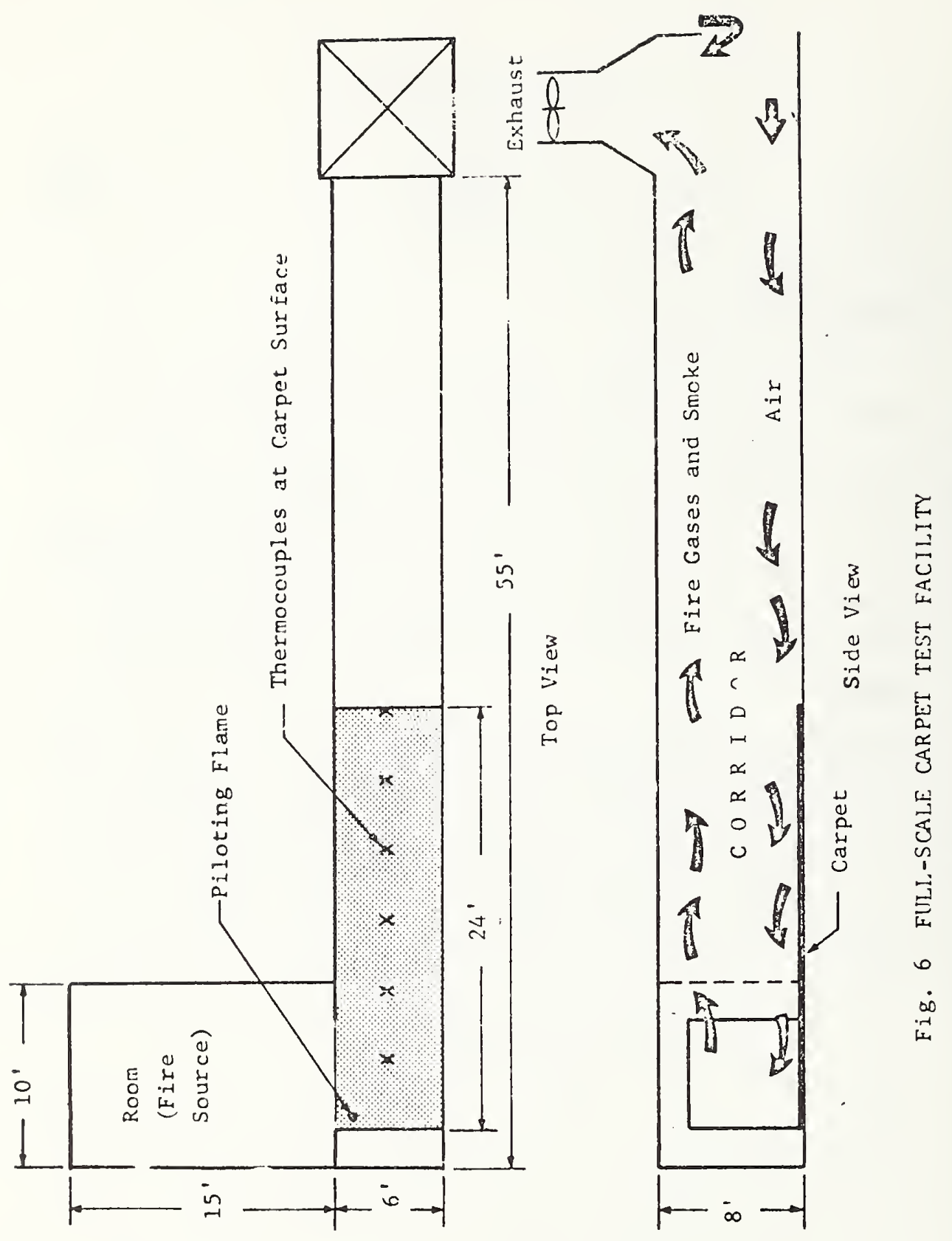


The exhaust system draws on this reservoir to provide corstant stack flow irrespective of the flow within the corrido: With constant flow, relative smoke production between samples can be evaluated from light attenuation in the exhaust stack as was done for the bench tests. In a similar masner, temperature measurements in the stack indicate relative heat costribut $10 n$.

Thermocouples were placed through the carpet every $4 \mathrm{ft}$ down the corridor centerline. Additional thermocouples were placed along the corridcr ceiling and in the rocm. The rocm. fire was generated with a stries of propane diıfusiun burners operated at $125,000 \mathrm{Btu} / \mathrm{min}$. This "standard" firt was developed on another program and is based upon the burning of a number of real contents fires within the rocm space. The fire develops a radiant flux intensity of 0.65 calories $/ \mathrm{cm}^{2}-\mathrm{sec}$ at $\mathrm{tne}$ flow across the corridor from the rocm.

\section{B. EXPER TMENTAL PROCEDURE}

At the start of each test, the room fire was initiated and immediately taken to full intensity. This might represent flashover of a room space and/or the sudden opening of a door between room and corridor. Simultanecusly, a small impinging pilot flame was directed at the face of the carpet near the doorway. This flame was used since the gas fire in the room does not emit sparks and small burning embers as would occir were the room filled with real contents items,

In addition to automatic data logging of the instrument package, visual observations were made of the fire frogress using small asbestos markers placed at measured points on the carpet for reference. Carpet fire behavior was recorded during and after the room fire burning period. A 20 min room fire duration was used which represents the peak burning period of the room when loaded with 5 lbs of real contents fuel per square foot of floor space. An example of this level of lcading is a crowded residential bedrocm.

IIT RESEARCH INSTITUTE 
As soon as practical after each test, the final burn fat. tern was carefully measured and sketched. Included with cach sketch were notes on the extent of charring or melting of the pile beyond the fire zone. Comments on the condition of back" ing and padding within various portions of the fire zore were also recorded.

\section{RESULTS}

Ten room corrjdor fire experiments were conducted. Three of these used a 40 oz hair pad, one placed a carper cuer a ripple rubber pad, and one sample had an integral pad of sponge rubber. In addition, a "reference" fire was conducted with a bare asbestos silicate floor. Sample descriptions and a summary of the results are shown in Table II.

Samples 10,18 and 19 were chosen since they received detailed study of the effects of pads in the bench tests, Sample 28, with integral pad, showed odd shrinkage and splitting of the facing to expose the sponge pad. This factor plus its high smoke production on the bench led to its inclusicn. Samples 2 and 21 showed high total burn distances cr the berich even without pads (sample 2 appeared marginally capable of self . sustained combustion) and thus were included in the series. Receipt of a second color of sample 2 by error led to its ins clusion in the series. This second sample was run with fad to produce what was predicted to be a "worst case" among the cest group. It should be noted that none of the samples supplied for full-scale tests were identical (see color) to those used for the bench tests conducted earlier. This factor assumed significance of unexpected magnitude as will be discussed later.

of first note in Table II is the fact that none of the carpet samples burned as much as $8 \mathrm{ft}$ beyond the room opening (the room opens along the first $6 \mathrm{ft}$ of sample). That is, r.cne showed behavior as hazardous as that exhibited by the group $c$ carpet described in section II. In fact, none burned quite as 


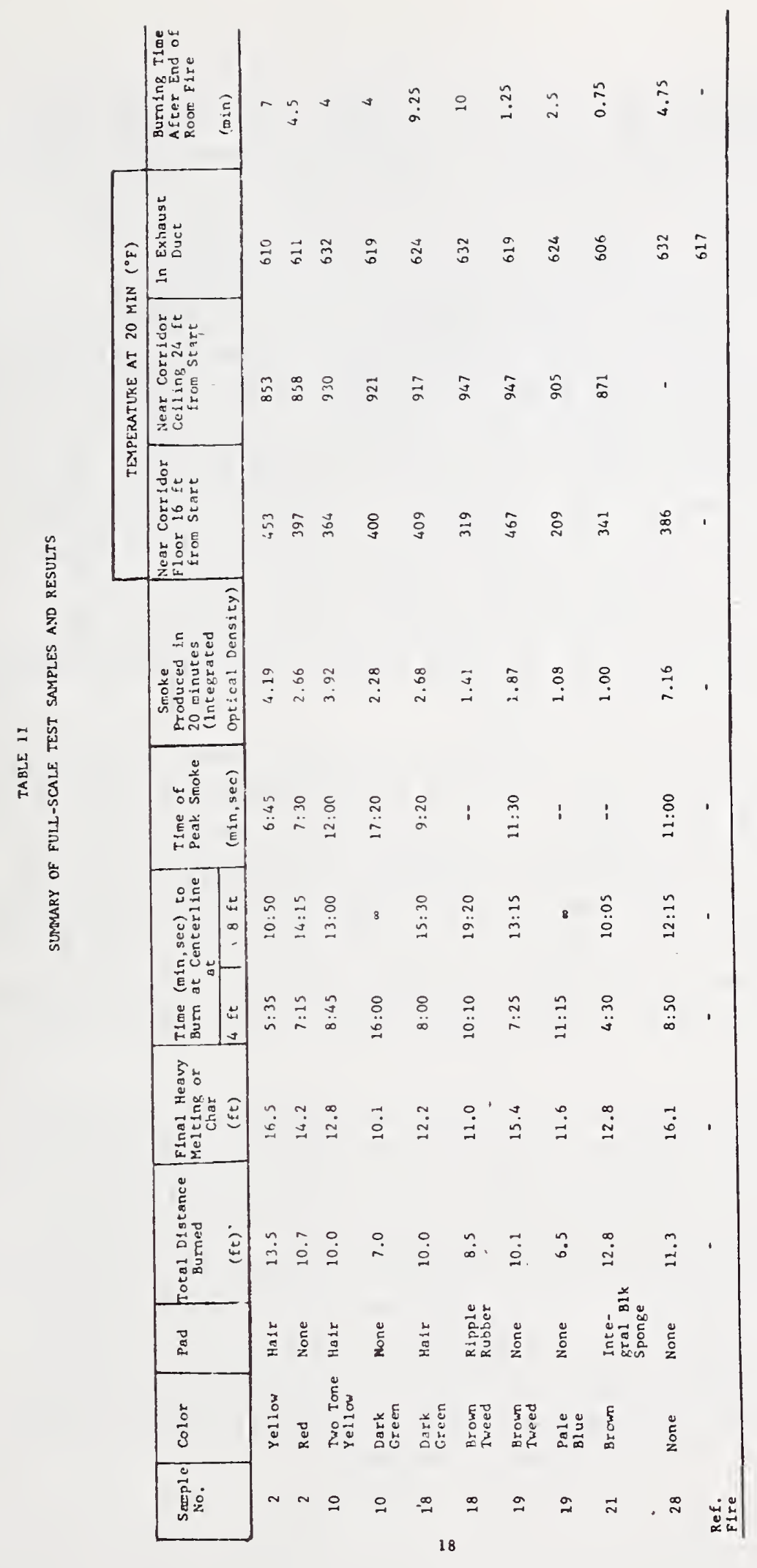


far as the group B carpet used previously. If assurance can be had that the samples examined here extend over the entire spectrum of behavior as 1 imited by the pill test, it would seem that, the pill test has eliminated those carpets that would have provoked rapid total corridor involvement.

Were an external draft through the room to extend into the corridor, one could expect the carpet to burn to greater distances. However, the general behavior should still be one in which the carpet essentially is burned by the room fire while contributing little to the tota? fire intensity. This can be seen in Table II by comparing corridor ceiling and ex. haust duct temperatures for experiments with carpet to those recorded for the reference fire. That is not to say that a draft in the corridor might not enhance self-heating of the carpet on a local basis ac the fire front by leaning the flames into and over the unburned pile.

Some indication of conditions near the carpet surface can be seen in the temperature level of a thermocouple just above the carpet pils (see Table II). It should be remembered, however, that this 28 gauge, unaspirated thermocouple will be radiantly heated above the local air temperature and connectively cooled differently than the carpet fibers and thus is not a complete descriptor of either. It does, however, show striking contrast to a corridor ceiling thermocouple which is also diso played in Table II.

Each full-scale fire followed the pattern of an initial delay followed by rapid spread to involve the area directly in front of the room opening. After this condition was reached, further spread was at a slow, decreasing rate. No sustained burning was encountered and the samples extinguished soon after the room fire was ended. An indication of the rate at which these stages evolved for each sample is shown by the time for flames to reach the carpet centerline at distances of 4 and $8 \mathrm{ft}$ from the start of the sample. The $4 \mathrm{ft}$ point is still in front

IIT RESEARCH INSTITUTE 
of the row opening and ihe Ilante frort pessou chis location while movirg across the arridor. The $\delta$ it lucution is $2 \mathrm{ft}$ beyond the room optining and, hy this point the flawe front was usually turned ald jisceeding don the corridor across its entire width.

The range of snoke output recorted in Table II cxtsnis upward to a value about cne-half that produced by a heavily furnished real bedrooti fire condicted in the same rocı as part of another program. It should be noted, however, that cnly abcut 7.5 yards of carpet were consumed in the corridor. Had the sane carpet been in the room, an additional 17 yards would have befn involved to produce smoke. 
Data supplied by Waterman from the IITRI carpet experiments were examined. The results from a single experiment (CRI 70-010) with carpet sample No. 28 will be considered. These results appear to be representative of most of these experiments. In this experiment, they report that carpet ignition occurred in about 2 min (after the room fire was initiated). Very heavy black smoke began evolving by $8 \mathrm{~min}$ which filled the corridor cross section from the ceiling to nearly the floor by 13 min. By this time, the carpet fire had advanced to $8 \mathrm{ft}$ in the corridor. At 20 min the room fire (gas burner) was turned off and a line fire continued to slowly advance on the carpet. At 15 min the line fire went out after having advanced $11.3 \mathrm{ft}$.

Gas temperature data near the corridor ceiling are shown in figure A-1 for this test. The results at the mid-corridor position are nearly identical with previous results from tests with the same room fire intensity, but without corridor combustible linings (Fire Tech., Aug. 1970). This implies a small relative energy release rate for carpet No. 28. A burn area curve is also shown in figure A-1. After 20 min, as was pointed out, the burning area is greatly reduced as the carpet fire becomes a line fire. 


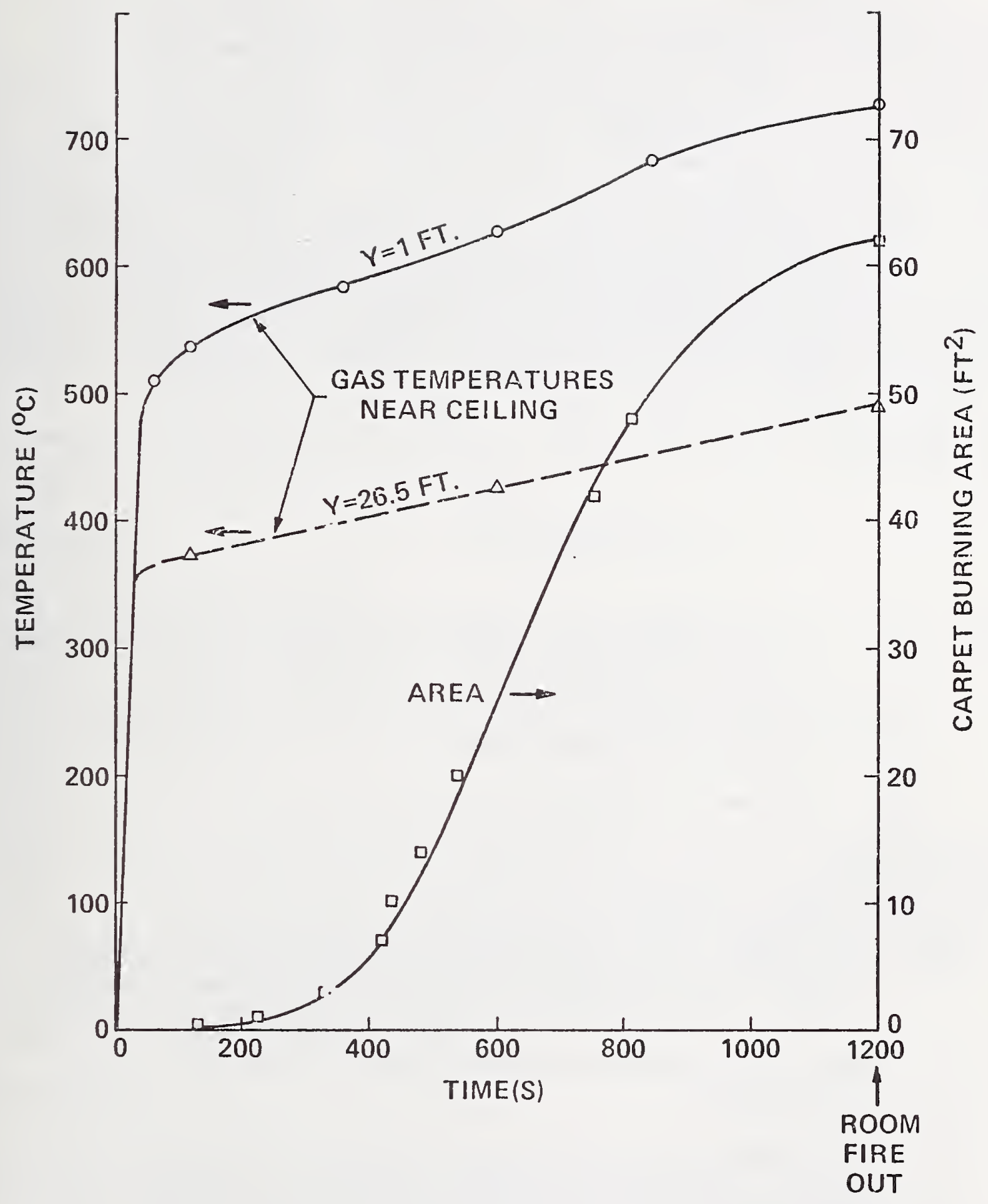

Figure $A-1$. Results from IITRI-CRI corridor carpet burn experiments

(CRI 70-010, carpet No. 28, propane gas room fire of 125,000 Btu/miri). 
APPENDIX B. ESTIMATE OF THE ENERGY RELEASE RATE PER UNIT AREA FOR THE FLOOR COVERING MATERIALS

It is assumed that the energy release rate per unit area is independent of time (invariant as the material burns in depth) and independent of floor position (invariant as surrounding conditions change). Before flashover the burning area extends from the burn room to a small portion of the corridor. Over most of this area the oxygen concentration and heat flux from the surroundings is assumed to be fairly uniform. Hence, the local burning rate should be fairly uniform. After flashover the floor heat flux will generally increase tending to increase burning rate, yet oxygen concentration is likely to drop tending to decrease burning rate. Since these two effects have a compensating influence on burning rate, the estimated value before flashover would still be reasonable. Moreover, if the average burning rate was based on burn room floor covering data where heat flux conditions are high before and after flashover, then a realistic estimate of the mean burning rate can be determined. This was essentially done.

In general the average energy release rate per unit floor area was determined by

$$
\dot{\mathrm{E}}_{\mathrm{F}}^{\prime \prime}=\frac{\Delta \mathrm{H}_{\mathrm{F}} \cdot \phi \cdot \mathrm{M}_{i}^{\prime \prime}}{\Delta \mathrm{t}_{\mathrm{b}}}
$$

where: $\Delta H_{F}=$ heat of combustion per unit initial mass of floor covering ${ }^{1}$

$\phi=$ fraction of combustibles in initial mass burned

$\stackrel{M}{\prime \prime}=$ initial mass per unit area

$\Delta t_{b}=$ duration of burning at a given location.

Experiment 346

The following data are given:

1. $\Delta \mathrm{H}_{\mathrm{F}}=12.13 \mathrm{MJ} / \mathrm{kg}$ based on the oxygen bomb calorimeter (A residue to $38 \%$ was left in the bomb indicating a high noncombustible content. This primarily included the inorganic felt backing.)

2. $\phi \sim 1=$ This is an assumption based on visible observations of the burned area.

3. $\mathrm{M}_{\dot{\mathrm{F}}}^{\prime \prime}=3.16 \mathrm{~kg} / \mathrm{m}^{2}$ 4. $\Delta t_{b}=700 \mathrm{~s}$ based on the longest burning of floor covering in the
burn room.

$$
\dot{\mathrm{E}}_{\mathrm{F}}^{\prime \prime} \quad=54.9 \mathrm{~kW} / \mathrm{m}^{2}\left(290 \mathrm{Btu} / \mathrm{min} \mathrm{ft}^{2}\right) \text {. }
$$

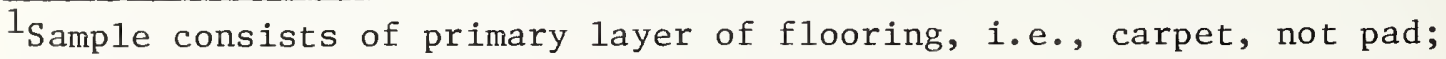
vinyl sheet, not adhesive; etc. 
The following data are given:

1. $\Delta \mathrm{H}_{\mathrm{F}}=20.75 \mathrm{MJ} / \mathrm{kg}$ based on the oxygen bomb calorimeter. (A noncombustible content of $28 \%$ was indicated.)

2. $\phi \sim 1=$ It is assumed that the burn room carpet was completely consumed.

3. $M_{\dot{L}}^{\prime \prime}=1.86 \mathrm{~kg} / \mathrm{m}^{2}$

4. $\Delta t_{b}=720 \mathrm{~s}-$ This is based on the earliest ignition of the burn room carpet and the time of extinguishment of the fire with water. Although thermocouple response indicates a decrease in floor temperature before water extinguishment, it was not sufficient to indicate a cessation of flaming. Hence, this burn time is approximate. Moreover, it is not uncommon for this carpet to burn for 10 minutes or more in laboratory tests of high heating exposure.

$$
\dot{\mathrm{E}}_{\mathrm{F}}^{\prime \prime}=54.1 \mathrm{~kW} / \mathrm{m}^{2}\left(286 \mathrm{Btu} / \mathrm{ft}^{2} \mathrm{~min}\right) \text {. }
$$

Experiment 348

The following data are given:

1. $\Delta \mathrm{H}_{\mathrm{F}}=19.2 \mathrm{MJ} / \mathrm{kg}$ based on the oxygen bomb calorimeter.

2. $\phi \sim 1=$ Based on weight loss measurements of carpet after fire at $\mathrm{Y}=1.5 \mathrm{ft}$

3. $\mathrm{M}_{\mathrm{L}}^{\prime \prime}=2.34 \mathrm{~kg} / \mathrm{m}^{2}$

4. $\Delta t_{b}=350 \mathrm{~s}-$ This burn time is the difference between time at extinguishment $(600 \mathrm{~s})$ and time of first carpet ignition in burn room $(250 \mathrm{~s})$. Thermocouple data indicate drop in temperature of flaming carpet in burn room at 500 s indicating burning time may be shorter. Also, burning time of carpet at $\mathrm{Y}=1.5$ $\mathrm{ft}$ is estimated at $170 \mathrm{~s}$.

$$
\dot{\mathrm{E}}_{\mathrm{F}}^{\prime \prime}=130 \mathrm{~kW} / \mathrm{m}^{2}\left(685 \mathrm{Btu} / \mathrm{ft}^{2} \mathrm{~min}\right) \text {. }
$$

Experiment 349

In this experiment wood samples of flooring from five locations were weighed after the fire. The initial weight of the samples before the experiment was unfortunately not determined. The density of wood varies too greatly to make estimates of weight loss based on the density of new flooring. Hence, the original density of the burned samples was estimated by removing the charred region from the wood and determining the density of the relatively unpyrolyzed remainder. The results of measurements for the five samples and two new samples of flooring are given in table B-1. 
Table B-1

Weight Loss and Heat of Combustion Results

for Red Oak Flooring Samples in Experiment 349

\begin{tabular}{|c|c|c|c|c|c|}
\hline $\begin{array}{c}\text { Sample } \\
\text { Location }\end{array}$ & $\begin{array}{c}\text { Depth of } \\
\text { Char } \\
\text { (cm) }\end{array}$ & $\begin{array}{l}\text { Final Mass } \\
\text { per Unit } \\
\text { Surface } 2 \text { Area } \\
\left(\mathrm{kg} / \mathrm{m}^{2}\right) \\
\end{array}$ & $\begin{array}{c}\text { Estimated Initial } \\
\text { Mass per Unit } \\
\text { Surface Area } \\
\left(\mathrm{kg} / \mathrm{m}^{2}\right) \\
\end{array}$ & $\begin{array}{l}\text { Burn } \\
\text { Time } \\
\text { (s) } \\
\end{array}$ & $\begin{array}{l}\text { Heat of } \\
\text { Combustion } \\
\text { for Residue } \\
(\mathrm{MJ} / \mathrm{kg})\end{array}$ \\
\hline Burn Room & 0.64 & 7.53 & 10.6 & 524 & 20.4 \\
\hline $\mathrm{Y}=2 \mathrm{ft}$ & 0.40 & 9.36 & 13.4 & 328 & 19.6 \\
\hline $\mathrm{Y}=5 \mathrm{ft}$ & 0.24 & 9.22 & 10.4 & 128 & -- \\
\hline $\mathrm{Y}=15 \mathrm{ft}$ & 0.08 & 12.0 & 13.4 & 88 & -- \\
\hline $\mathrm{Y}=25 \mathrm{ft}$ & 0.16 & 13.7 & 15.6 & 68 & -- \\
\hline New Wood & 0 & 12.7 & 12.7 & -- & 18.7 \\
\hline New Wood & 0 & 12.0 & 12.0 & -- & -- \\
\hline
\end{tabular}

Based on these measurements it was estimated that before flashover $(t>630 \mathrm{~s})$ the burning rate was approximately $7.04 \times 10^{-3} \mathrm{~kg} / \mathrm{m}^{2}-\mathrm{s}$ and approximately doubled after flashover. Using $\mathrm{H}_{\mathrm{F}}=18.7 \mathrm{MJ} / \mathrm{kg}$ based on new wood yields

$$
\dot{\mathrm{E}}_{\mathrm{F}}^{\prime \prime}=132 \mathrm{~kW} / \mathrm{m}^{2}\left(697 \mathrm{Btu} / \mathrm{ft}^{2} \mathrm{~min}\right)
$$

before flashover. If the combustible content of the char residue is considered, then this energy release rate is over estimated by approximately $25 \%$. However, this deviation is within the extent of variation of the initial estimate for wood density. 


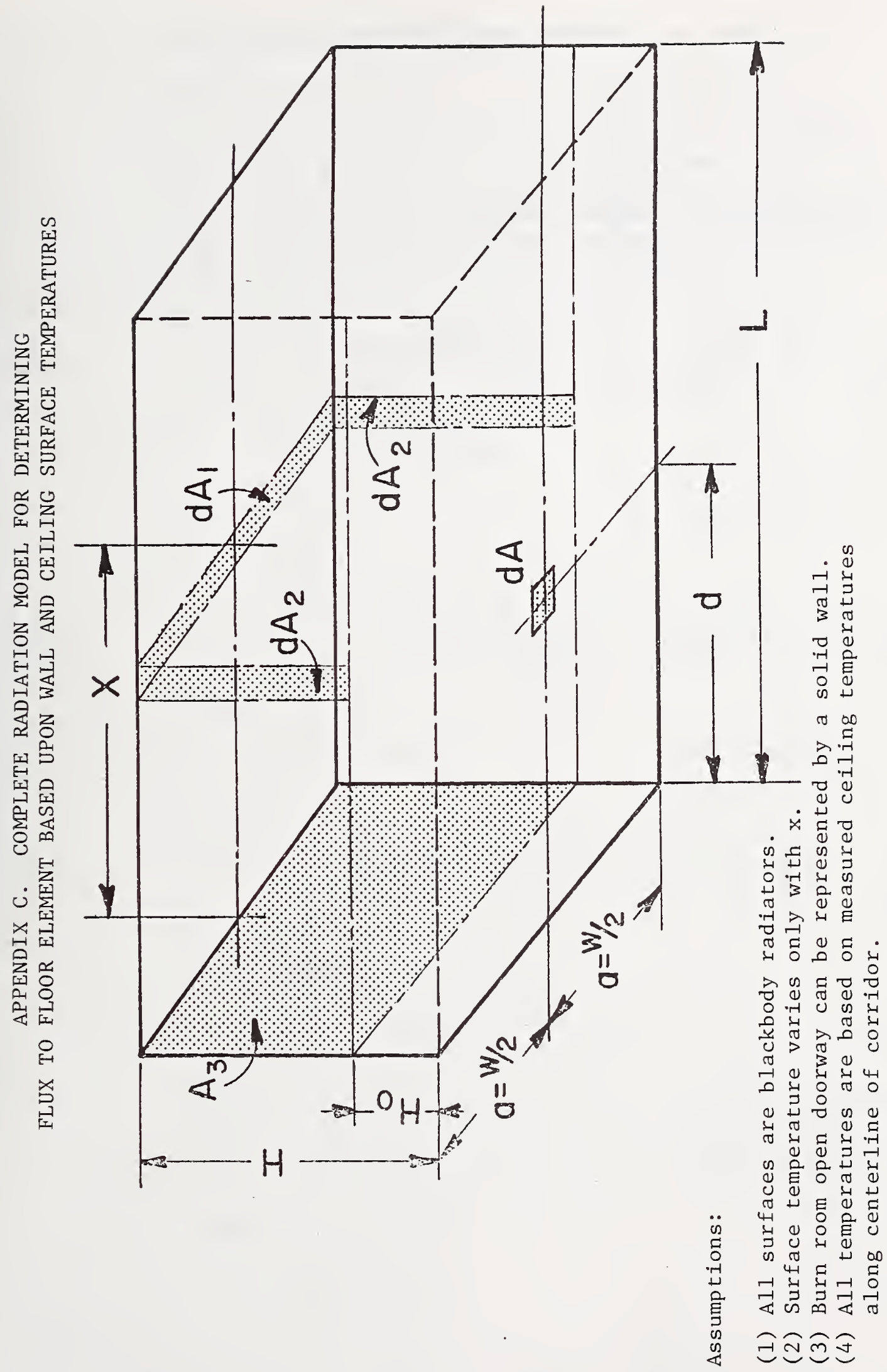


Radiant flux incident at a floor element $d A$ at any time is given as follows:

$$
\dot{q}^{\prime \prime}=\dot{q}_{\text {ceiling }}^{\prime \prime}+\dot{q}_{\substack{\text { side } \\ \text { walls }}}+\dot{q}_{\text {back }}^{\prime \prime}
$$

where

$$
\begin{aligned}
\dot{q}_{\text {ceiling }}^{\prime \prime} & =\frac{\sigma H^{2}}{\pi} \int_{0}^{L}\left[\frac{a}{R\left(R+a^{2}\right)}+\frac{\tan ^{-1}(a / \sqrt{R})}{R^{3 / 2}}\right] T^{4}(x) d x \\
a & =W / 2 \\
R & =(d-x)^{2}+H^{2} \\
\dot{q}_{\text {side }}^{\prime \prime} & =\frac{a \sigma}{\pi} \int_{0}^{L}\left[\frac{1}{\left(a^{2}+R_{0}\right)}-\frac{1}{\left(a^{2}+R\right)}\right] T^{4}(x) d x \\
\text { walls } & \\
R_{0} & =(x-d)^{2}+H_{0}^{2} \\
\dot{q}_{\text {back }}^{\prime \prime} & =\frac{\sigma d}{\pi}\left\{\frac{\tan ^{-1}\left(a / \sqrt{R_{0}}\right)}{\sqrt{R_{0}}}-\frac{\tan ^{-1}(a / \sqrt{R})}{\sqrt{R}}\right\} T^{4}(x) \mid \\
\text { wall } & \mid
\end{aligned}
$$

Constants:

$$
\begin{aligned}
& \mathrm{L}=30 \mathrm{ft}(9.1 \mathrm{~m}) \\
& \mathrm{W}=8 \mathrm{ft}(2.4 \mathrm{~m}) \\
& \mathrm{H}=8 \mathrm{ft}(2.4 \mathrm{~m}) \\
& \mathrm{H}_{\mathrm{O}}=4 \mathrm{ft}(1.2 \mathrm{~m})
\end{aligned}
$$


In view of present accepted practice in this technological area, U.S. customary units of measurement have been used throughout this report. It should be noted that the U.S. is a signatory to the General Conference on Weights and Measures which gave official status to the metric SI system of SI units in 1960. Readers interested in making use of the coherent system of SI units will find conversion factors in ASTM Standard Metric Practice Guide, ASTM Designation E 380-72 (available from American Society for Testing and Materials, 1916 Race Street, Philadelphia, Pennsylvania 19103). Conversion factors for units used in this paper are:

\section{$\underline{\text { Length }}$}

$$
\begin{aligned}
& 1 \text { in }=0.0254^{*} \text { metre } \\
& 1 \text { ft }=0.3048^{*} \text { metre }
\end{aligned}
$$

$\underline{\text { Area }}$

$$
\begin{aligned}
& 1 \text { in }^{2}=6.4516^{*} \times 10^{-4} \text { metre } \\
& 1 \mathrm{ft}^{2}=9.2903 \times 10^{-2} \text { metre }
\end{aligned}
$$

Mass

$$
11 \mathrm{~b}=0.4536 \mathrm{~kg}
$$

Energy

$$
1 \text { Btu }=1054 \mathrm{~J}
$$

\section{Temperature}

$$
\left.{ }^{\circ} \mathrm{C}=5 / 9 \text { (Temperature }{ }^{\circ} \mathrm{F}-32\right)
$$

\section{Power}

$$
1 \mathrm{Btu} / \mathrm{min}=17.57 \mathrm{~W}
$$

\section{Time}

$$
1 \min =60 \mathrm{~s}
$$

\footnotetext{
Exact Value
} 


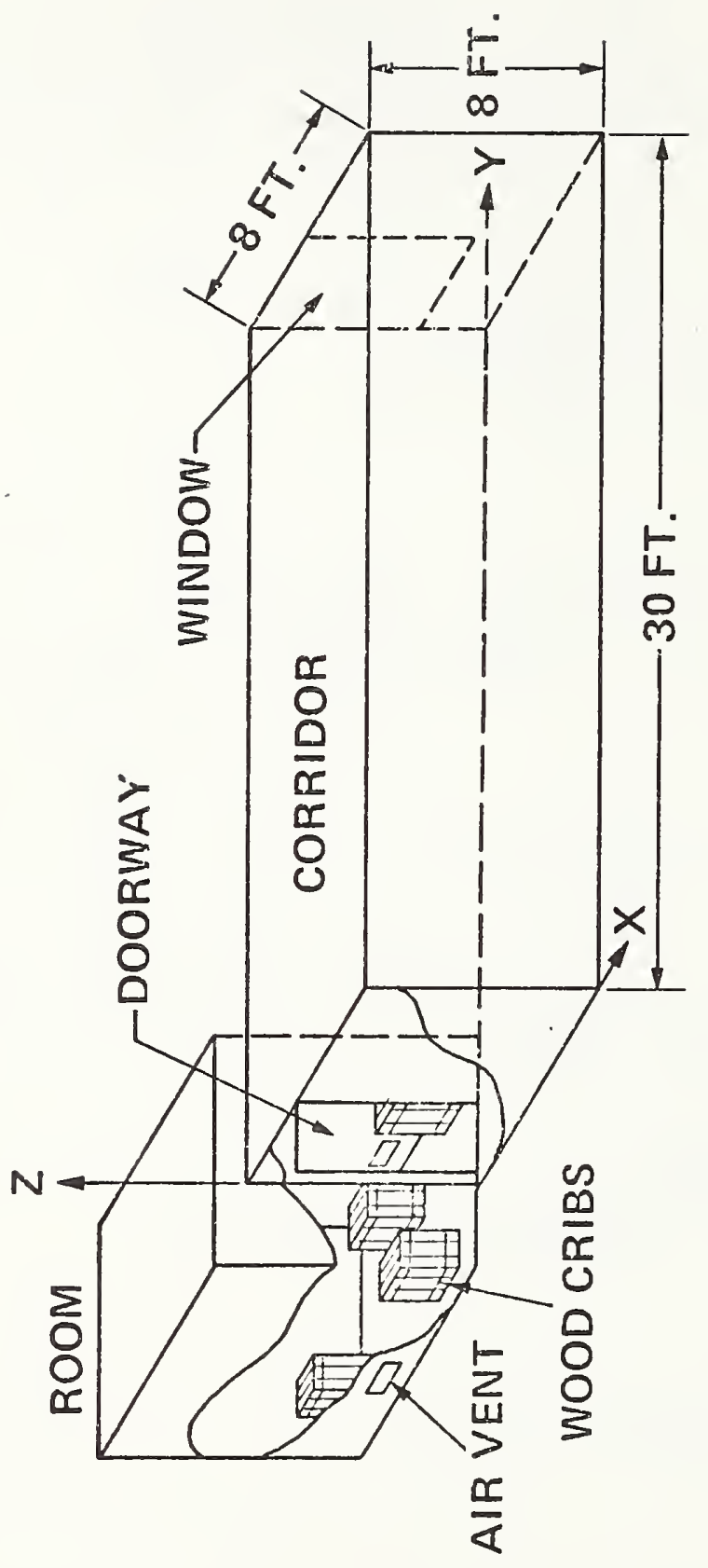

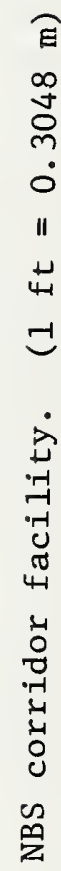

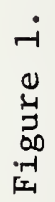




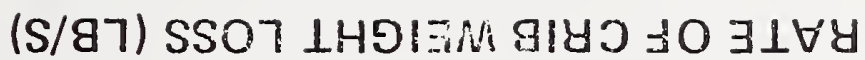

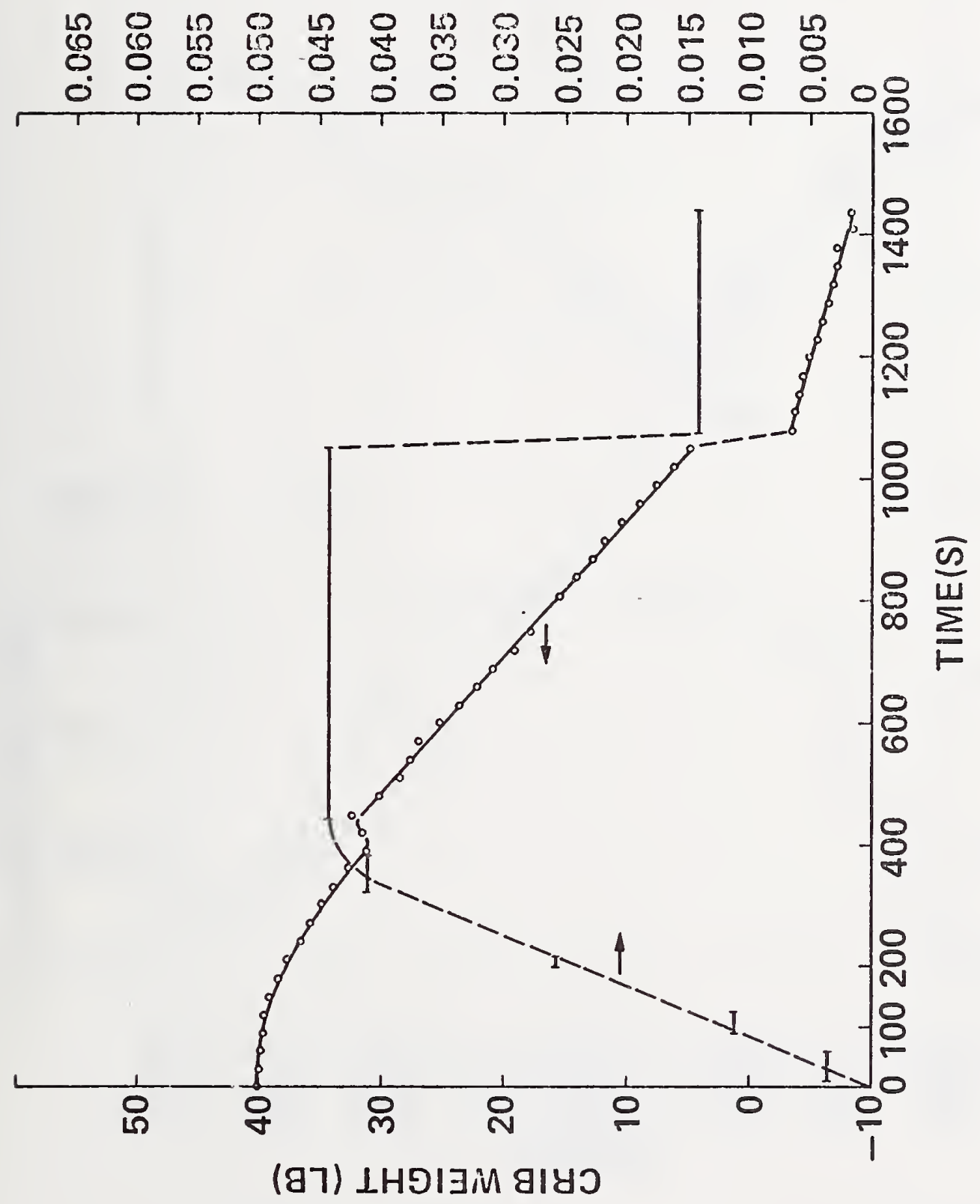

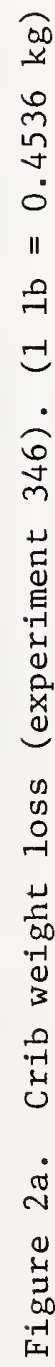




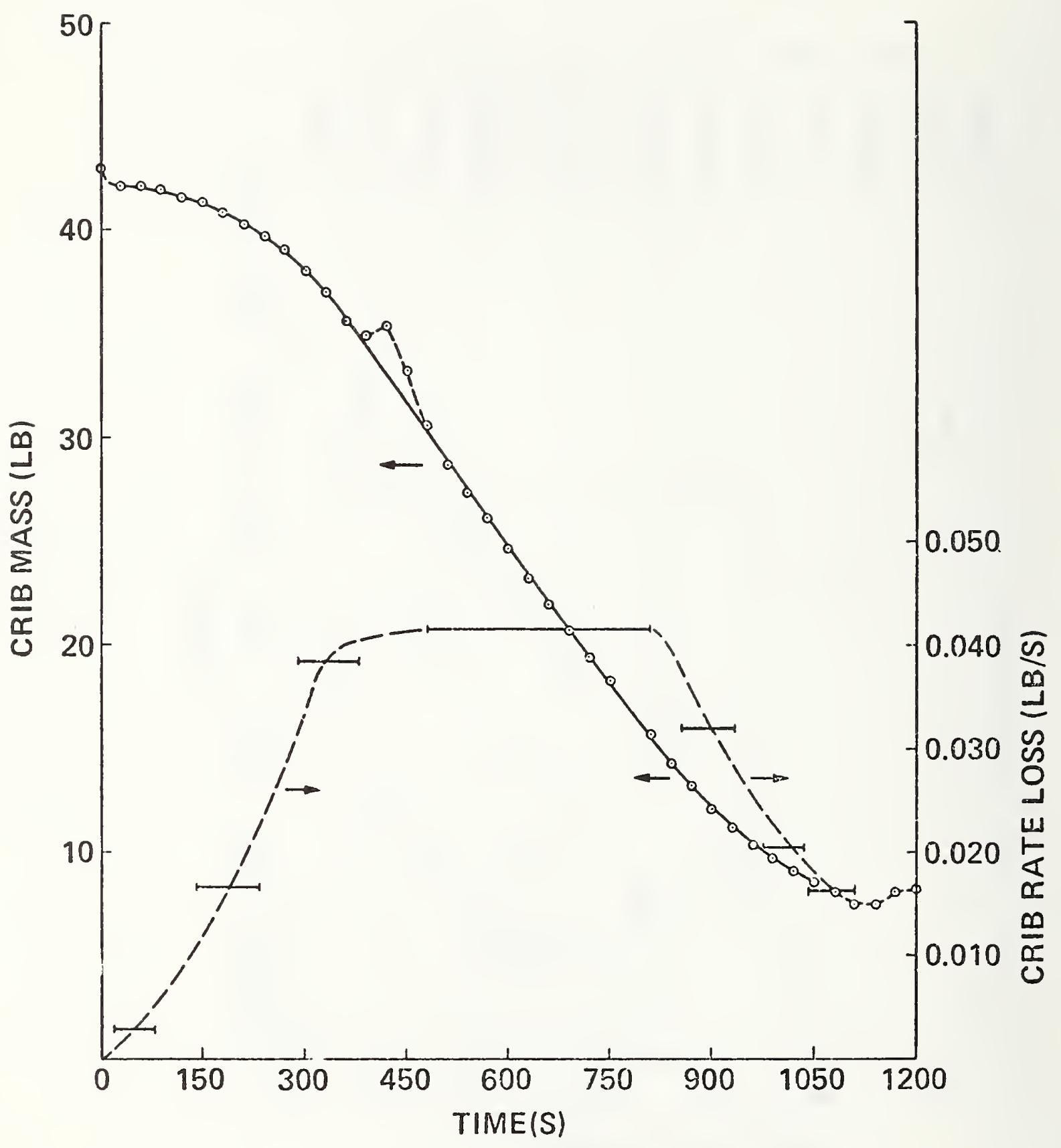

Figure 2b. Crib weight loss (experiment 347$).(1 \mathrm{lb}=0.4536 \mathrm{~kg})$ 


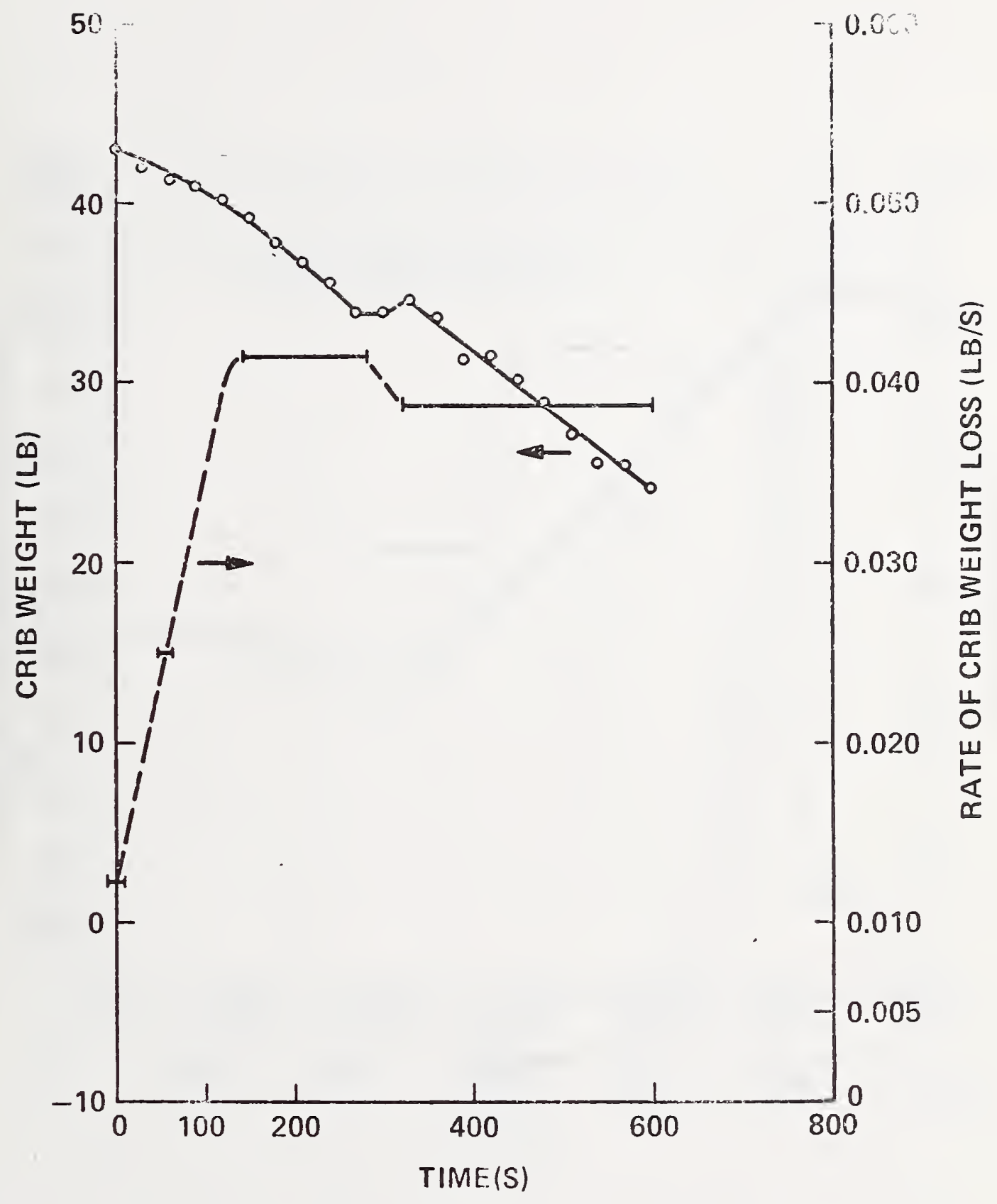

Figure 2c. Crib weight loss (experiment 348$).(1 \mathrm{lb}=0.4536 \mathrm{~kg})$ 43 


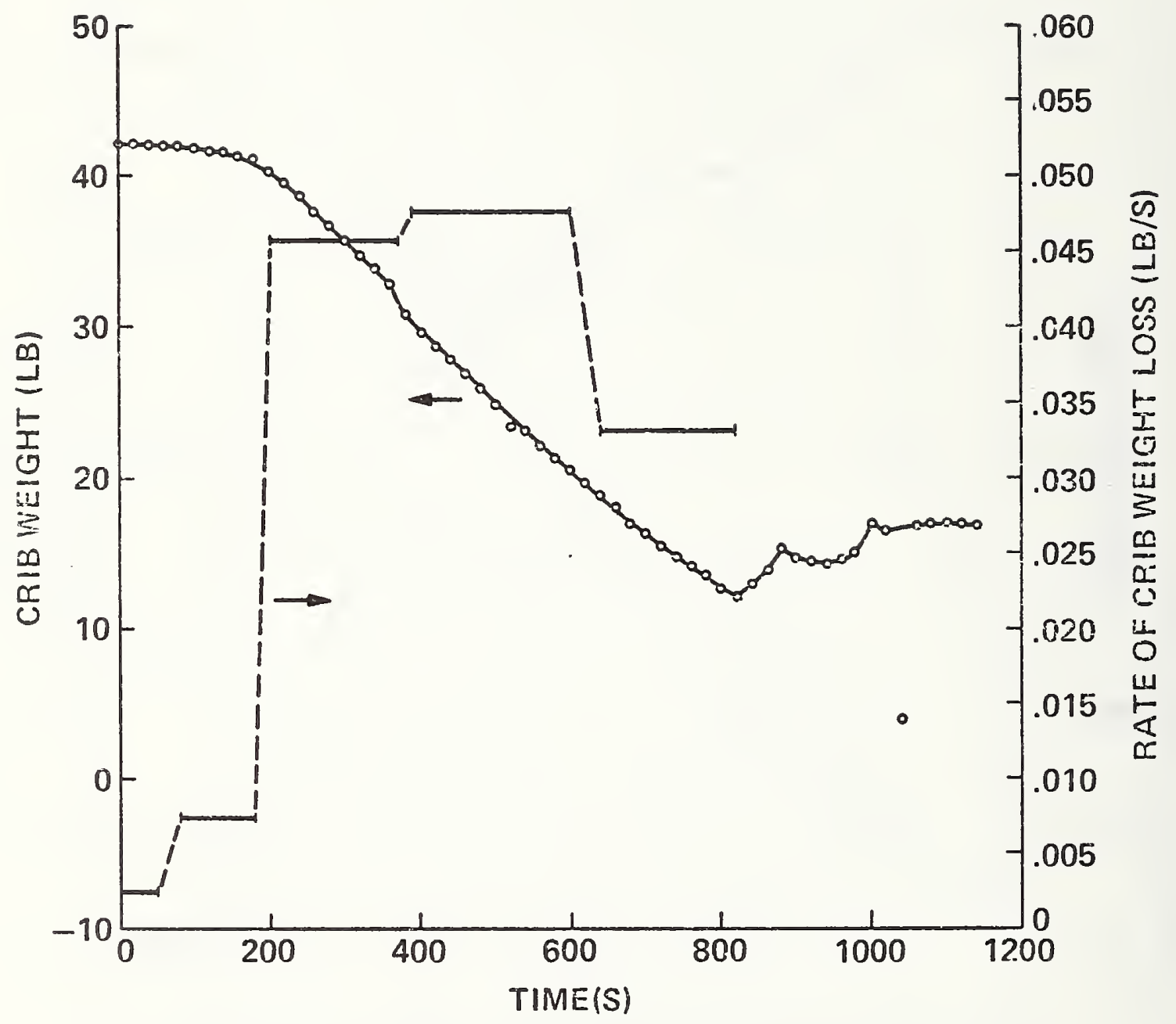

Figure 2d. Crib weight loss (experiment 349$)$. ( $1 \mathrm{lb}=0.4536 \mathrm{~kg}$ ) 


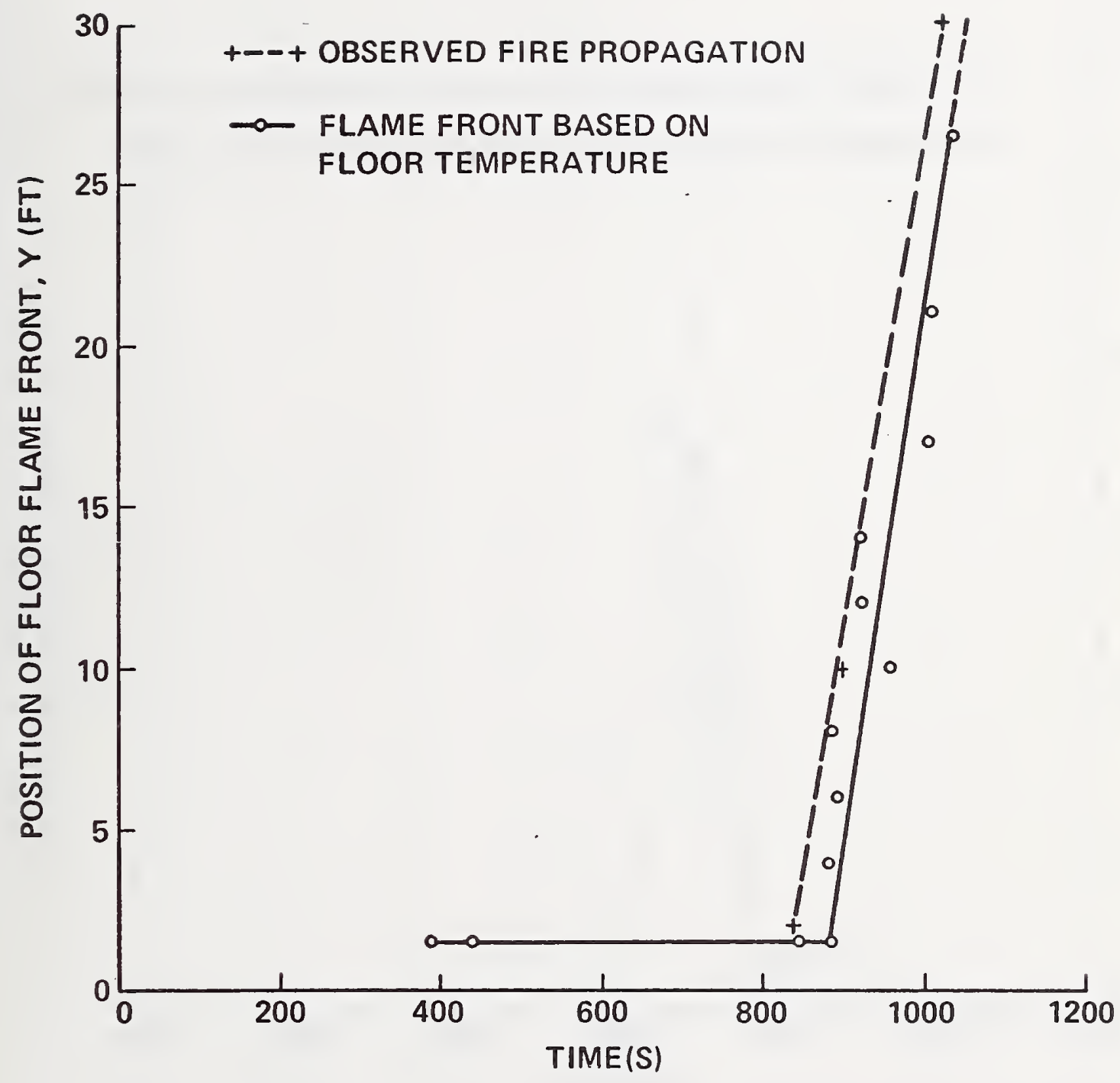

Figure 3a. Corridor flame spread (experiment 347$)$. $(1 \mathrm{ft}=$ $0.3048 \mathrm{~m}$ ) 


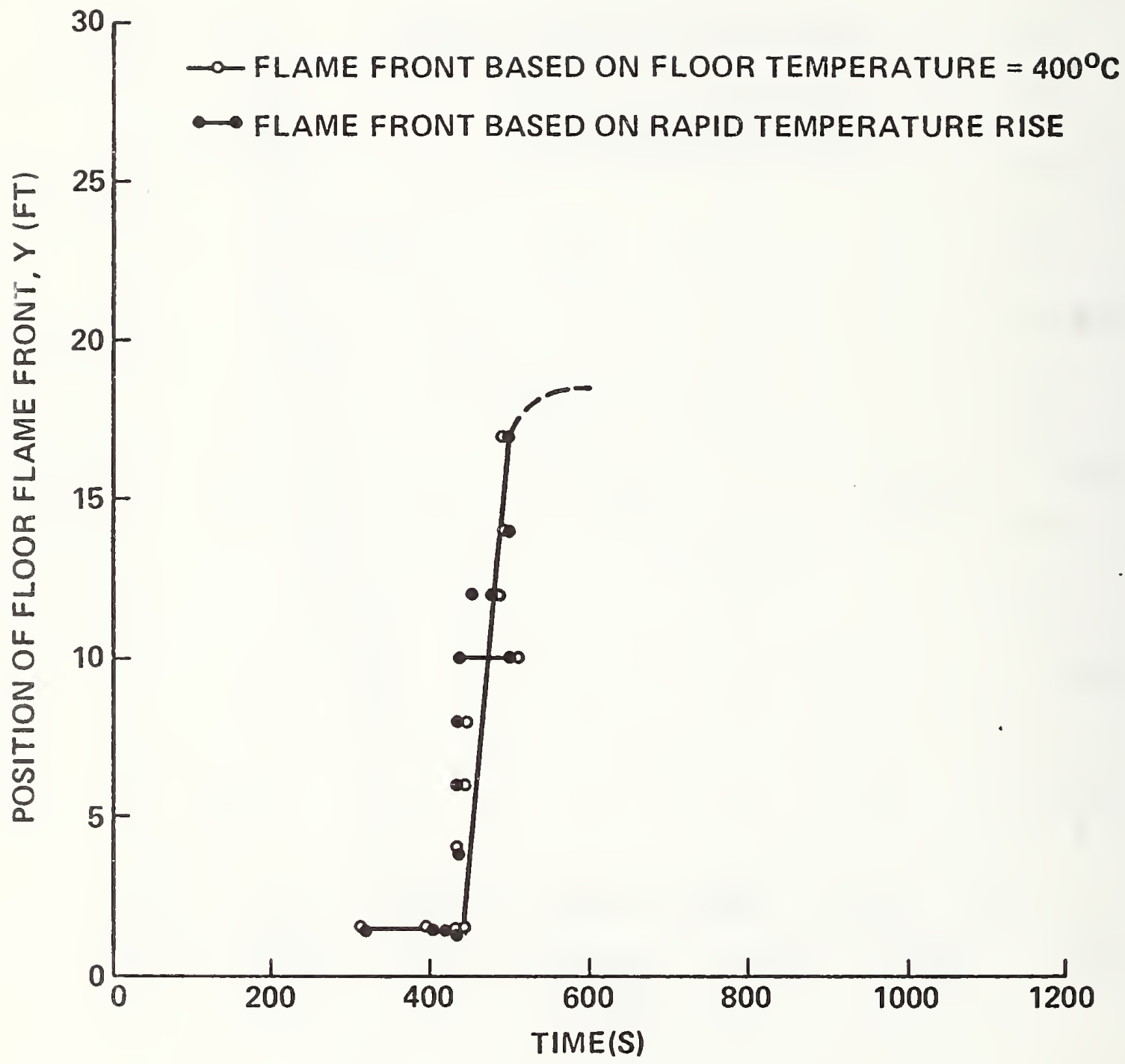

Figure 3b. Corridor flame spread (experiment 348). (1 ft $=0.3048 \mathrm{~m})$ 


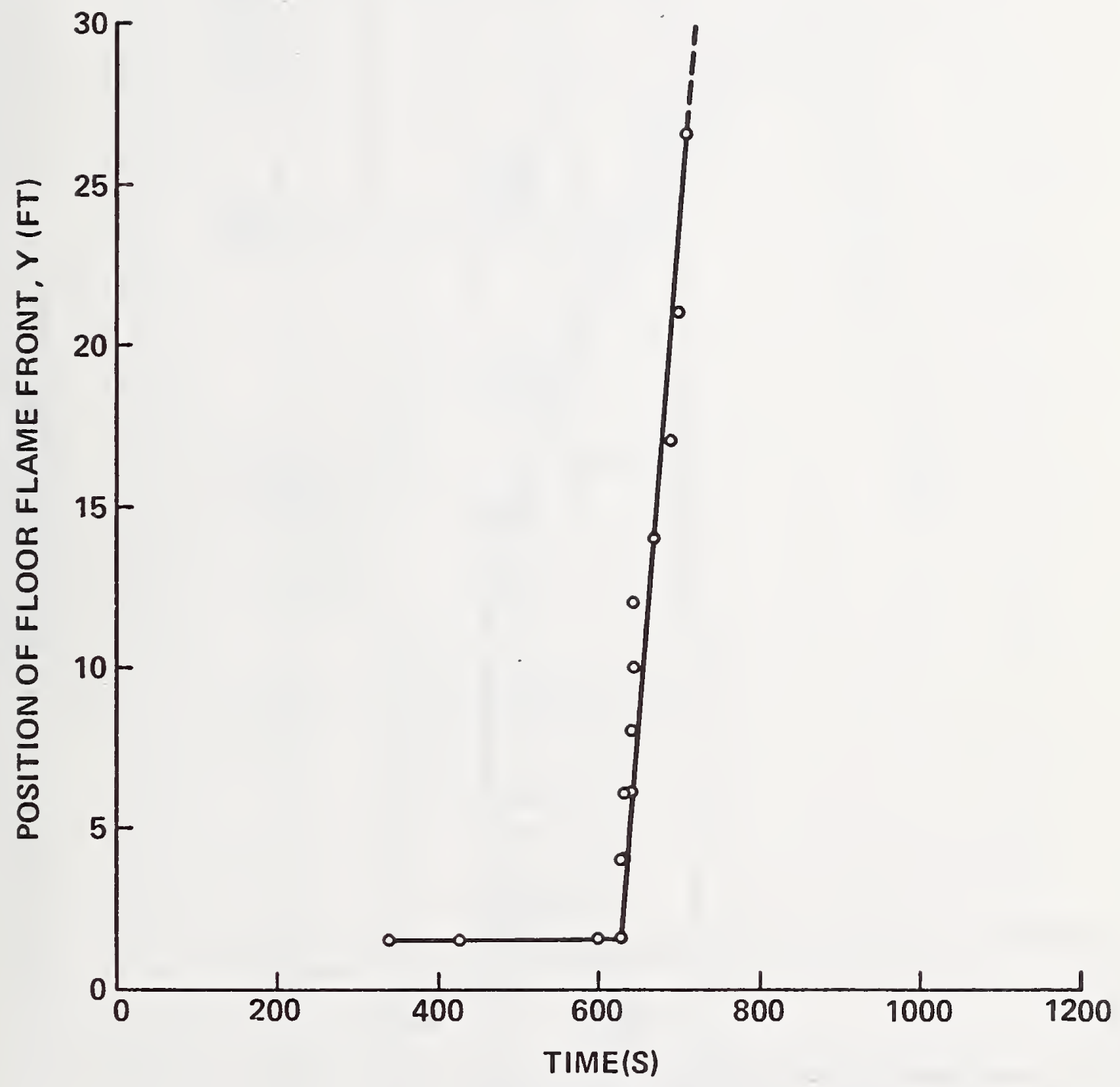

Figure 3c. Corridor flame spread (experiment 349). (1 ft $=0.3048 \mathrm{~m}$ ) 47 


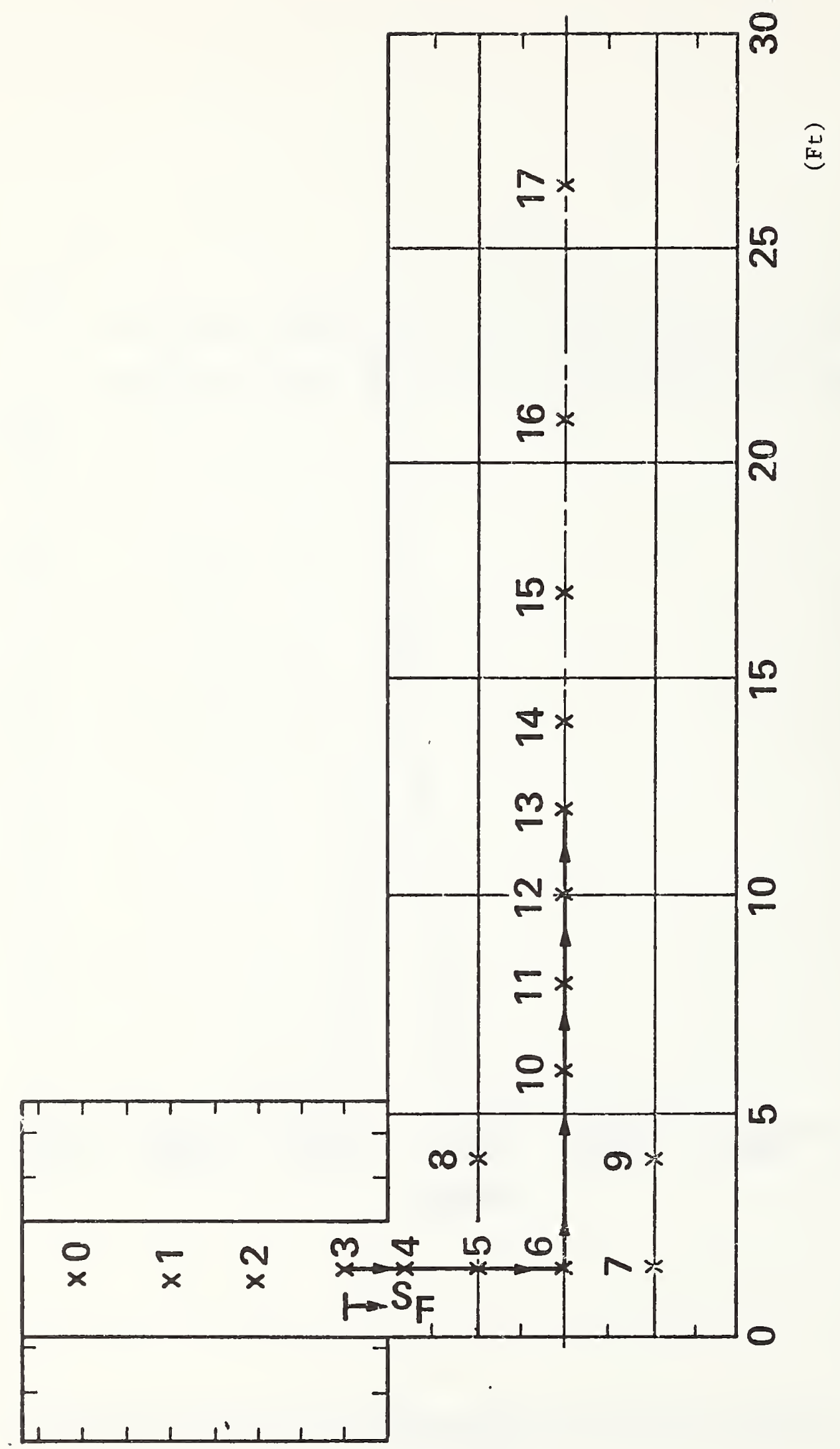

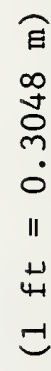

苟

莺

4

4

㔛

ฮี

ב

넘

$\stackrel{\mathbb{\sigma}}{\Im}$

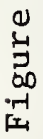




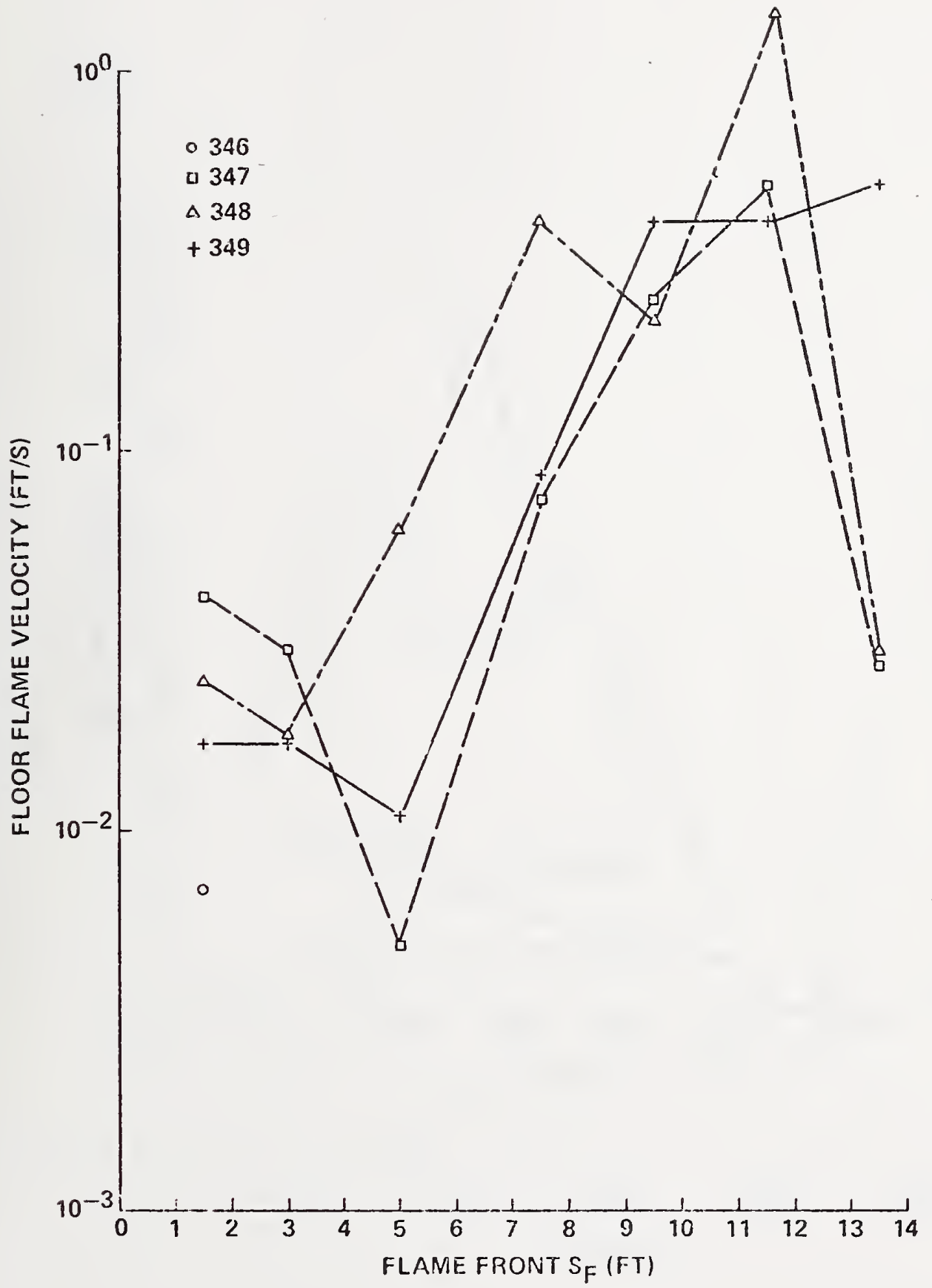

Figure 4b. Floor flame spread velocity. $(1 \mathrm{ft}=0.3048 \mathrm{~m})$ 


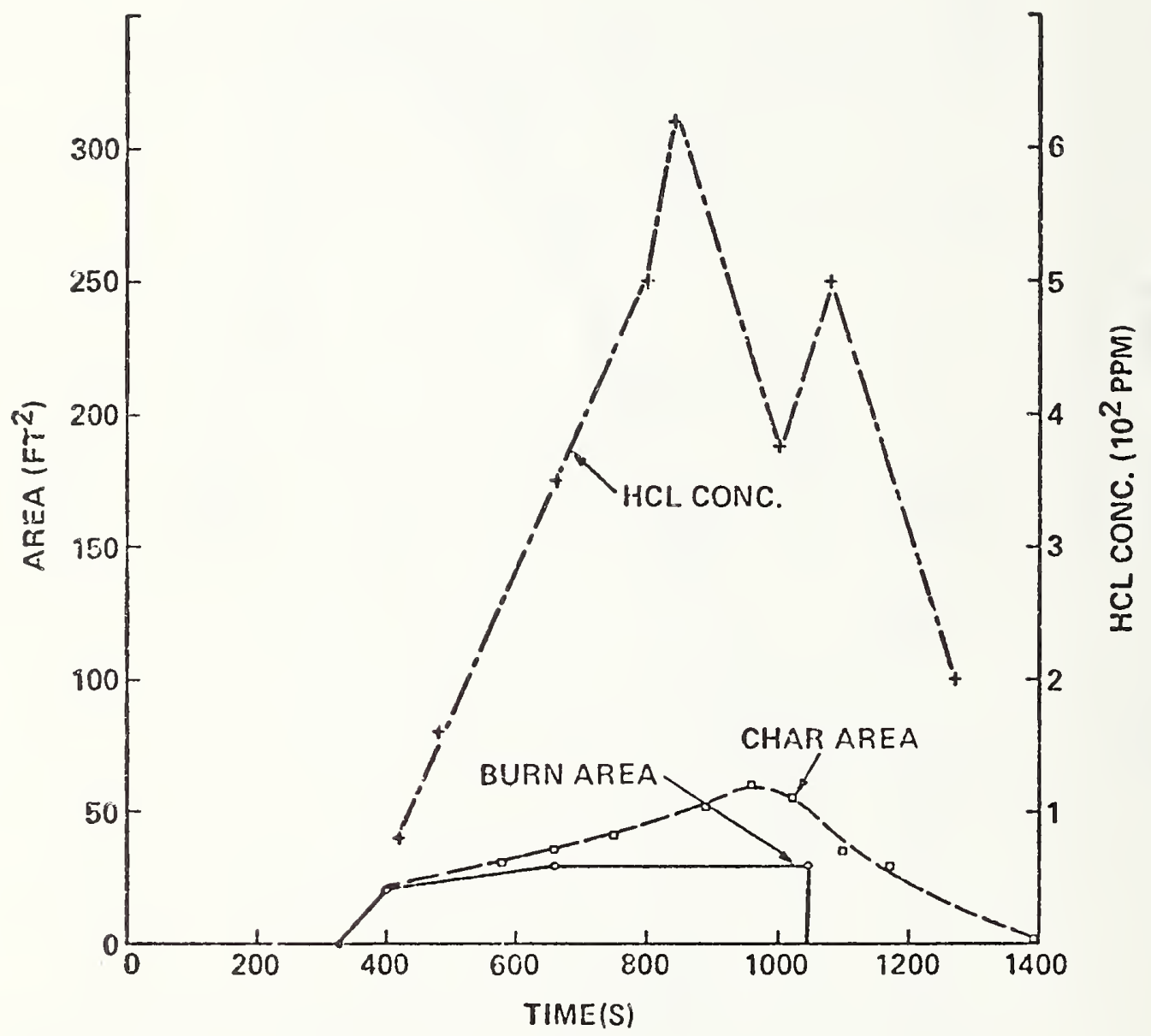

Figure 5a. Burn and char area with $H \dot{C} 1$ concentration (experiment 346). $\left(1 \mathrm{ft}^{2}=0.0929 \mathrm{~m}^{2}\right)$ 


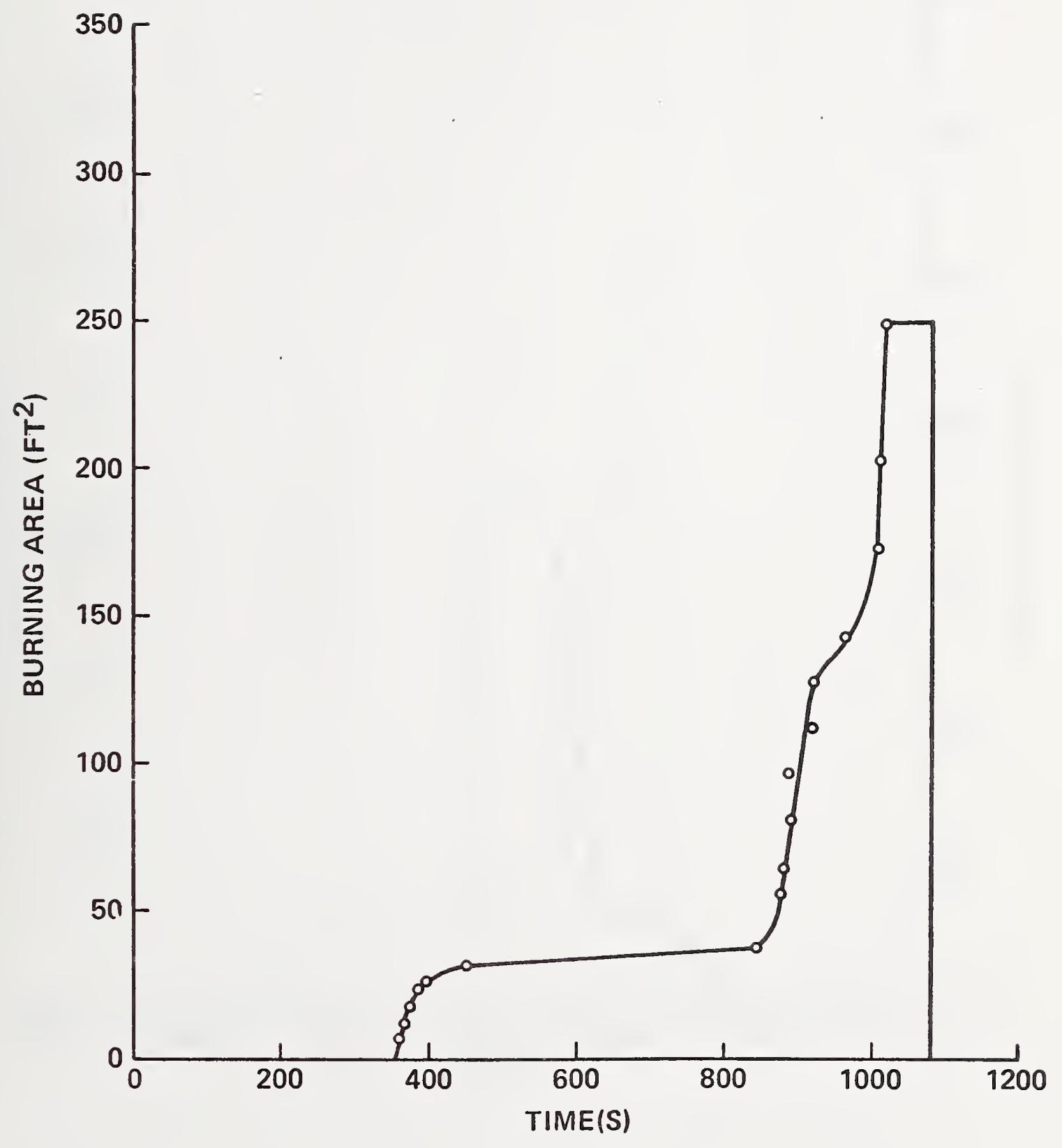

Figure 5b. Burn area (experiment 347). ( $\left.1 \mathrm{ft}^{2}=0.0929 \mathrm{~m}^{2}\right)$ 


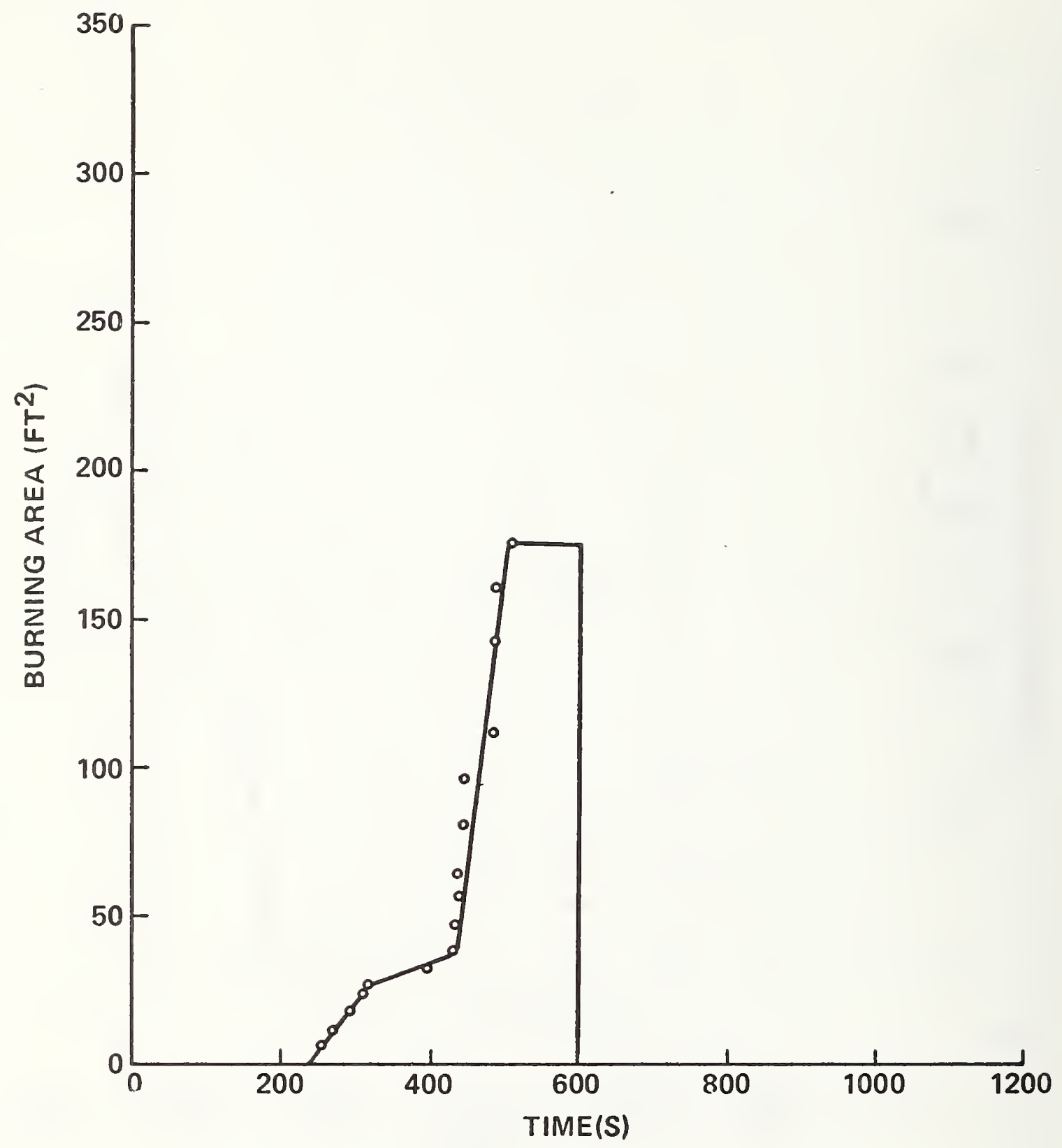

Figure 5c. Burn area (experiment 348). (1 $\left.\mathrm{ft}^{2}=0.0929 \mathrm{~m}^{2}\right)$ 


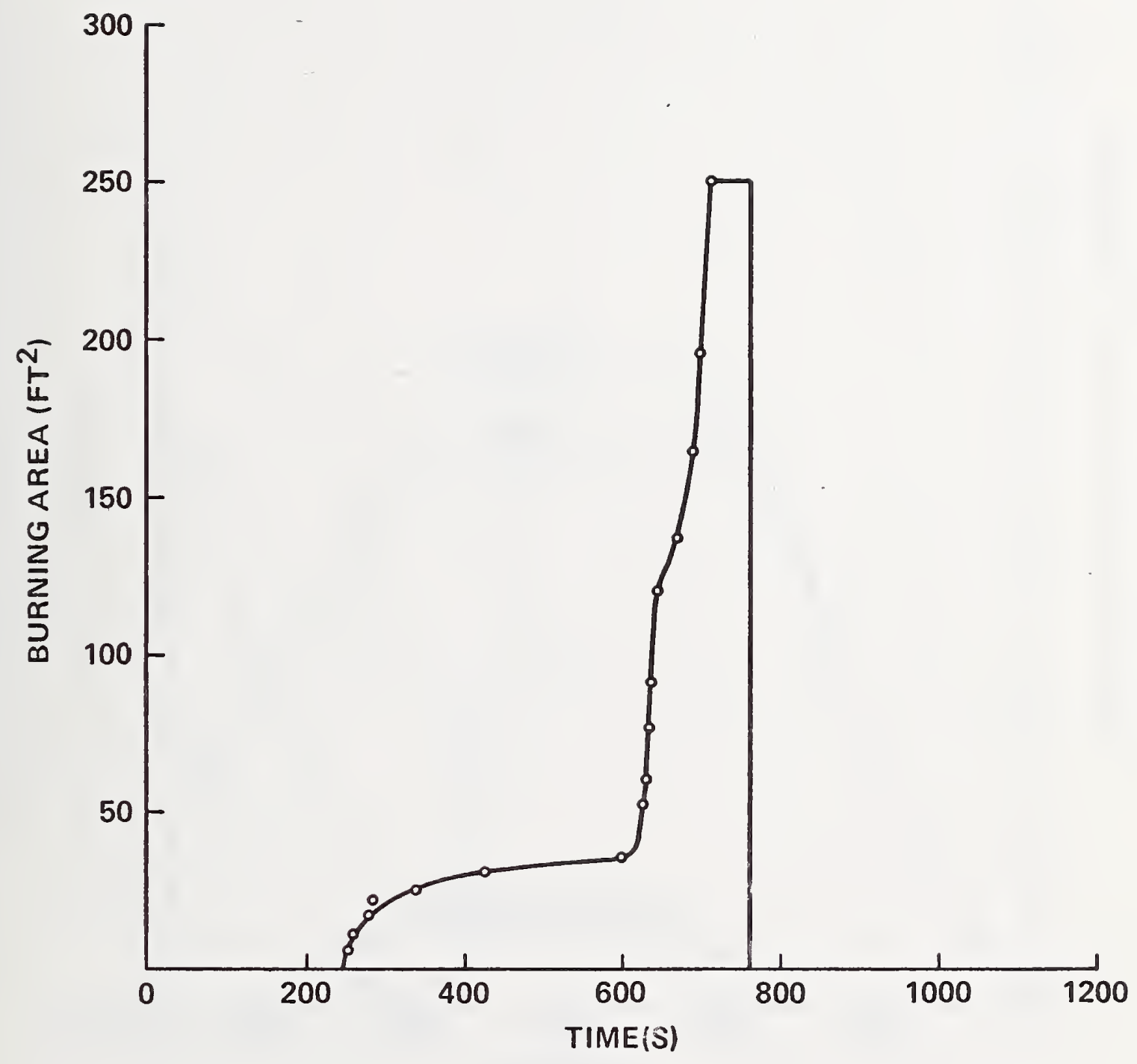

Figure 5d. Burn area (experiment 349). $\left(1 \mathrm{ft}^{2}=0.0929 \mathrm{~m}^{2}\right)$ 


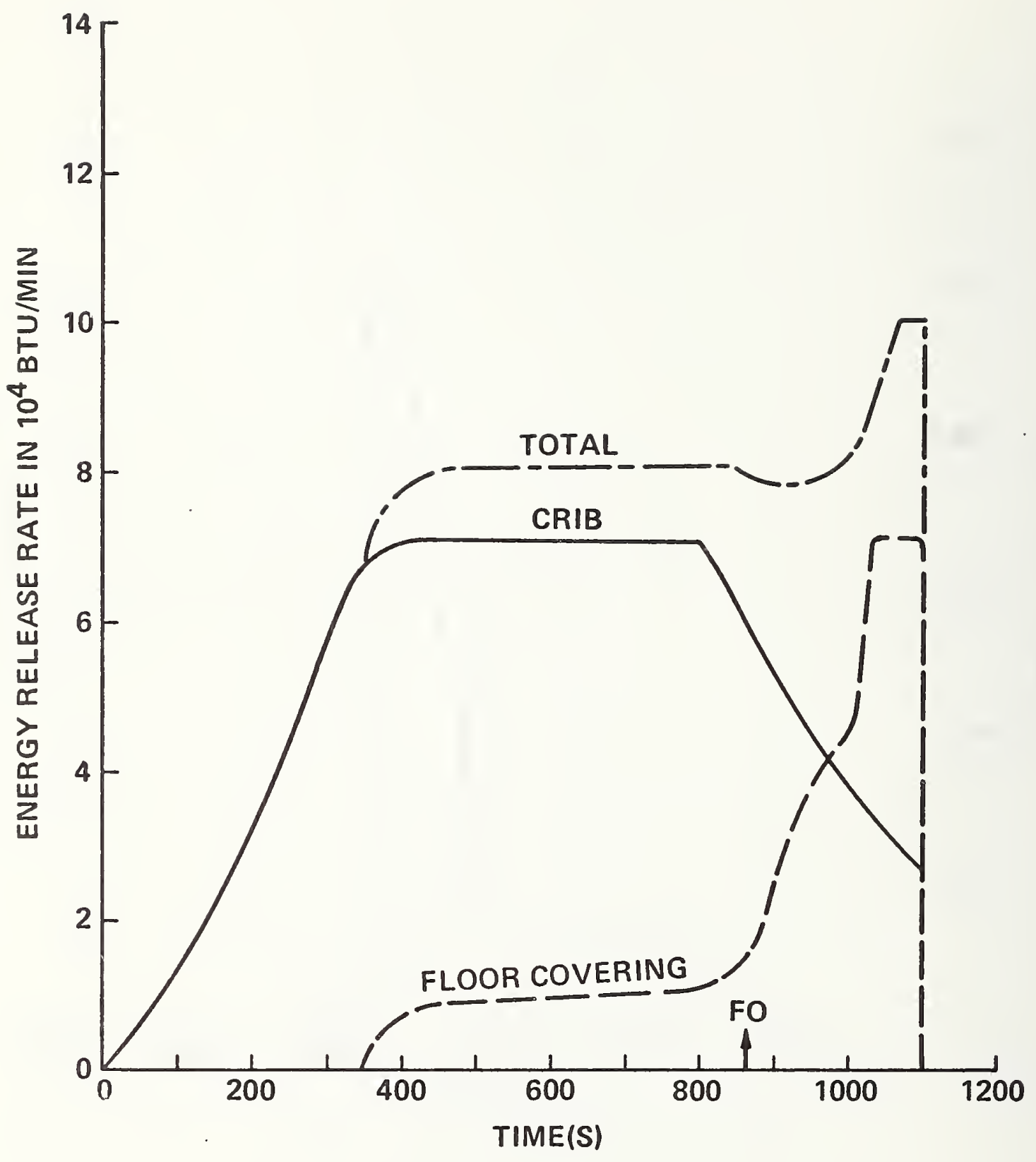

Figure 6a. Energy release rate (experiment 347$).(1 \mathrm{Btu} / \mathrm{min}=17.57 \mathrm{~W})$ 54 


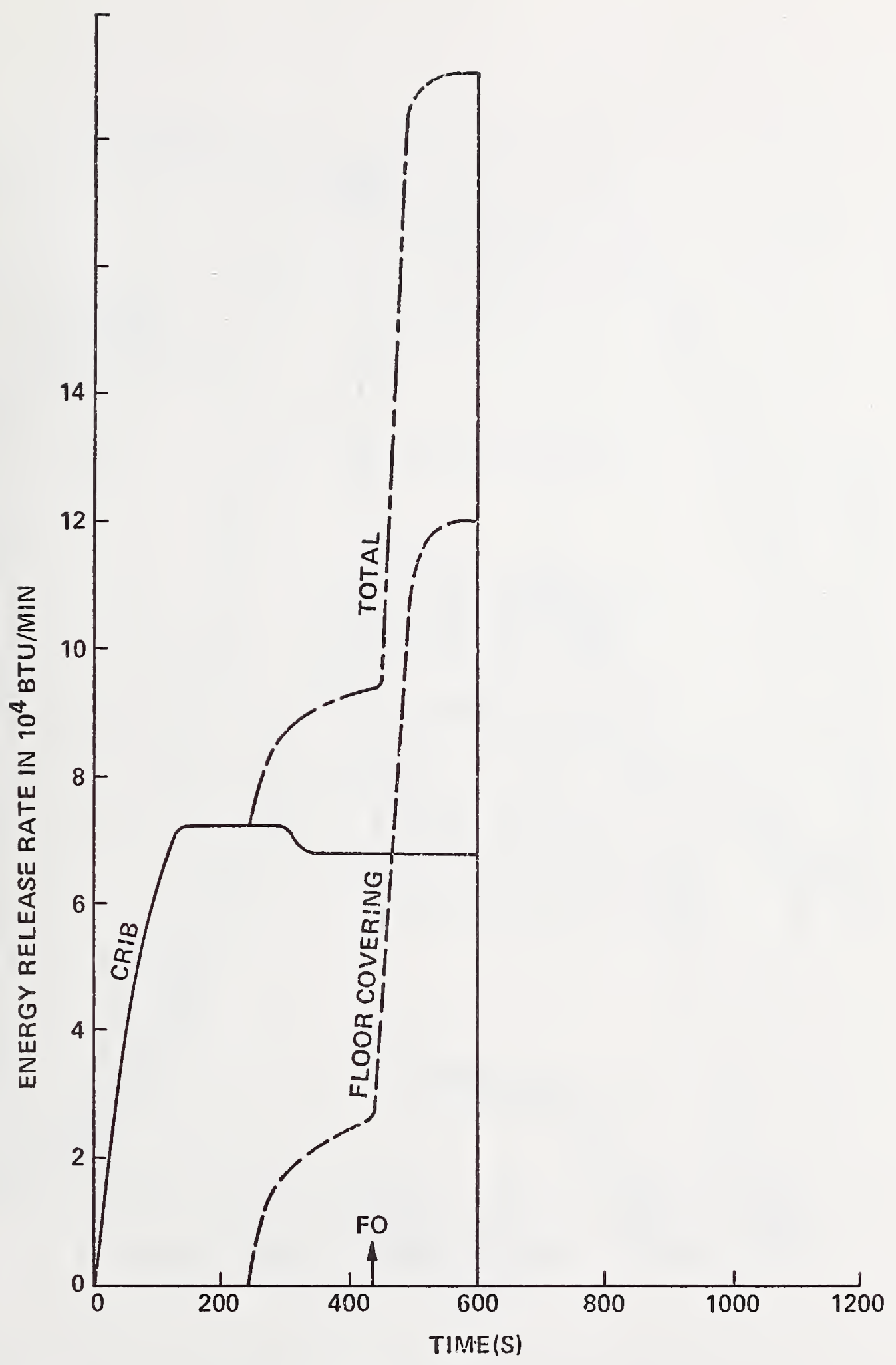

Figure 6b. Energy release rate (experiment 348$).(1 \mathrm{Btu} / \mathrm{min}=17.57 \mathrm{~W})$ 


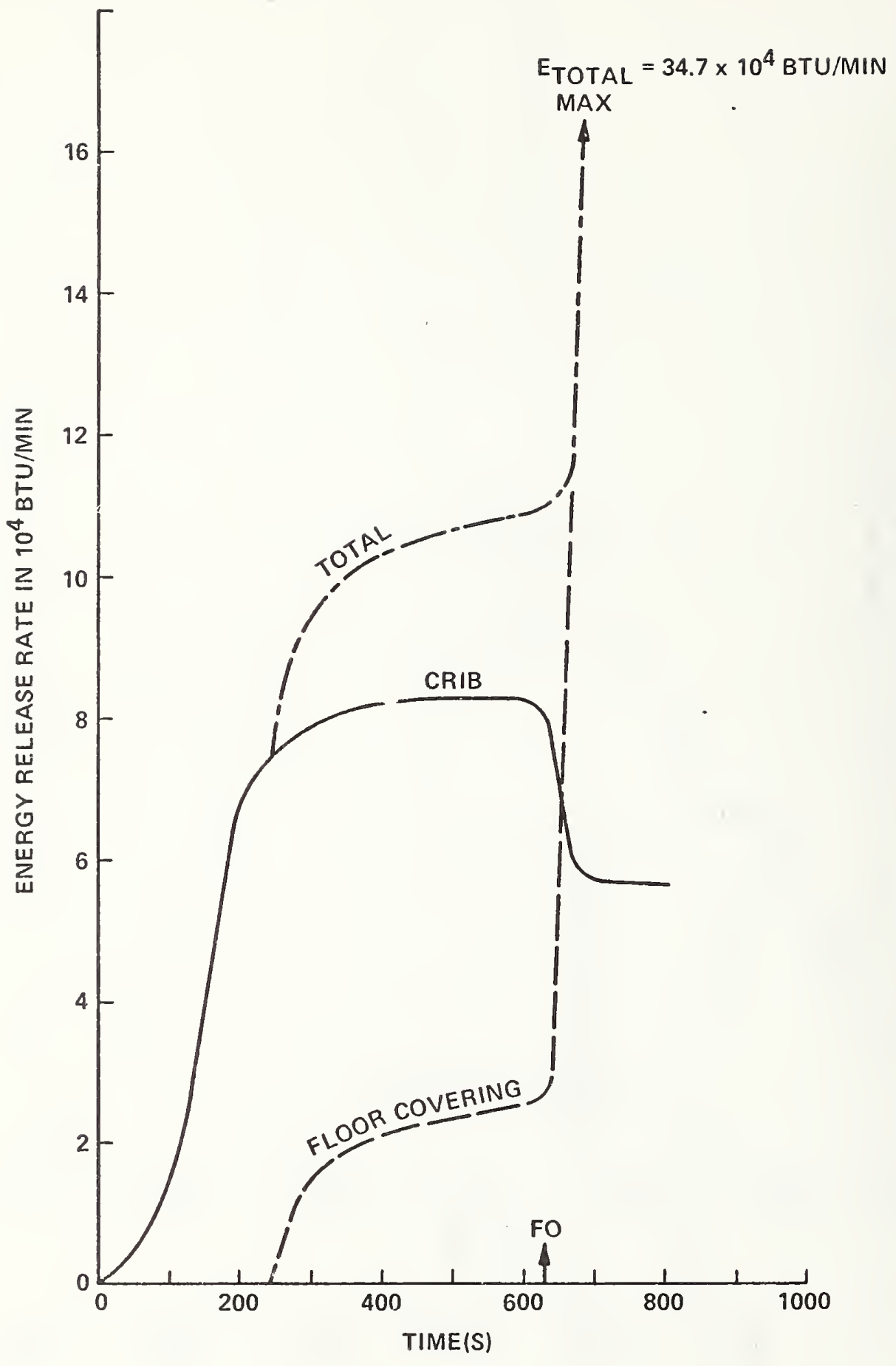

Figure 6c. Energy release rate (experiment 347$).(1 \mathrm{Btu} / \mathrm{min}=17.57 \mathrm{~W})$. 


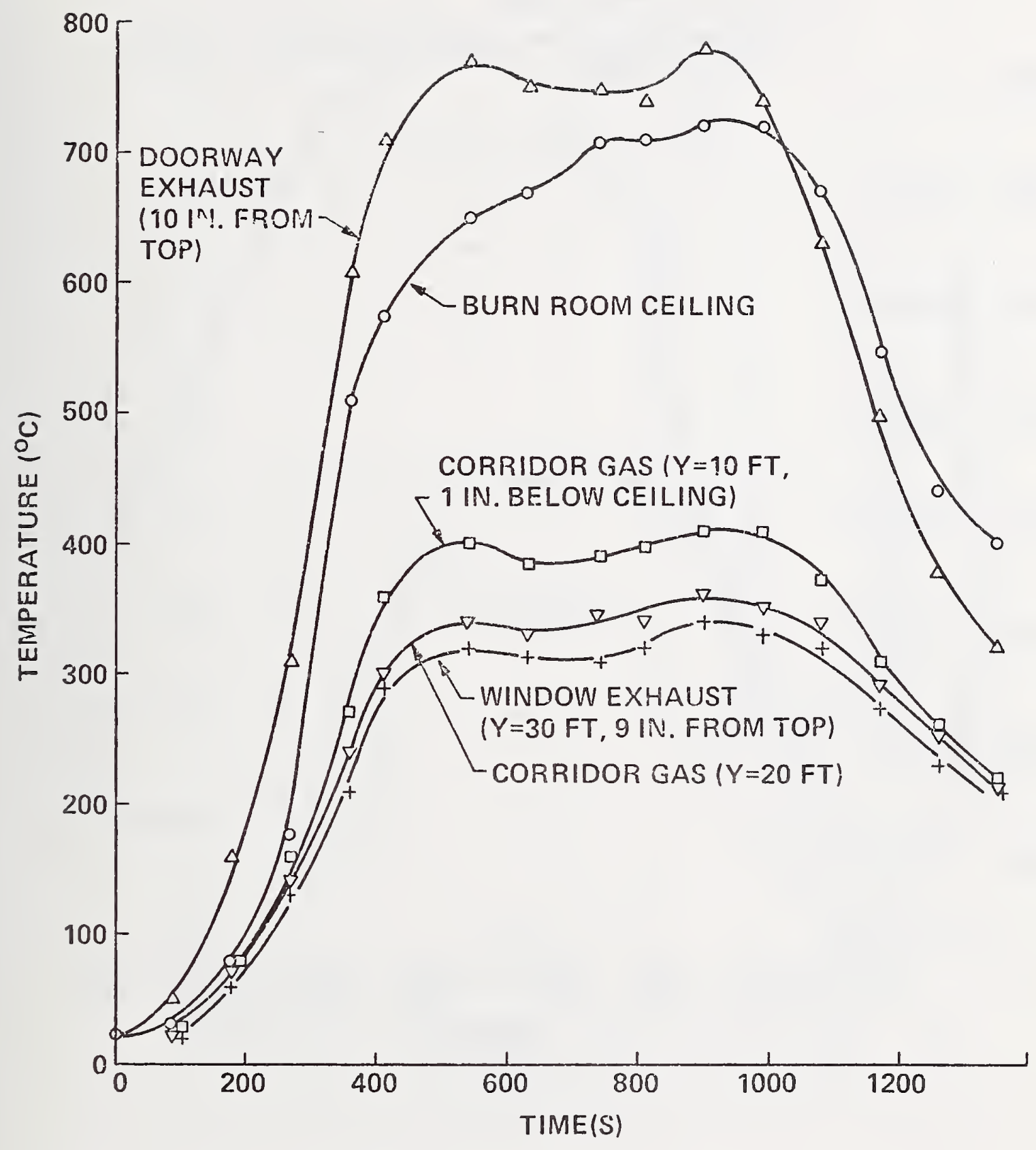

Figure 7. Combustion products temperature at locations downstream of fire (Experiment 346). 


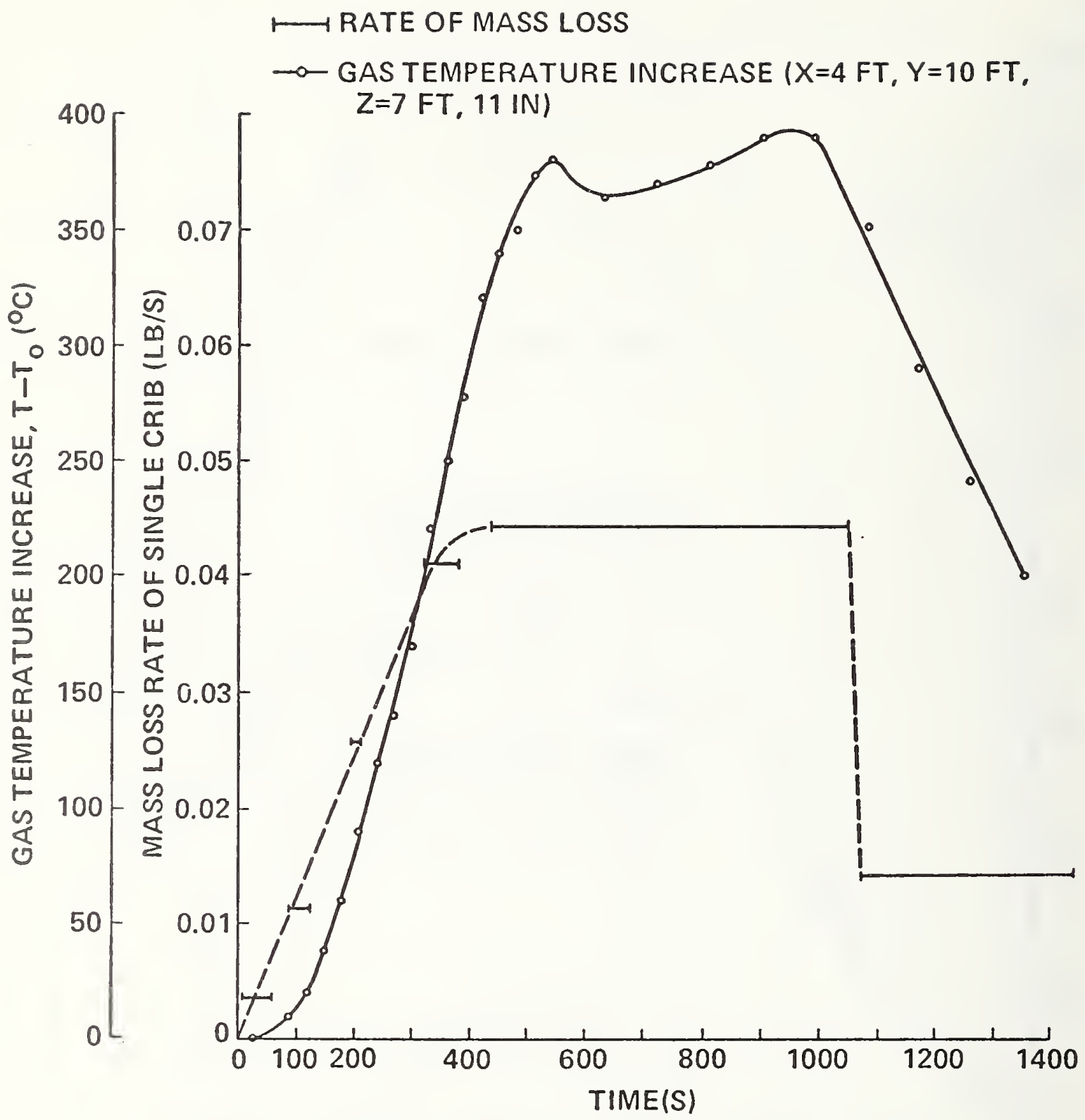

Figure 8a. Crib weight loss rate compared with corridor gas temperature at $X=4 \mathrm{ft}, Y=10 \mathrm{ft}, Z=7 \mathrm{ft} 11$ in (experiment 346$).(1 \mathrm{lb} / \mathrm{s}=$ $0.4536 \mathrm{~kg} / \mathrm{s}, 1 \mathrm{ft}=0.3048 \mathrm{~m}, 1$ in $=0.0254 \mathrm{~m}$ ) 


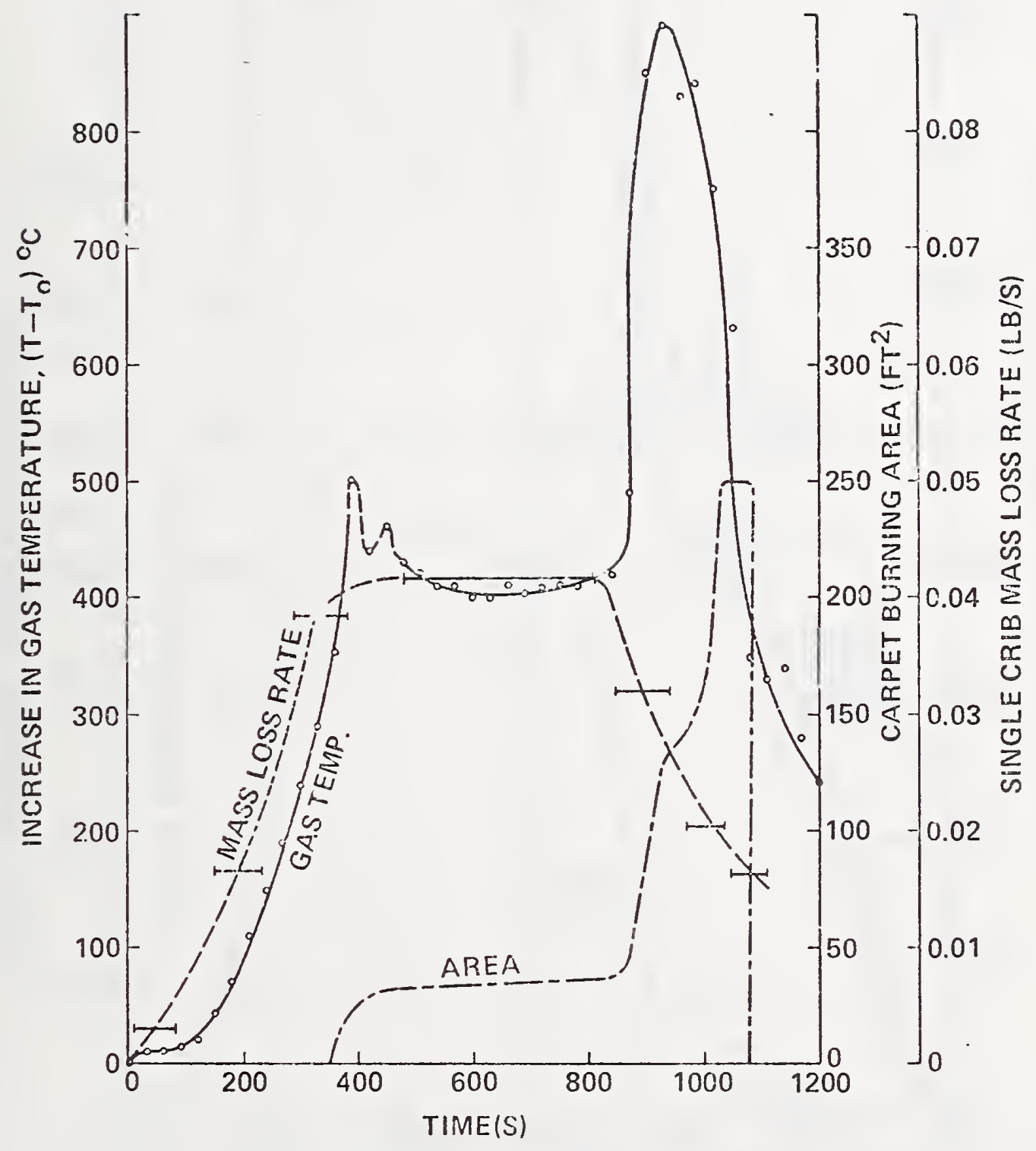

Figure 8b. Crib weight loss rate, gas temperature $(X=4 \mathrm{ft}, Y=10 \mathrm{ft}$, $\mathrm{Z}=7 \mathrm{ft} 11 \mathrm{in})$, and burn area (experiment 347$).(1 \mathrm{lb} / \mathrm{s}=0.4536 \mathrm{~kg} / \mathrm{s}$, $1 \mathrm{ft}^{2}=0.0929 \mathrm{~m}^{2}, 1 \mathrm{ft}=0.3048 \mathrm{~m}, 1$ in $=0.0254 \mathrm{~m}$ ) 


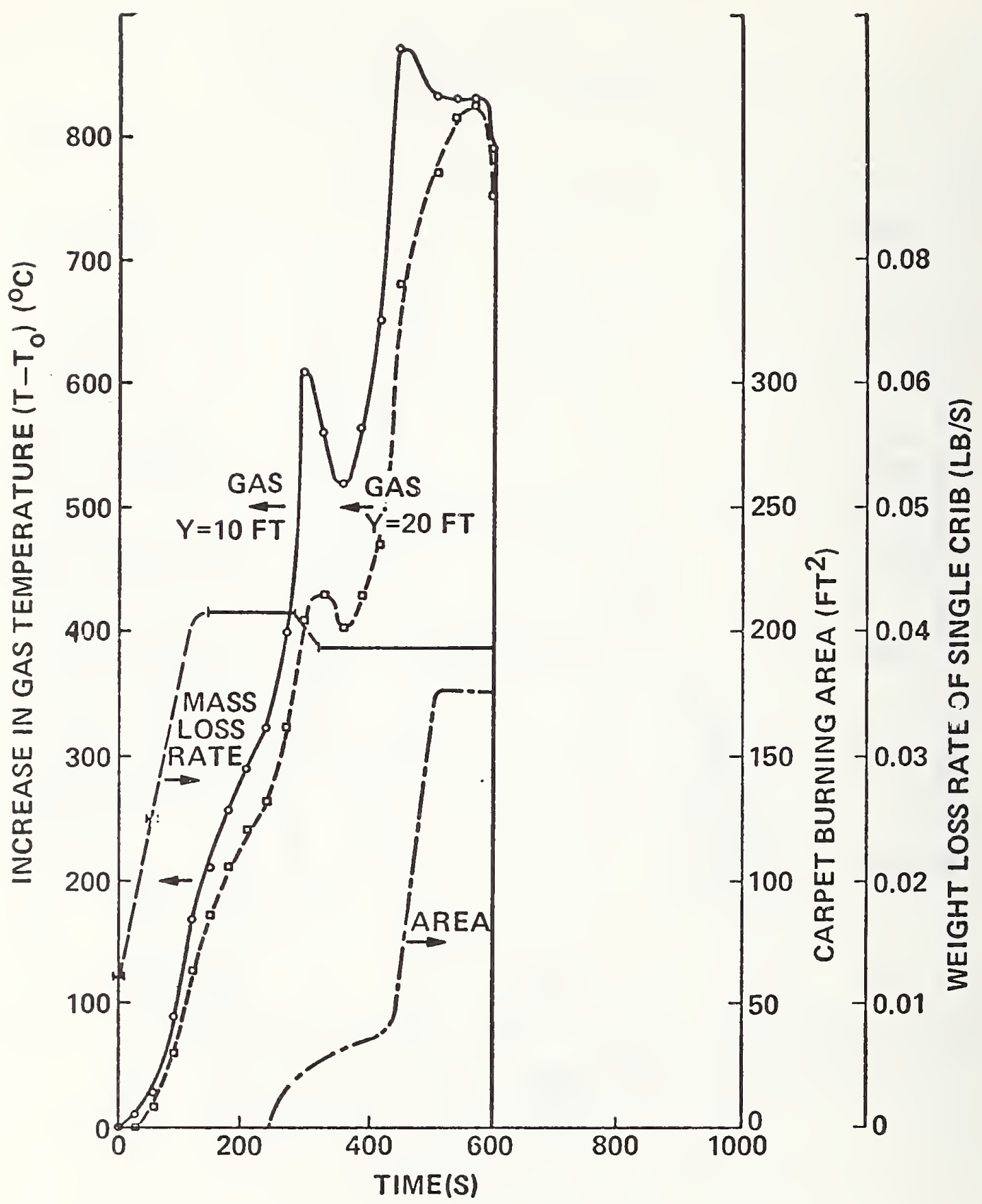

Figure 8c. Crib weight loss rate, gas temperature ( $X=4 \mathrm{ft}, Y=10 \mathrm{ft}$, $\mathrm{Z}=7 \mathrm{ft} 11 \mathrm{in})$, and burn area (experiment 348$).(1 \mathrm{lb} / \mathrm{s}=0.4536 \mathrm{~kg} / \mathrm{s}$, $1 \mathrm{ft}^{2}=0.0929 \mathrm{~m}^{2}, 1 \mathrm{ft}=0.3048 \mathrm{~m}, 1$ in $=0.0254 \mathrm{~m}$ ) 


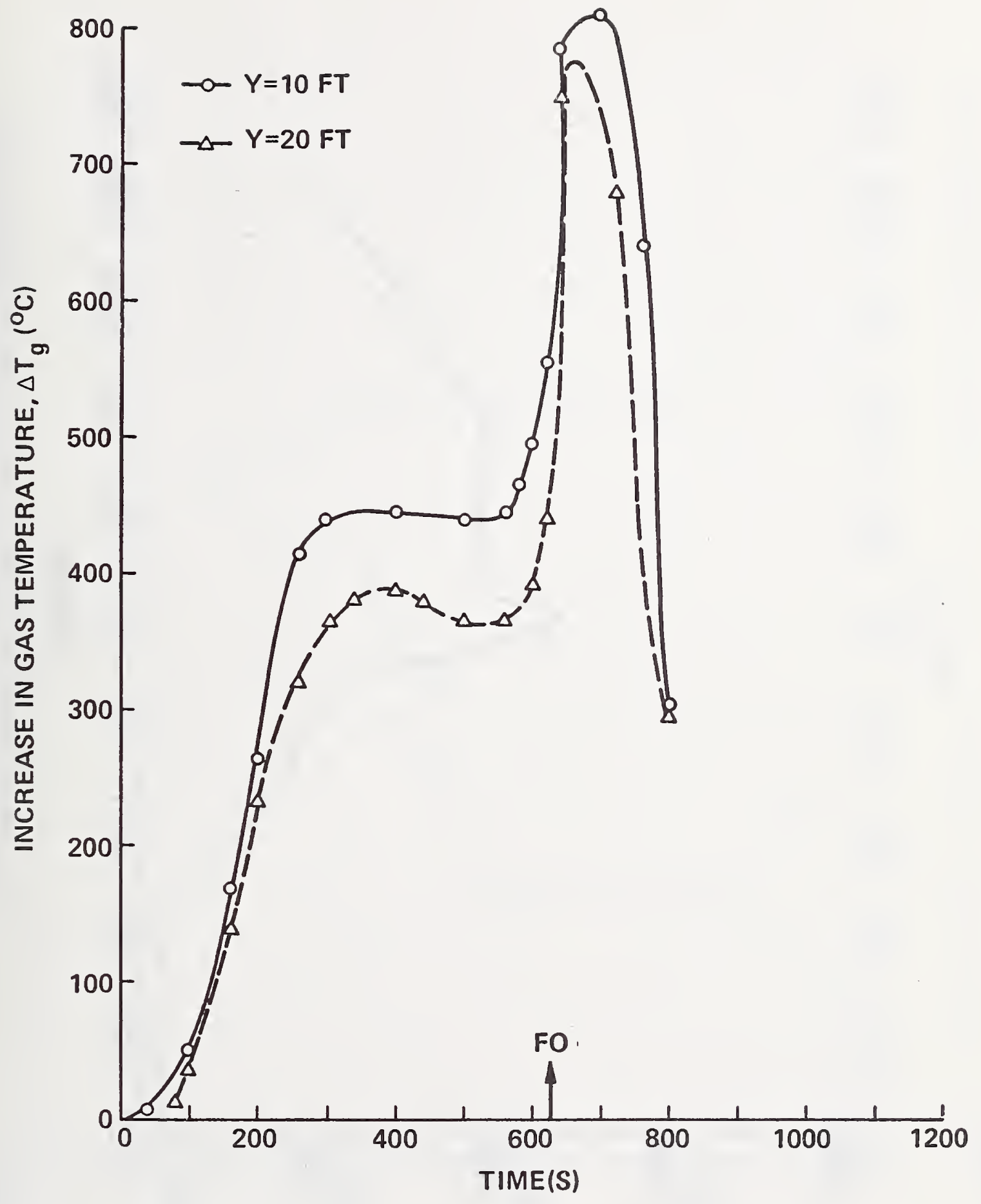

Figure 8d. Corridor gas temperatures 1 . inch $(2.54 \mathrm{~cm})$ below the ceiling at $Y=10 \mathrm{ft}(3.05 \mathrm{~m})$ and $Y=20 \mathrm{ft}(6.1 \mathrm{~m})$ (experiment 349$)$. 


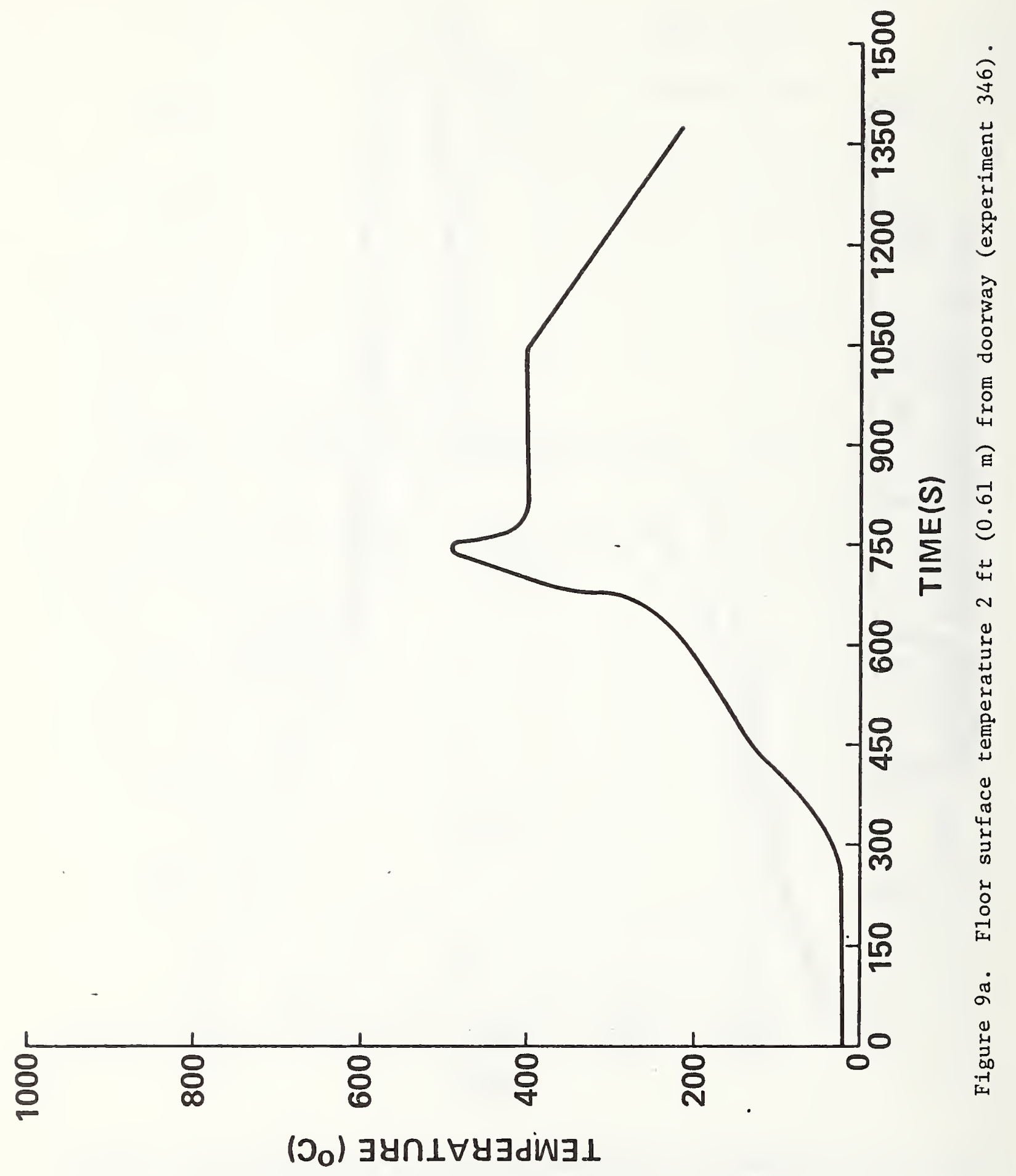




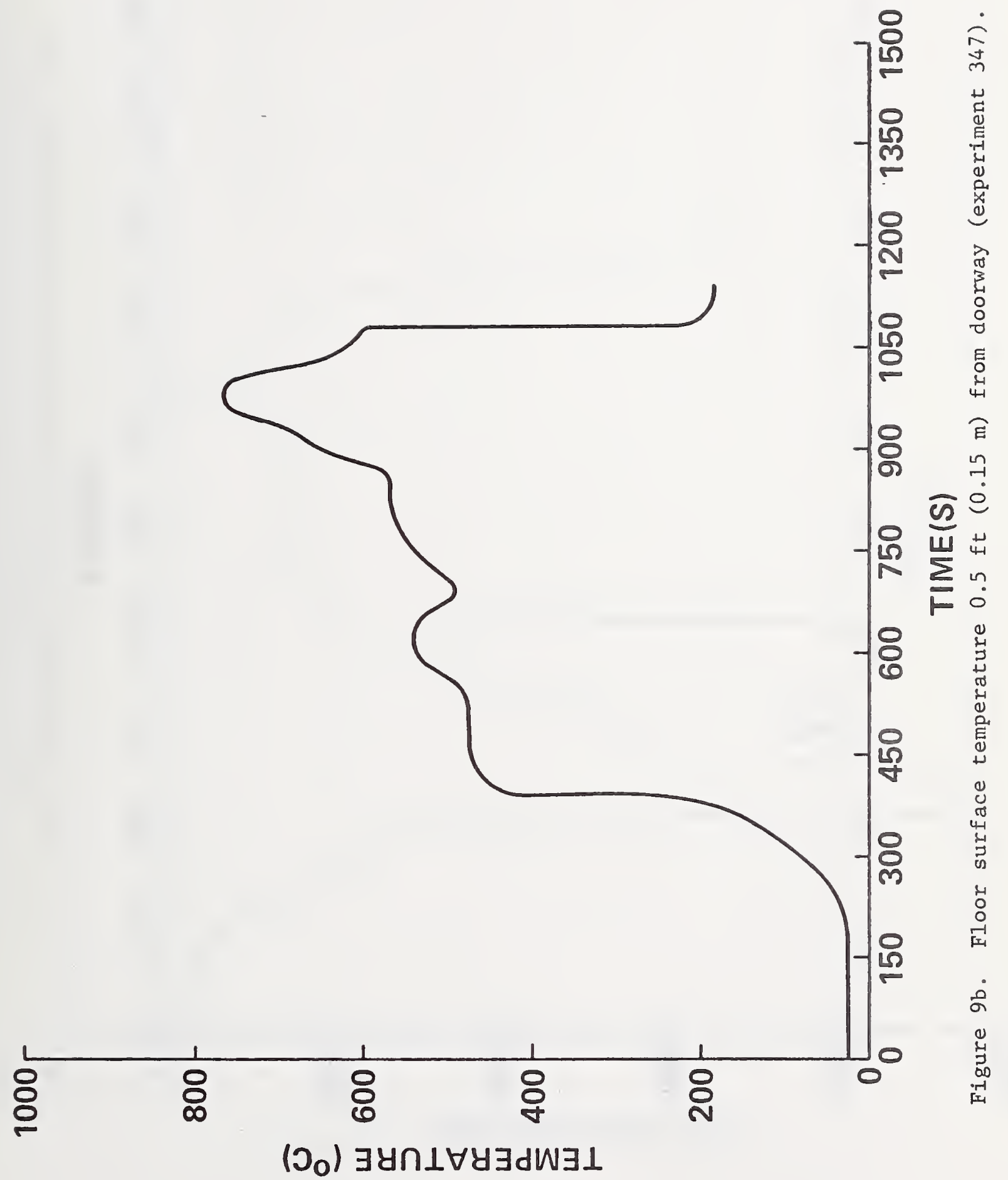




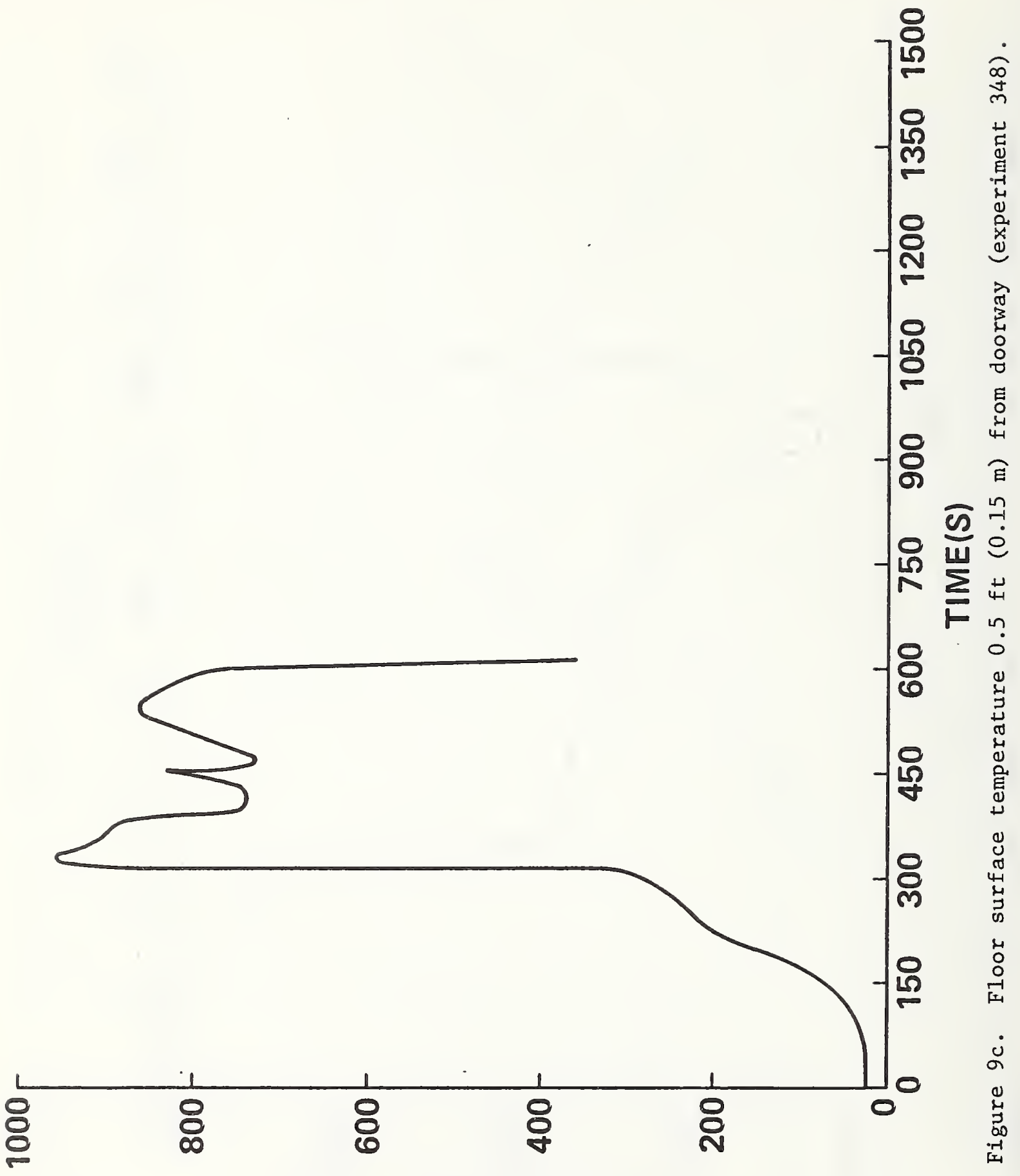

(ग) $\exists y \cap \perp \forall y \exists d W \exists \perp$ 


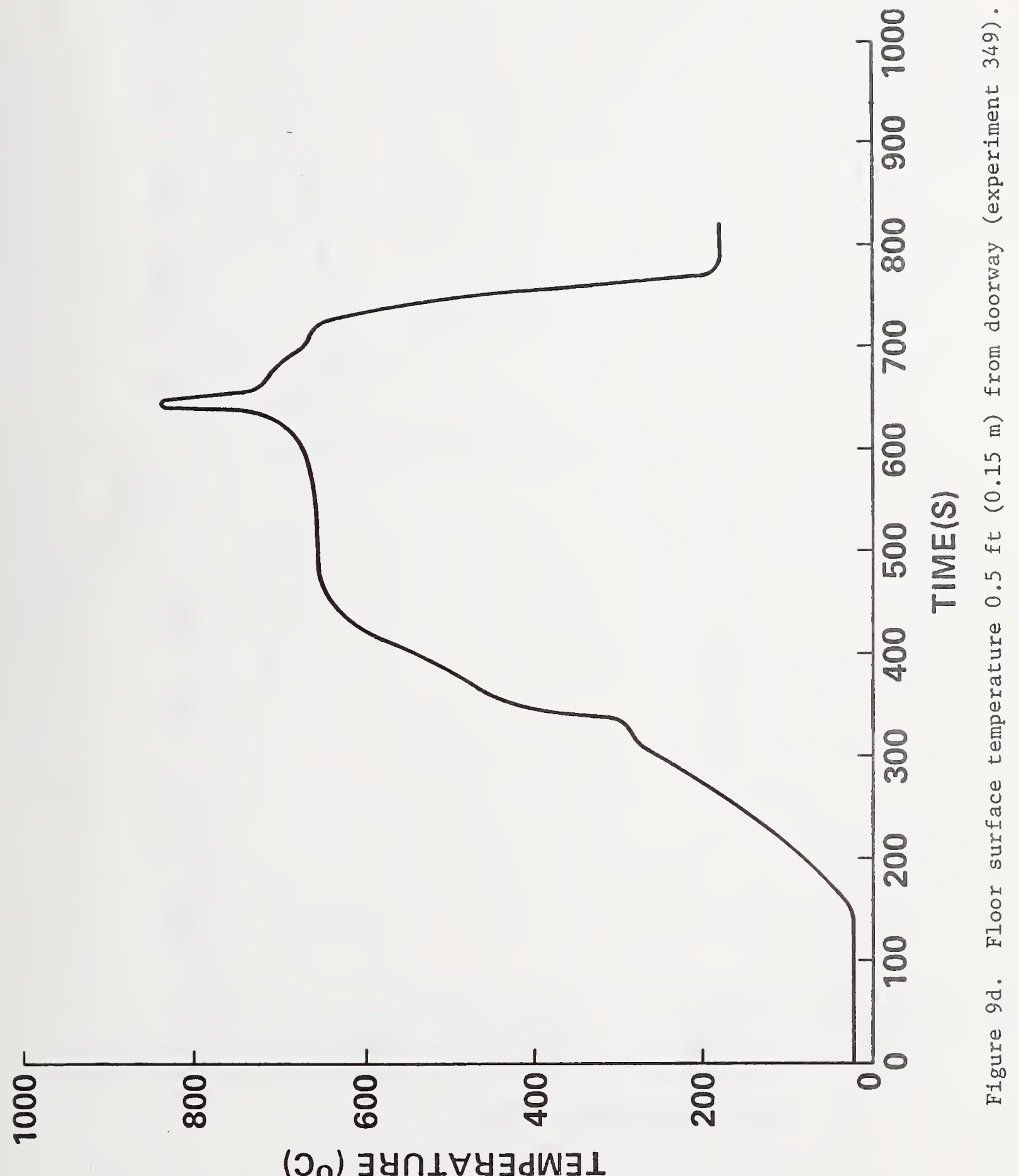

$\left(\supset_{0}\right) \exists y \cap \perp \forall y \exists d W \exists \perp$ 


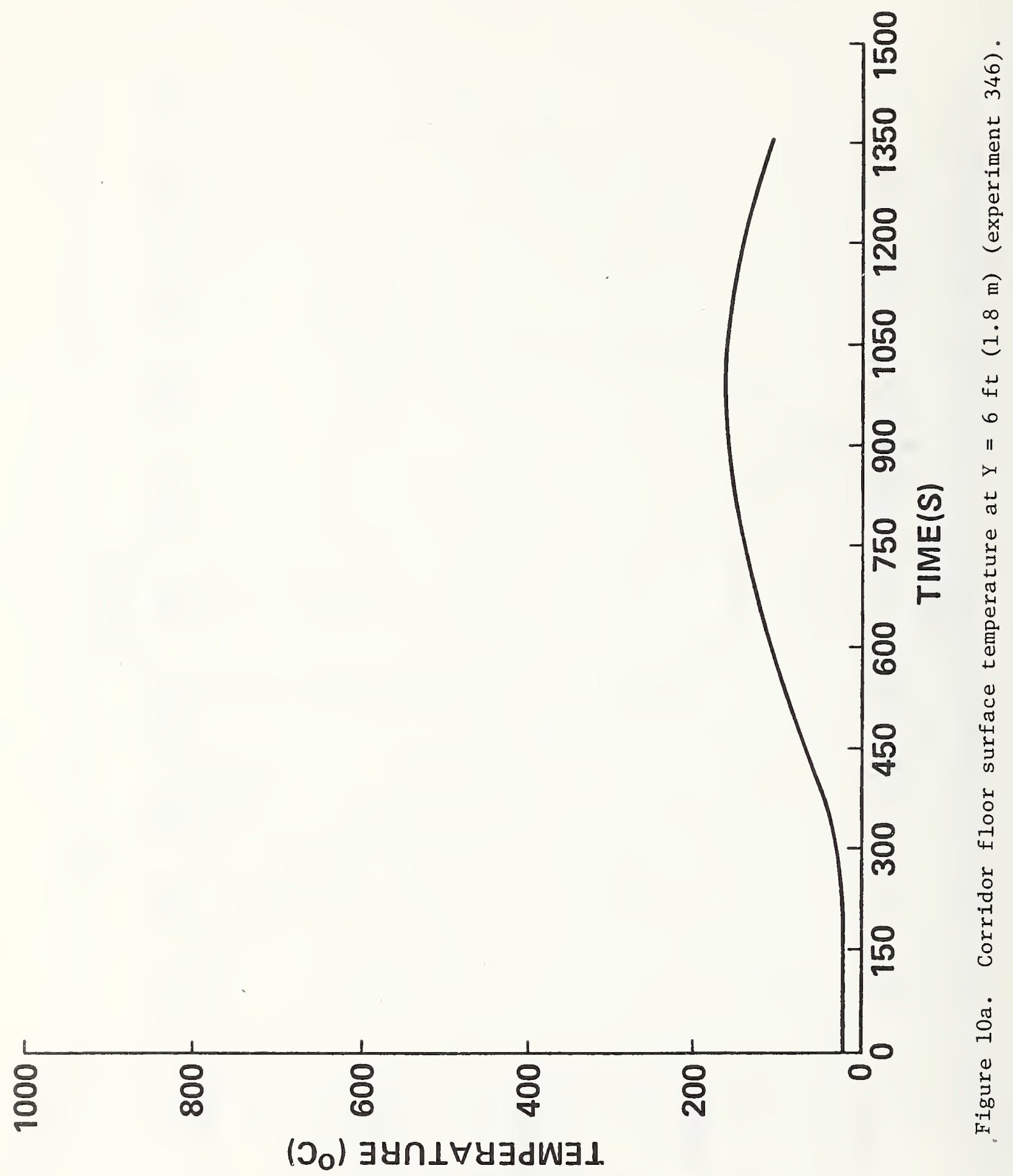




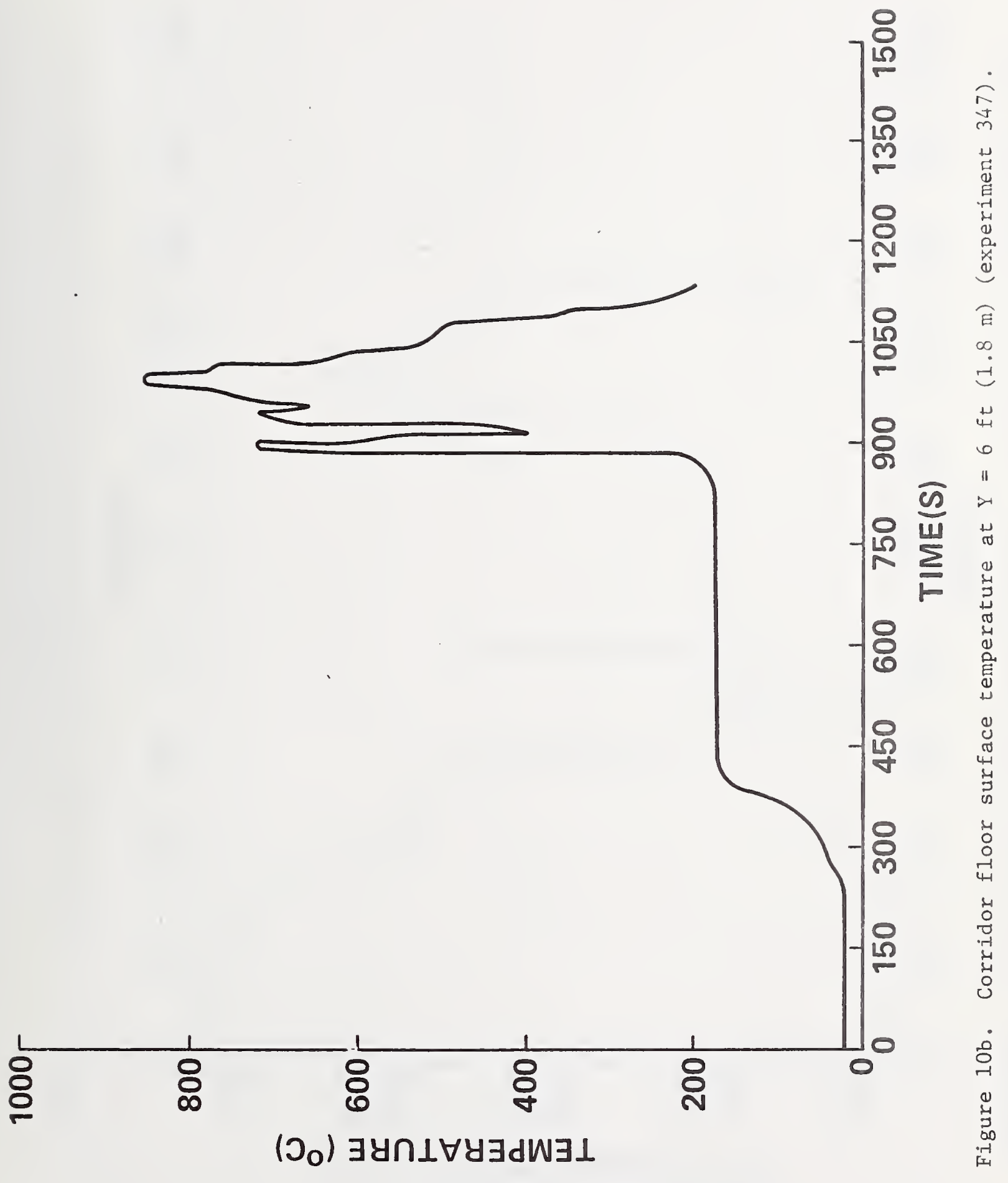




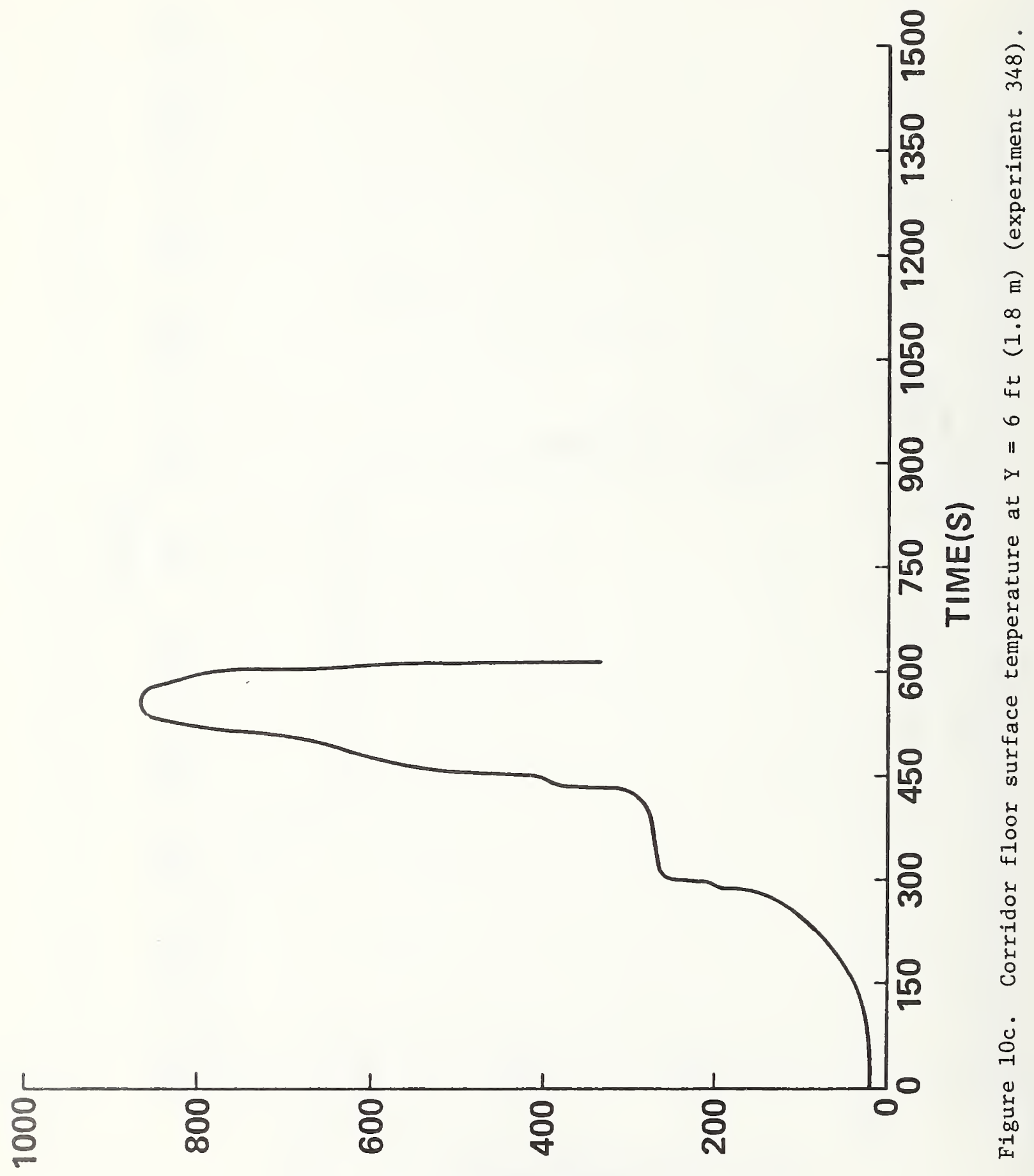

$\left(\supset_{0}\right) \exists y \cap \perp \forall y \exists d W \boxminus \boxminus \perp$ 


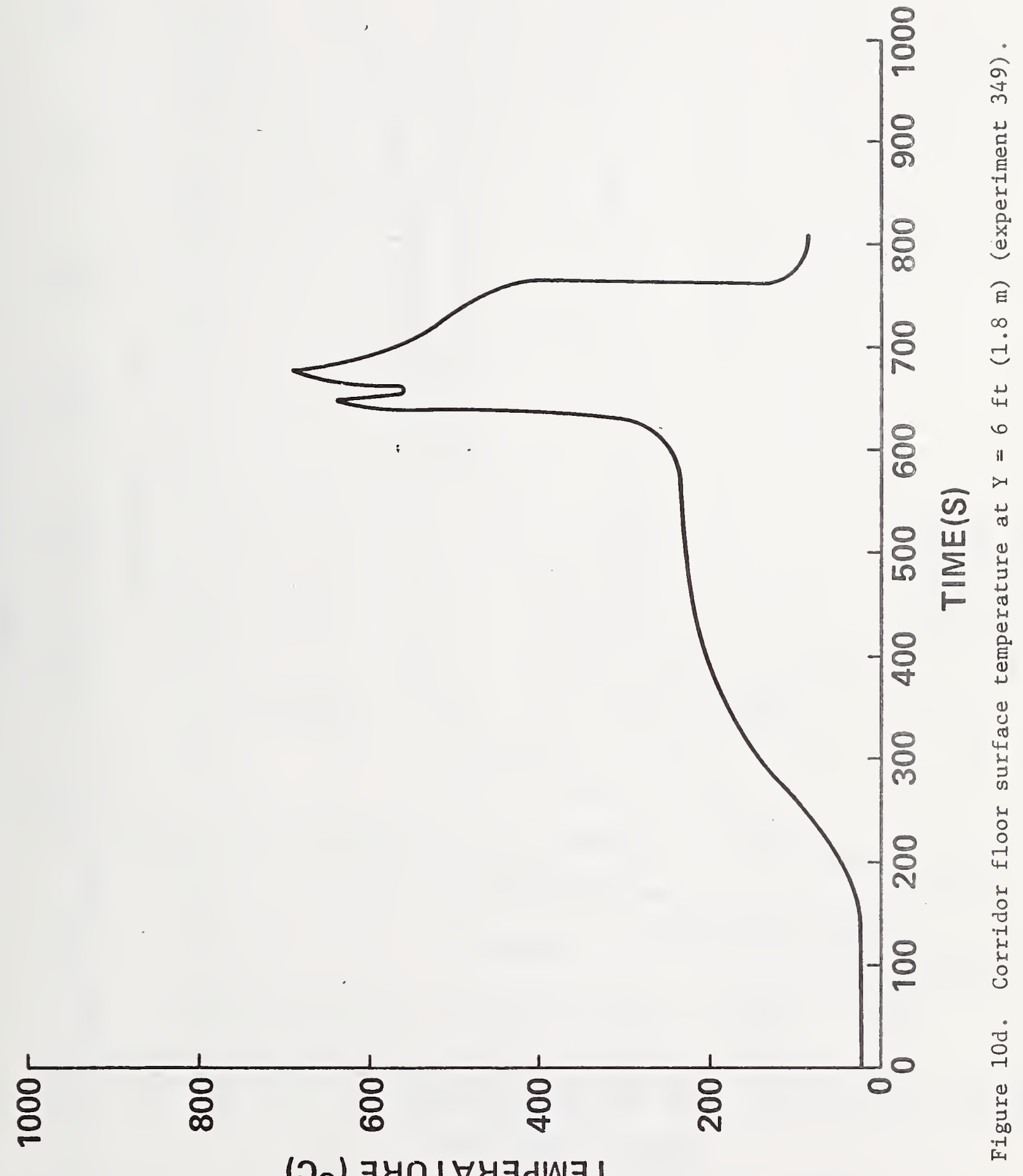

(ग) $\exists y n \perp \forall y \exists d W \exists \perp$ 


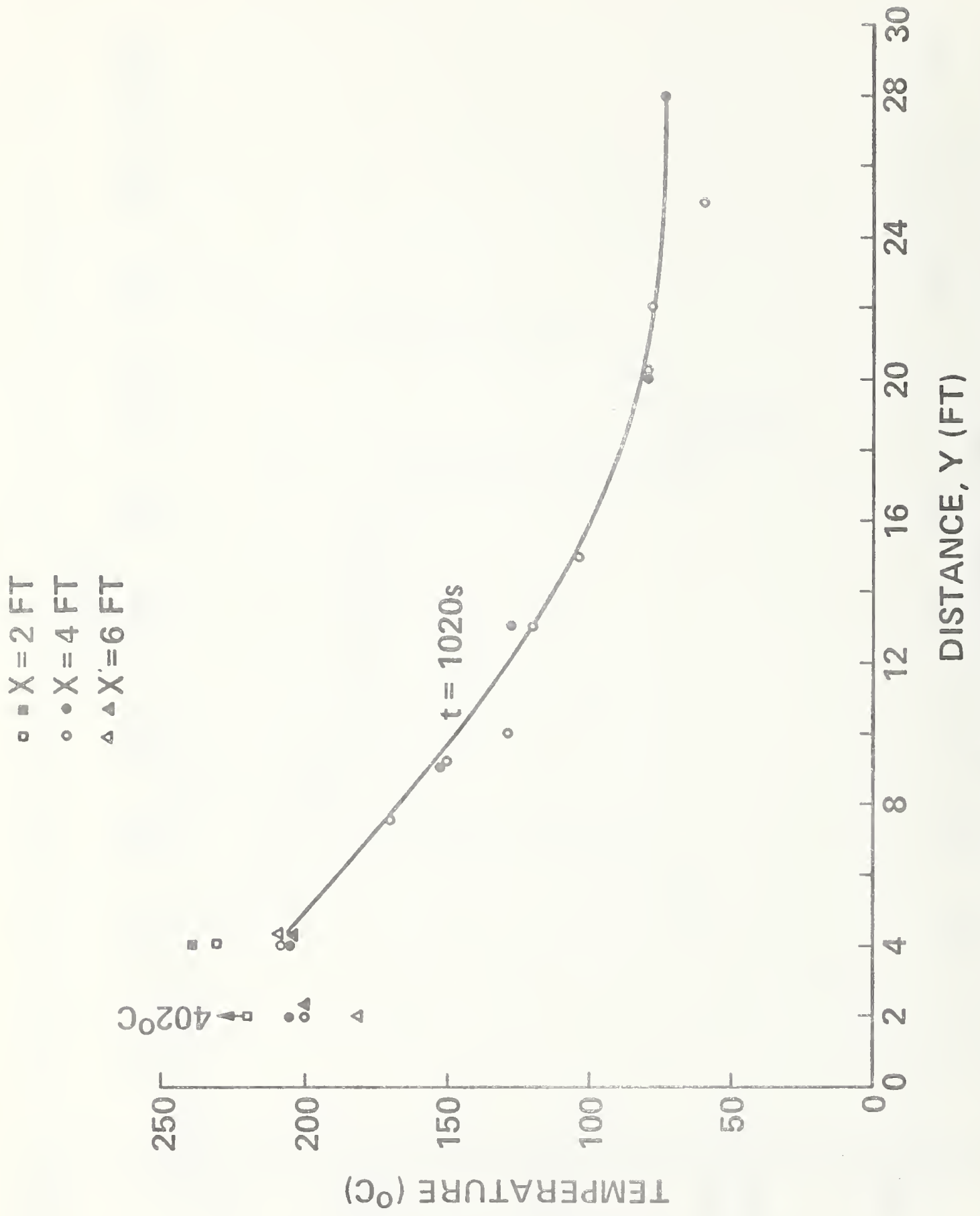

峁

]$^{\infty}$

प्त

莡

운

㟧

농

宣

क $\infty$

고

两。

깅

تี

들

苟.

ธี

-

岁

:

4

$\rightarrow$.

()

.

구 도

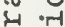

$\omega$

2.

E

㫕

4 U

का

मू

잉

压 毛

-

实

न

()

光

年 


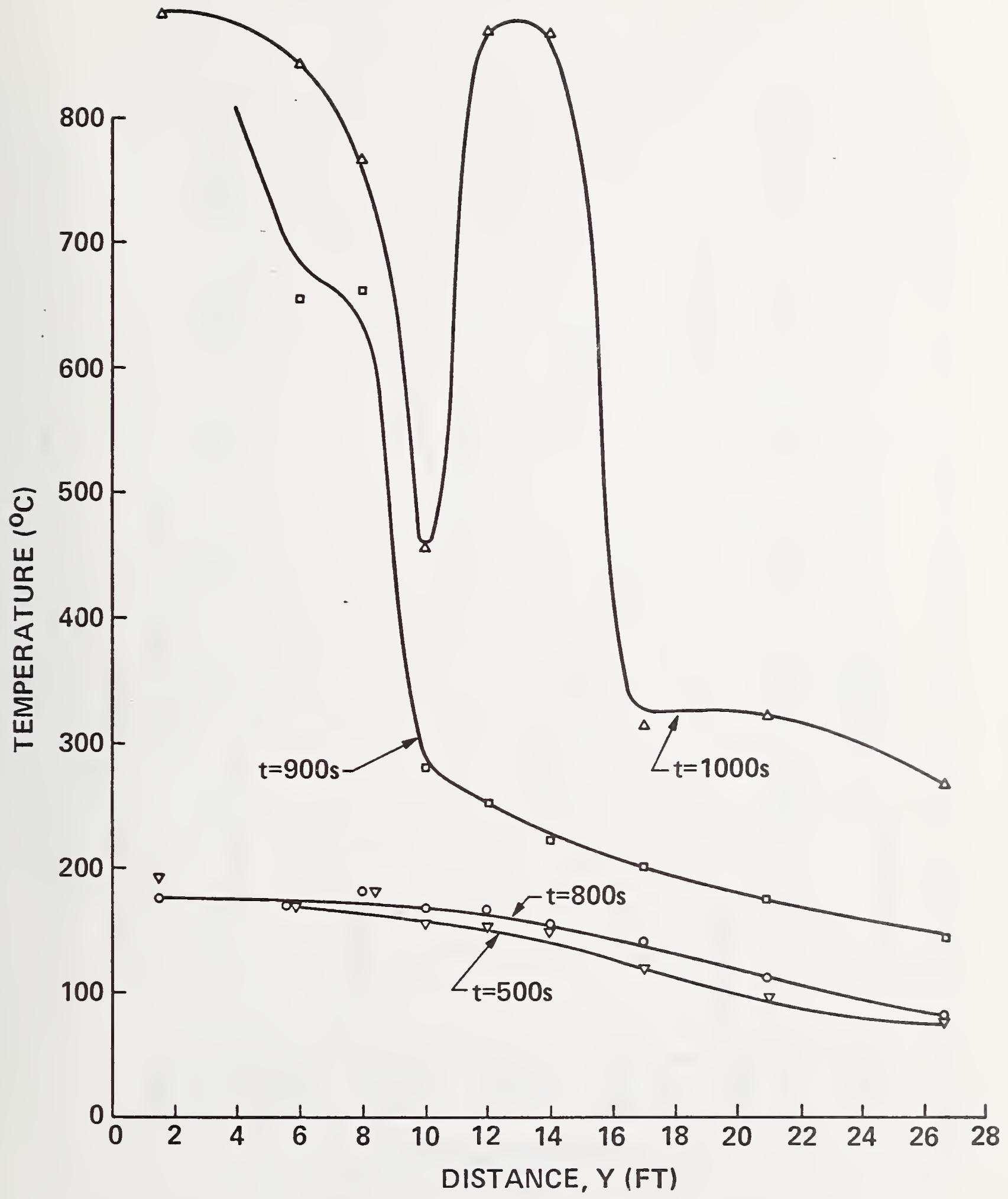

Figure 11b. Floor surface temperature distribution (experiment 347). (1 $\mathrm{ft}=0.3048 \mathrm{~m})$ 


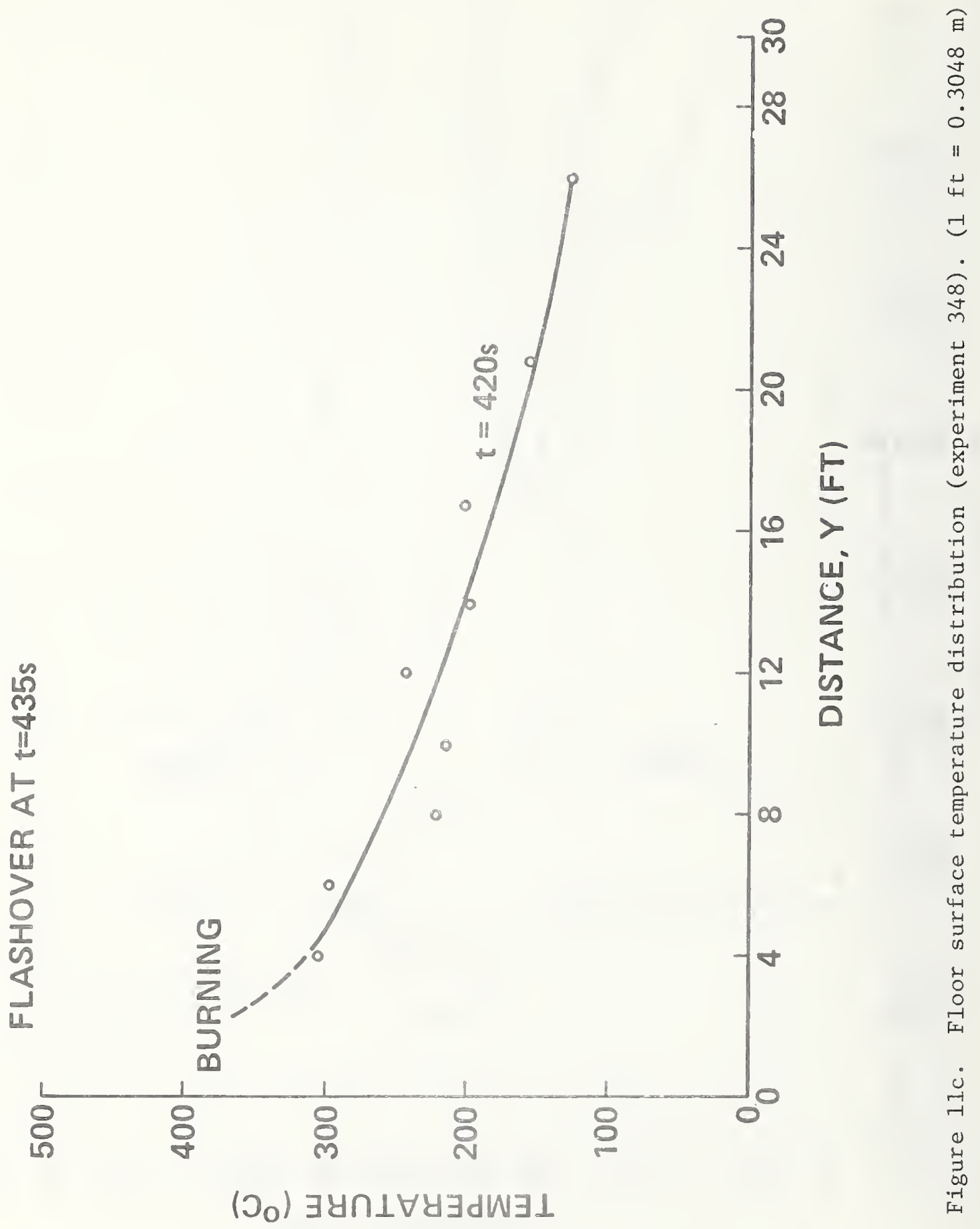




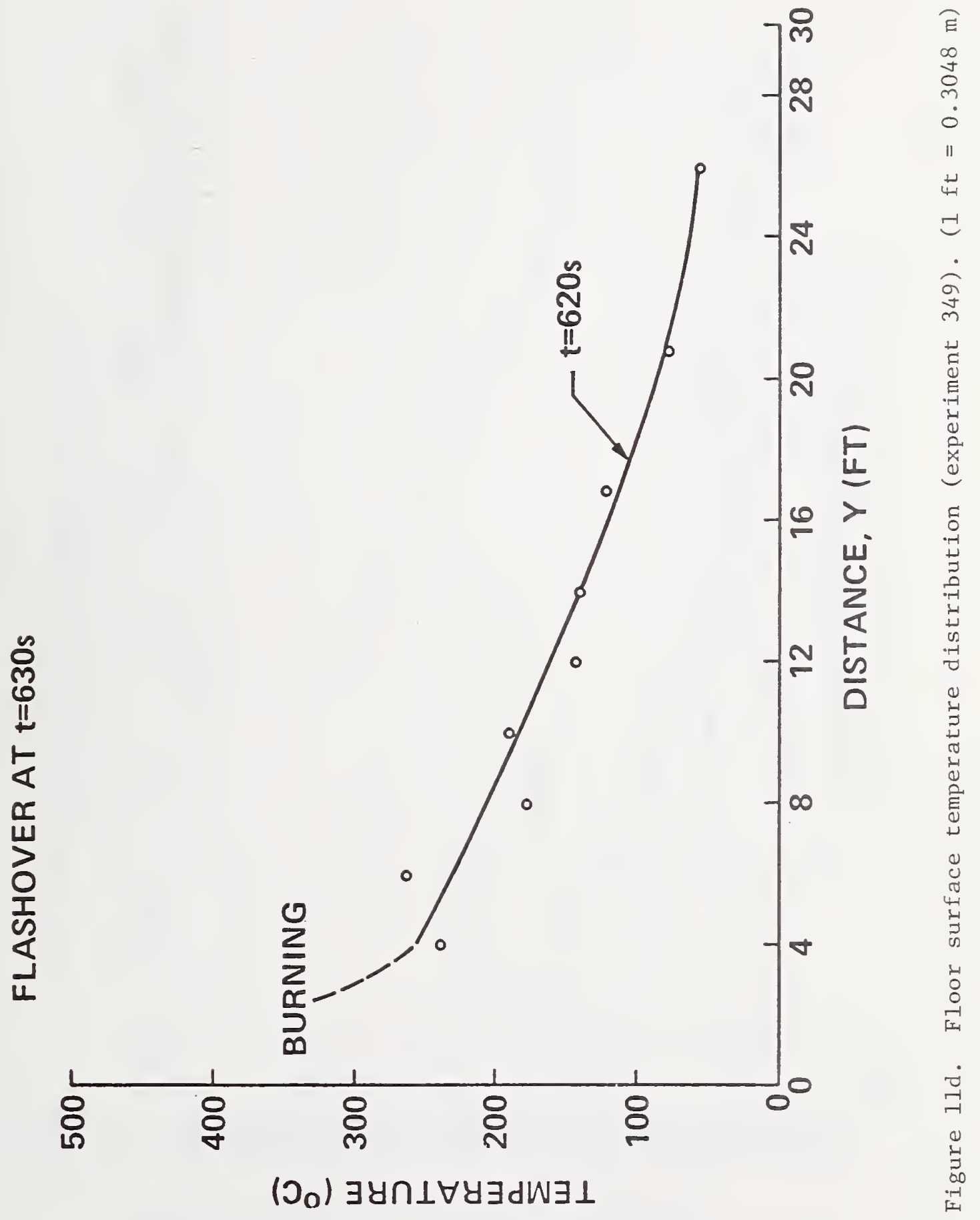




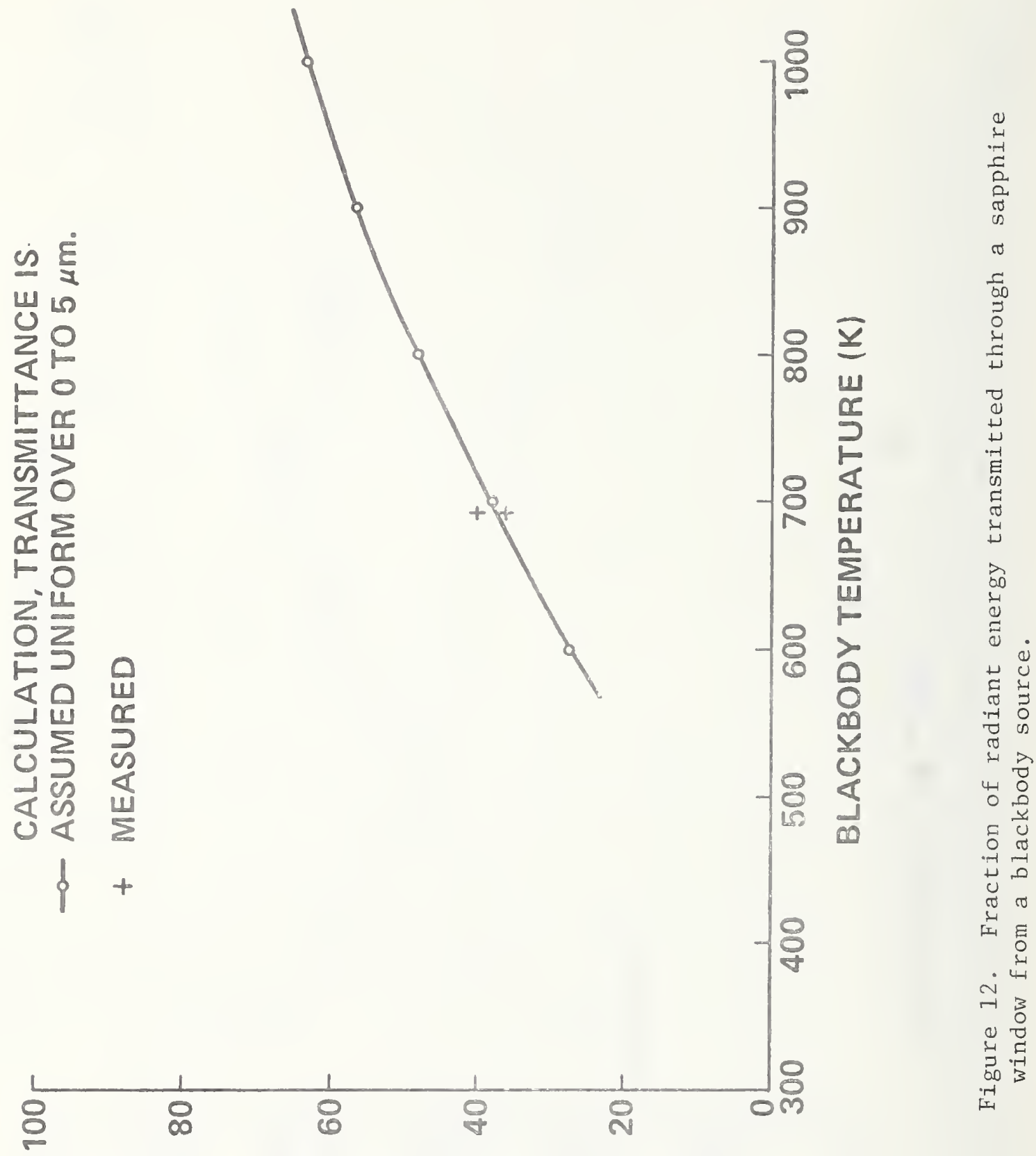

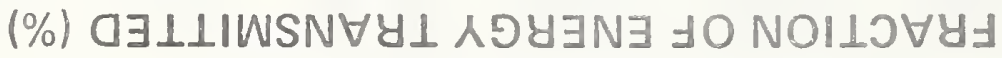




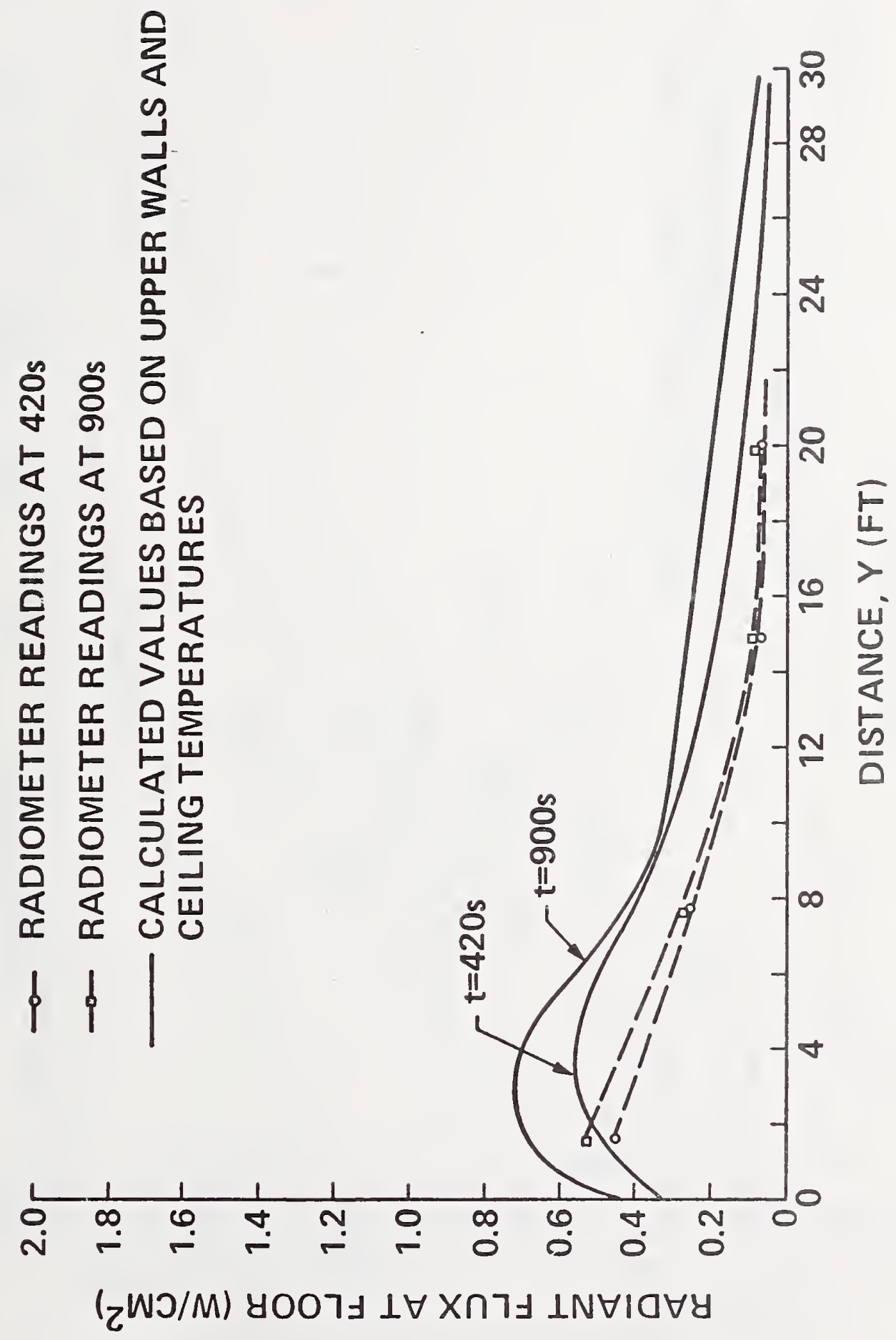

हี 


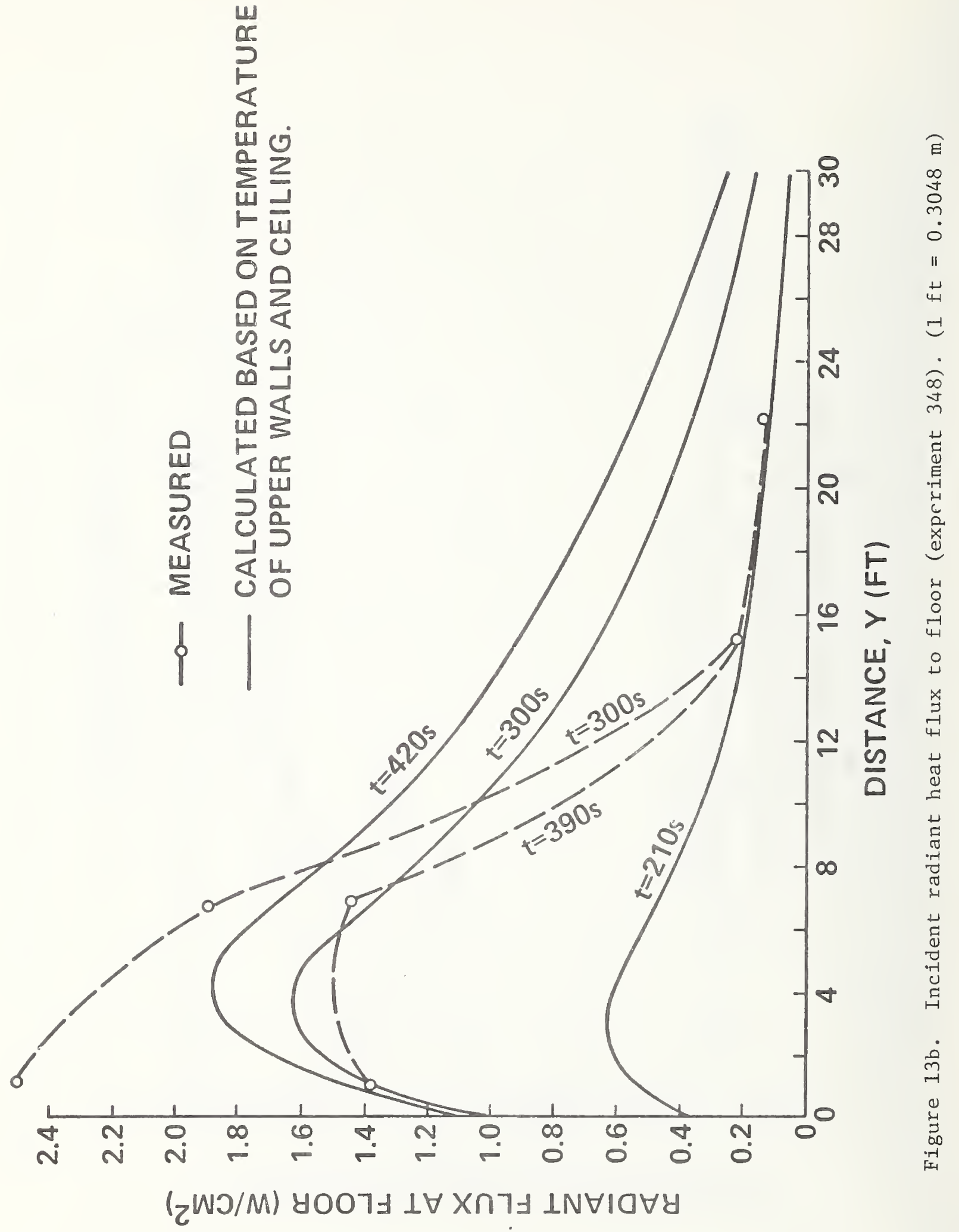




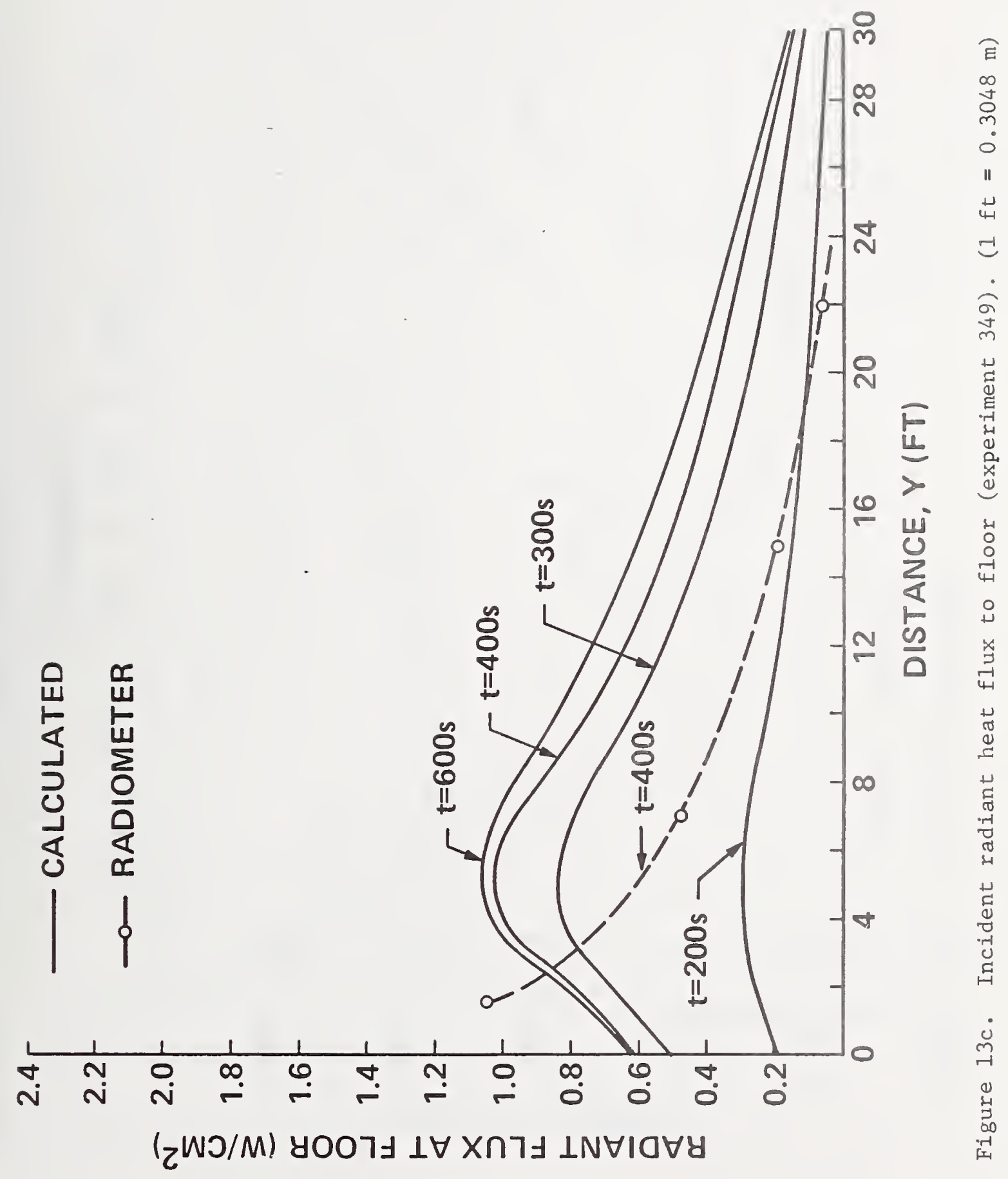




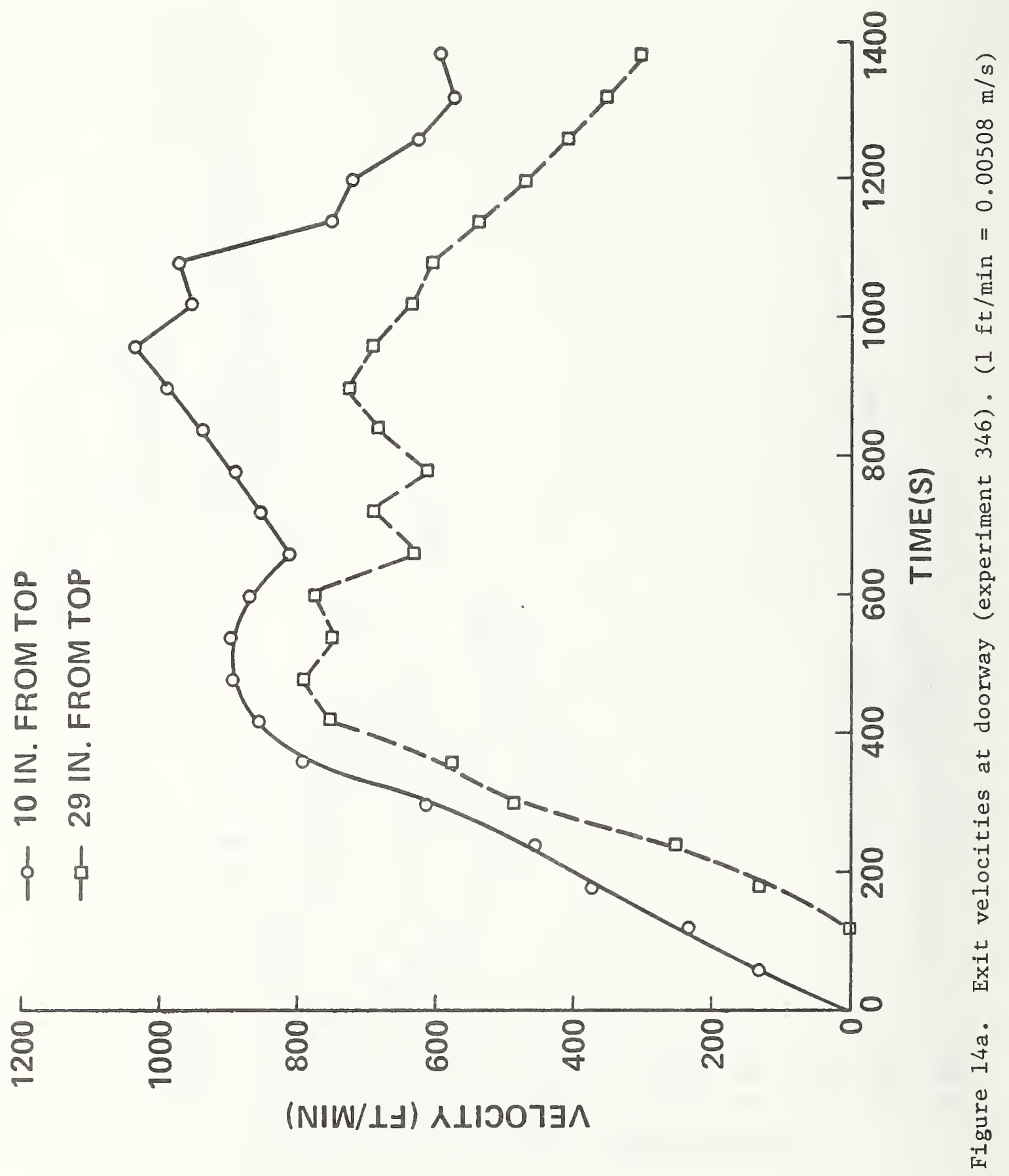




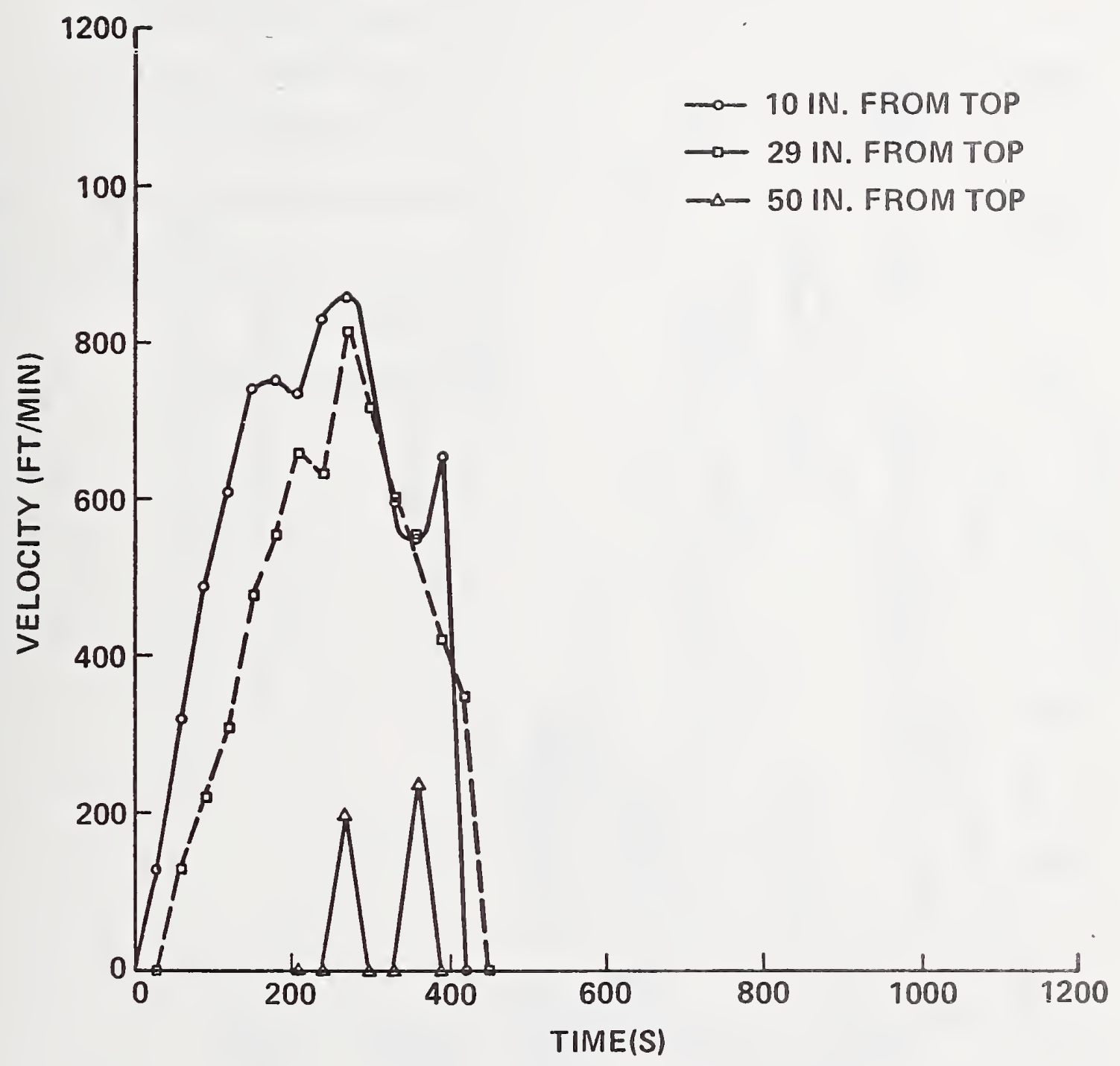

Figure 14b. Exit velocities at doorway (experiment 348$)$. (1 ft/min $=$ $0.00508 \mathrm{~m} / \mathrm{s}$ ) 


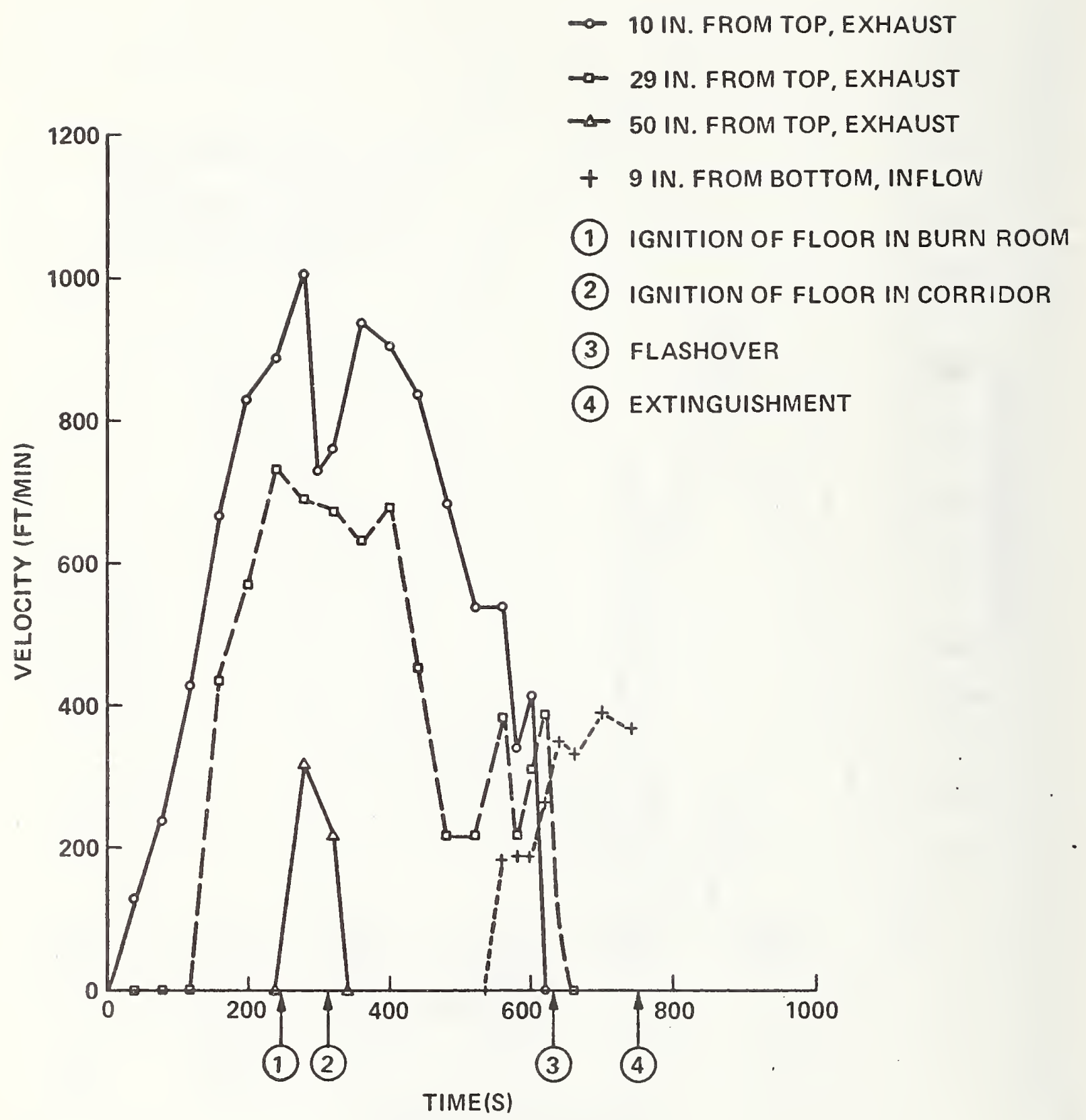

Figure 14c. Exit and inflow velocities at doorway (experiment 349). $(1 \mathrm{ft} / \mathrm{min}=0.00508 \mathrm{~m} / \mathrm{s}$ ) 
(\%) SıJnooyd wooy

JO NOI $\forall Y \perp N \exists J N O J ~ \exists W \cap 7 O \wedge N \exists D \wedge X O$

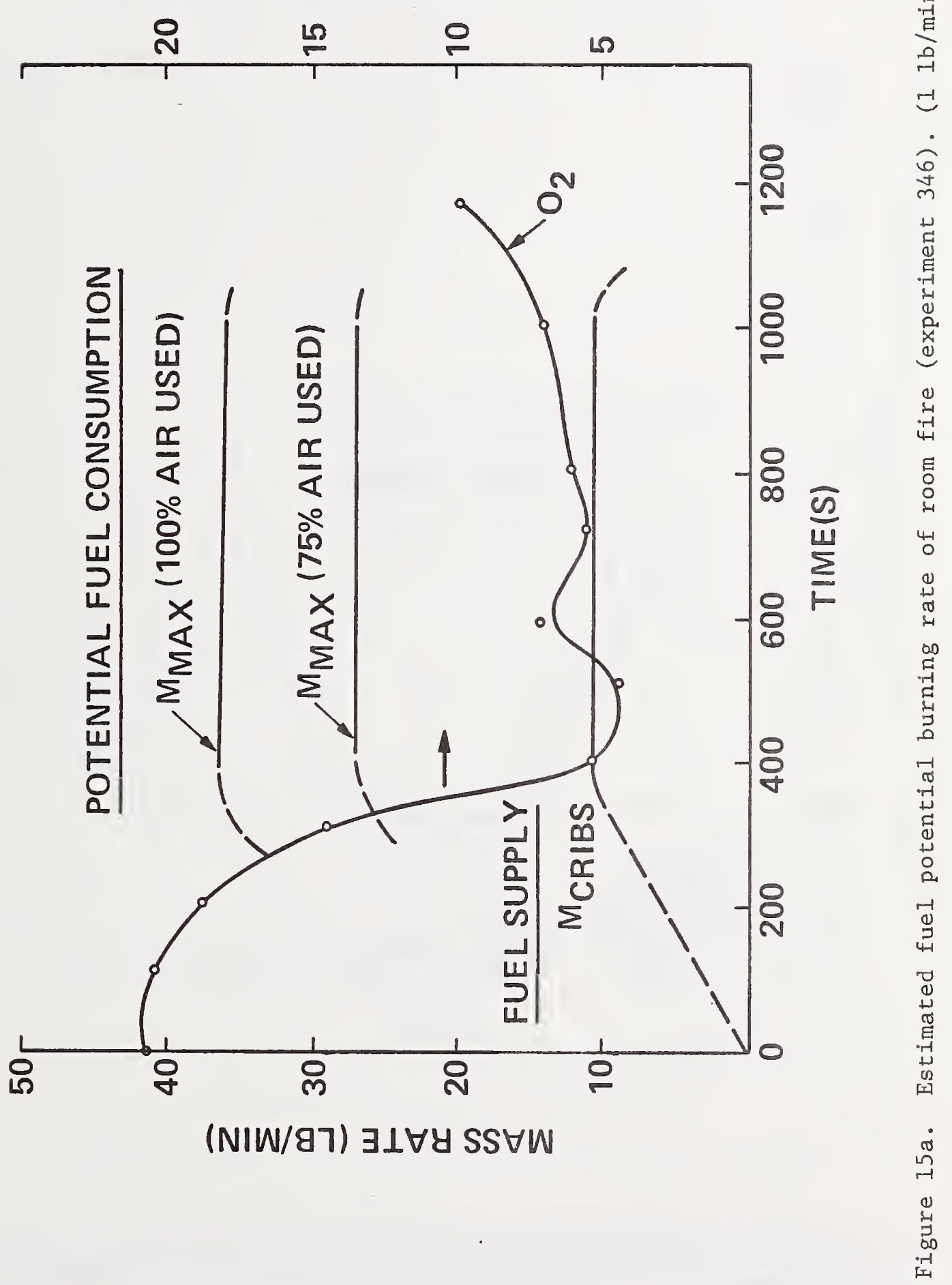




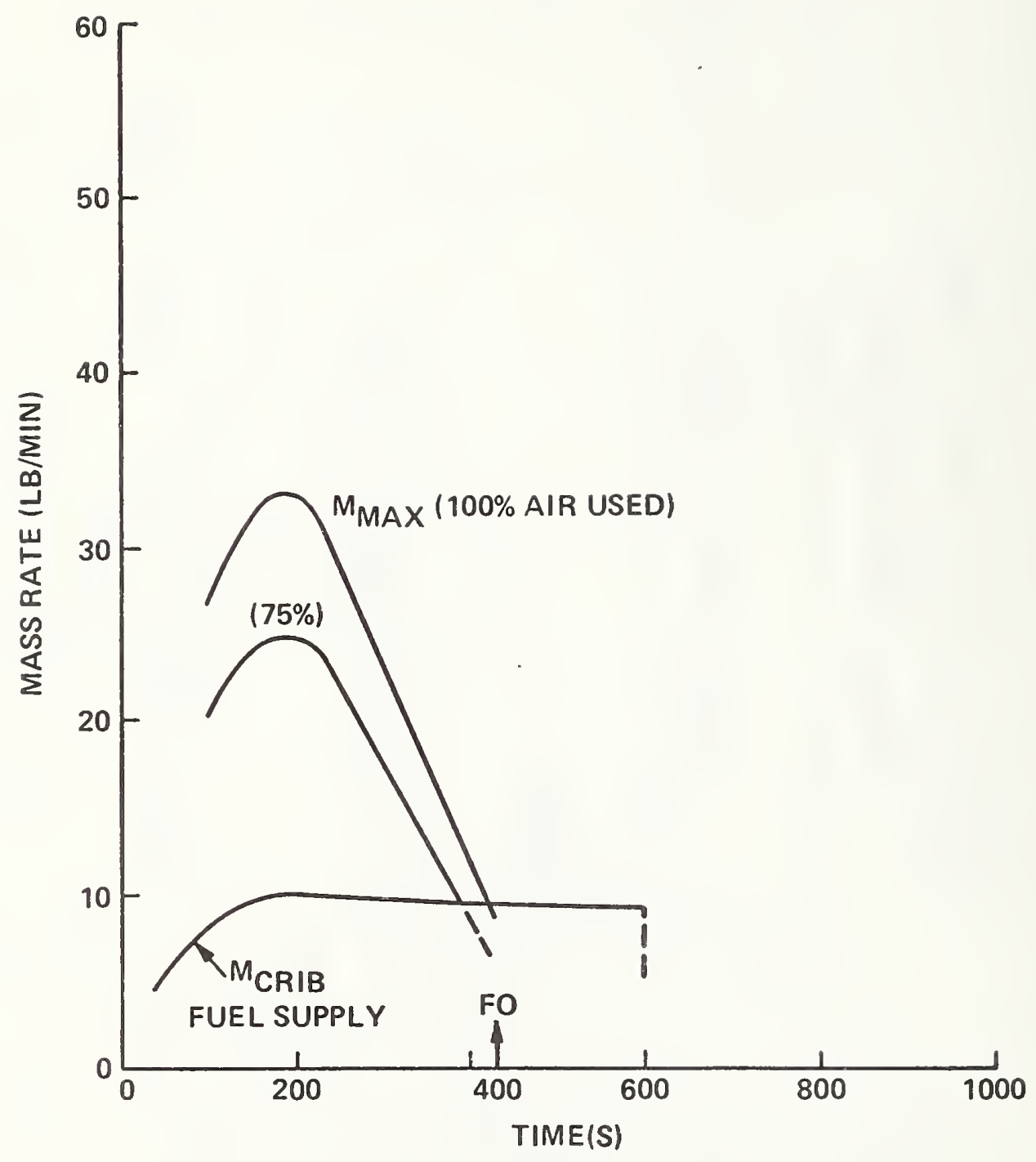

Figure 15b. Estimated fuel potential burning rate of room fire (experiment 348$).(1 \mathrm{lb} / \mathrm{min}=0.00756 \mathrm{~kg} / \mathrm{s})$ 


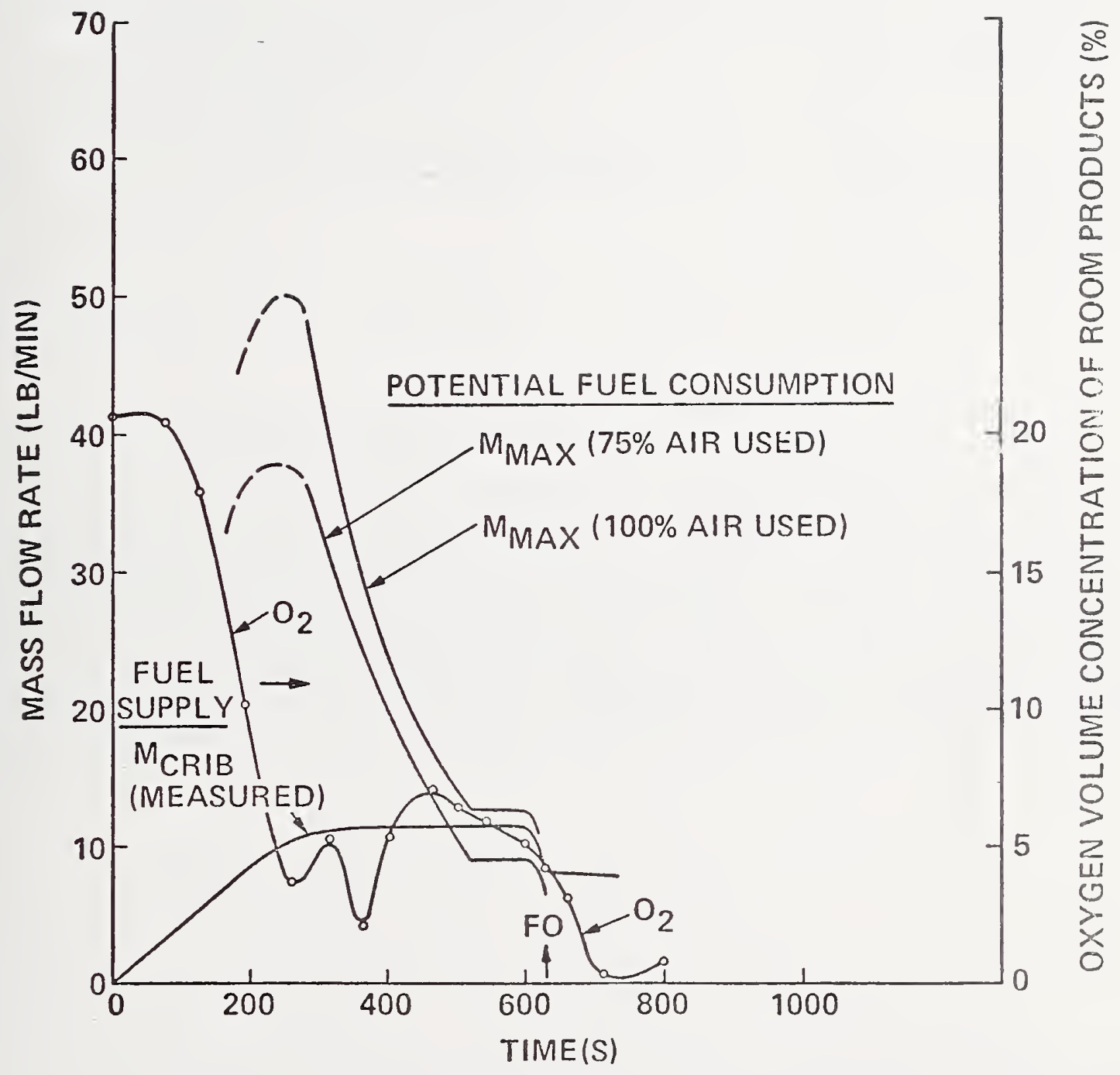

Figure 15c. Estimated fuel potential burning rate of room fire (experiment 349$) \cdot(1 \mathrm{Ib} / \mathrm{min}=0.00756 \mathrm{~kg} / \mathrm{s})$ 


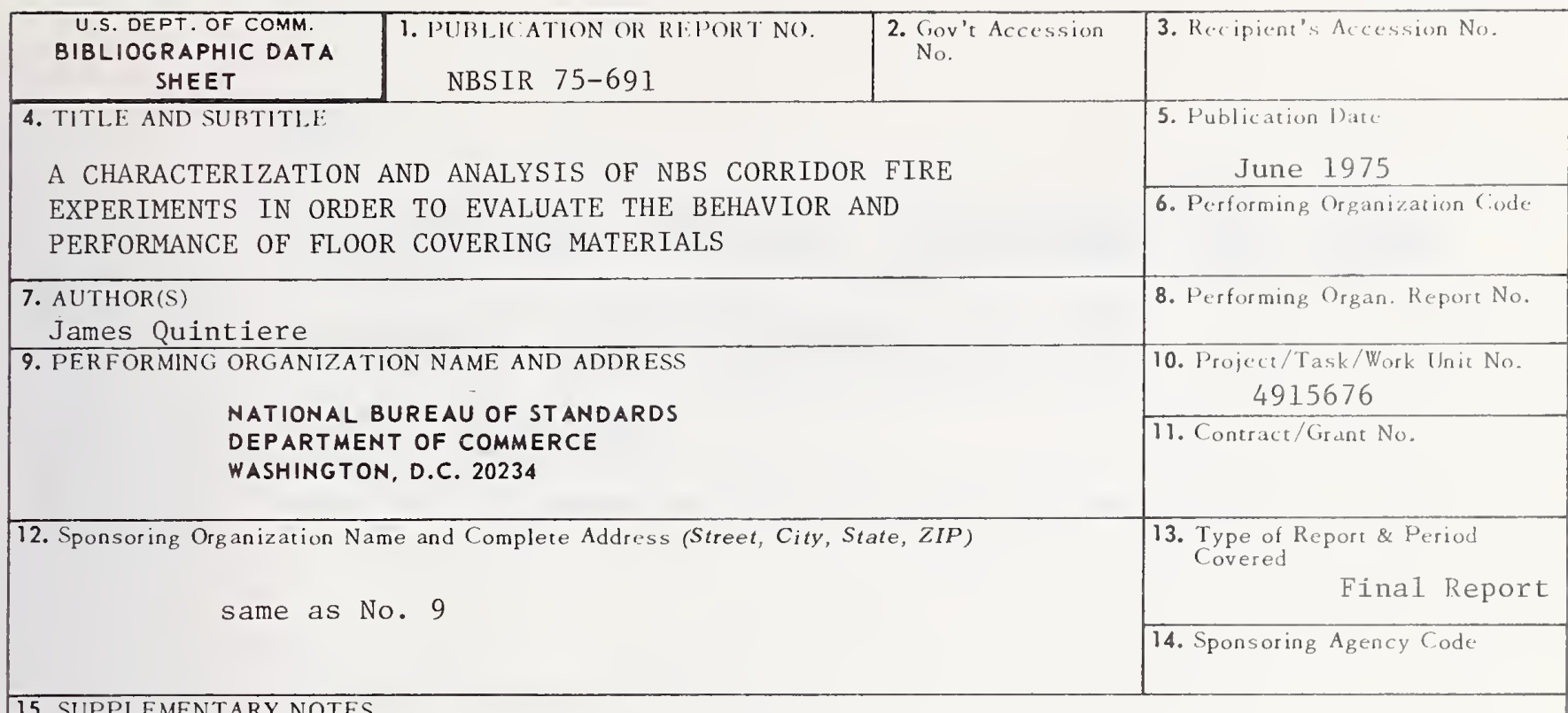

15. SUPPLEMENTARY NOTES

16. ABSTRACT (A 200-word or less factual summary of most significant information. If document includes a significant bibliogtaphy or literature survey, mention it here.)

Data is presented for four fire experiments which examine the fire propagation from a room fire to a floor covering material in a corridor. The four floor covering materials include a nylon and an olefin carpet, vinyl sheet, and red oak flooring. Limited flame spread occurred for the vinyl sheet material; however, the three other materials involved full fire propagation in the corridor. The data are analyzed to examine the factors influencing fire propagation. Included in this analysis is the rate of energy contribution from the room fire and floor covering material, the rate of flame spread, heat transfer to the floor covering, and flow interactions between the room and corridor. A review of previous related experiments is also presented.

17. KEY WORDS (six to twelve entries; alphabetical order; capitalize only the first letter of the first key word unless a proper name; separated by semicolons) Corridor fire spread; energy release rate; fire induced flow; flame propagation; flashover: floor coverings; radiant heat flux.

18. AVAILABILITY Xn Unimited

— For Official Distribution. Do Not Release to NTIS

[ Order From Sup. of Doc., U.S. Government Printing Office Washington, D.C. 20402, SD Cat. No.C13

$\mathrm{X}$ Order From National Technical Information Service (NTIS) Springfield, Virginia 22151

\begin{tabular}{|l|c|}
\hline $\begin{array}{l}\text { 19. SECURITY CLASS } \\
\text { (THIS REPURT) }\end{array}$ & 21. NO. OF PAGES \\
UNCL ASSIFIED & 89 \\
\hline $\begin{array}{l}\text { 20. SECURITY CLASS } \\
\text { (THIS PAGE) } \\
\text { UNCLASSIFILD) }\end{array}$ & 22. PriCe \\
$\$ 4.75$ \\
\hline
\end{tabular}


